Historic, Archive Document

Do not assume content reflects current scientific knowledge, policies, or practices. 



\section{PRICE LIST SPRING 1928}

\section{Henry Kohankie}

\& Son

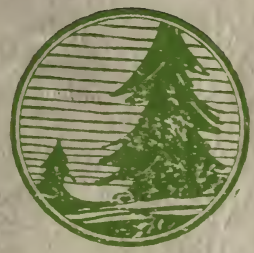

Trees, Shrubs, Evergreens, Vines, Roses, Herbaceous Perennials

\section{PAINESVILLE, OHIO}

Thirty Miles East of Cleveland

Tel. Main 137 



\section{PRICE LIST HENRY KOHANKIE \& SON Spring 1928}

We offer herein a complete list of hardy ornamental nursery stock. Our nursery of five hundred acres affords material to meet practically every need in landscape development. Stock is well grown and supplied with a fibrous root system which is of vital importance in the success of a planting.

All material will be freshly dug. We maintain no storage cellars since the superiority of freshly dug stock is recognized generally.

With few exceptions, the plant names used conform to "Standardized Plant Names" as adopted by the Joint Committee on Horticultural Nomenclature. 



\section{Please Read Carefully!}

\section{CONDITIONS OF SALE}

Stock will be supplied at prices named herein as follows: Five of any one variety at ten rate; twenty-five of any one variety at hundred rate. Prices do not include packing. A charge for the actual cost of the boxes and material used in baling will be made.

Stock specially selected by customers at the nursery will be charged according to its value.

We give no warranty, expressed or implied, as to quality, description, productiveness, or any other matter of any nursery stock that we sell.

We do not guarantee our stock to live and no allowance will be made for plants that fail. Our methods of handling and packing stock are modern and goods will be in good condition and well packed when they leave our grounds. Our responsibility ends upon delivery to carriers. If goods suffer through delay in transit, claim should at once be made on transportation company.

All claims for errors must be made within six days after receipt of goods, or positively will not be considered.

Unknown correspondents who wish to open an account will please give us references and allow us sufficient time to investigate same. Otherwise, cash must accompany order. If goods are desired C. O. D., the order must be accompanied by one third of the amount to guarantee acceptance.

Shipping facilities-We can make direct shipment over the N. Y. C. R. R.; B. \& O. R. R.; N. Y. C. \& St. L. R. R.; American Railway Express and Electric Package. A siding to our packing house direct from the main line of the New York Central railroad enables us to handle stock with a minimum of exposure.

Auto Truck Delivery-We are in a position to make deliveries by auto truck to points within seventy-five miles of Painesville. Charges are made according to the size of truck required and the distance. 



\section{Evergreen Trees}

In this department our stock is thrifty and fibrously rooted, having been several times transplanted. Failure to frequently transplant results in a coarse root system; an evergreen so grown, regardless of how symmetrical and attractive the top may be, is almost certain to give poor results. Prices include lifting the plants with a ball of earth and sewing in burlap as an extra precaution that the plants may arrive in the best of condition.

Abies arizonica. Cork Fir.

each per 10 per 100

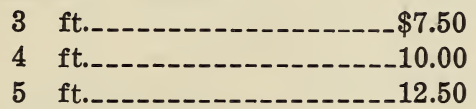

balsamea. Balsam Fir.

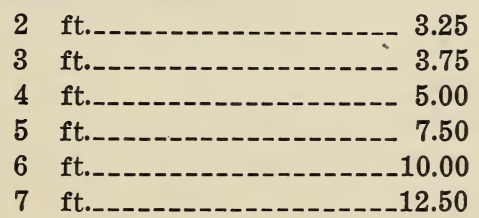

concolor. White Fir.

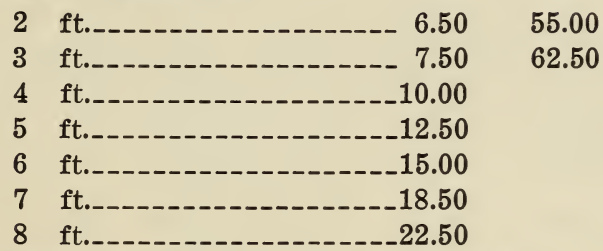

concolor violacea. Purplecone White Fir.

$3 \mathrm{ft}$ 11.00

homolepis. Nikko Fir.

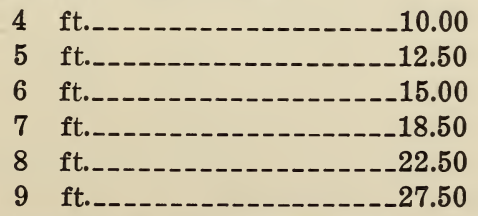

nordmanniana. Nordmann Fir.

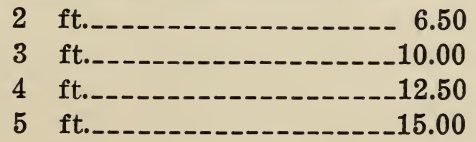


Abies veitchi. Veitch Fir.

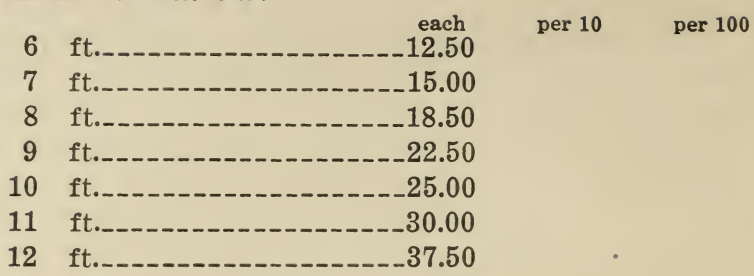

Biota orientalis. (See Thuja.)

Cedrus atlantica glauca. Blue Atlas Cedar.

7 ft.---.-- 15.00

libani. Cedar of Lebanon.

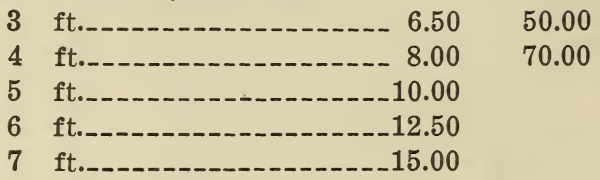

Cephalotaxus fortunei. Chinese Plumyew.

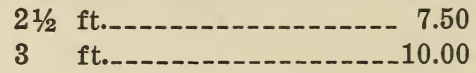

Chamaecyparis lawsoniana. Lawson Cypress.
$3 \mathrm{ft}$. 6.50
55.00
$4 \mathrm{ft}$
8.00
$5 \mathrm{ft}$.
$6 \mathrm{ft}$
12.50

lawsoniana pendula. Weeping Lawson Cypress.
$4 \mathrm{ft}$
$5 \mathrm{ft}$.
$6 \mathrm{ft}$. 18.50

nootkatensis. Nootka Cypress.

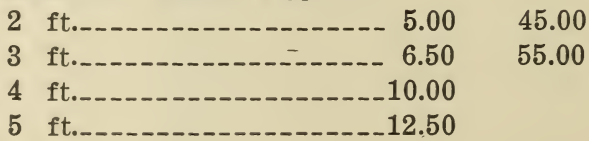

Juniperus chinensis. Chinese Juniper.

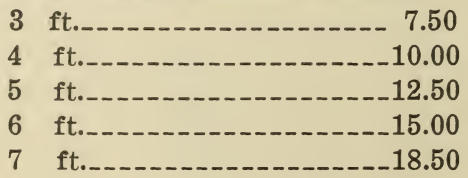


Juniperus chinensis albovariegata.

each

per 10

Whiteleaf Chinese Juniper.

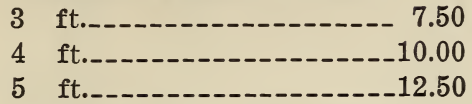

chinensis globosa. Globe Chinese Juniper.
18 in
6.50
55.00
24
10.00

chinensis neaboriensis. Conical Chinese Juniper.

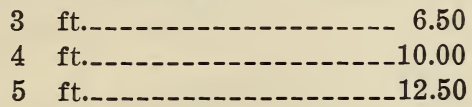

chinensis pfitzeriana. Pfitzer's Juniper.

2 to $2 \frac{1}{2} \mathrm{ft}$. spread__-_-_ $6.50 \quad 60.00$

$21 / 2$ to 3 ft. spread__-_-- $7.50 \quad 70.00$

3 to $3 \frac{1}{2} \mathrm{ft}$. spread_-_._- $10.00 \quad 95.00$

$31 / 2$ to 4 ft. spread__._-_ 12.50

4 to $4 \frac{1}{2} \mathrm{ft}$. spread_-_-_-- 18.50

communis. Common Juniper.

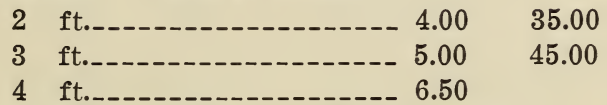

communis depressa. Prostrate Juniper.

18 to 24 in. spread__-_-_ $4.50 \quad 40.00$

24 to 30 in. spread__._- $5.00 \quad 45.00$

$2 \frac{1}{2}$ to $3 \mathrm{ft}$. spread__._-_ $6.50 \quad 50.00$

3 to $4 \mathrm{ft}$. spread__-_.- 7.50

4 to $5 \mathrm{ft}$. spread__-_-_ 10.00

communis depressa aurea.

Golden Prostrate Juniper.

18 to 24 in. spread__-_ $4.50 \quad 40.00$

24 to 30 in. spread_--- $5.00 \quad 45.00$

$2 \frac{1}{2}$ to 3 ft. spread__-_ $6.50 \quad 50.00$

3 to $31 / 2$ ft. spread_-_- $7.50 \quad 65.00$

$31 / 2$ to $4 \mathrm{ft}$. spread_-- $10.00 \quad \mathbf{7 5 . 0 0}$

communis hibernica. Irish Juniper.

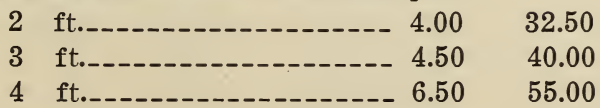

communis kraccovica. Polish Juniper.

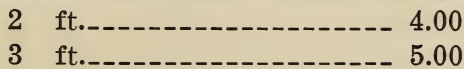


Juniperus communis suecica. Swedish Juniper.

$$
\text { each per } 10 \text { per } 100
$$

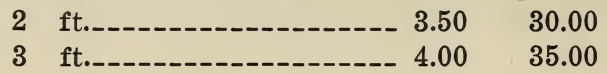

communis suecica nana. Dwarf Swedish Juniper.

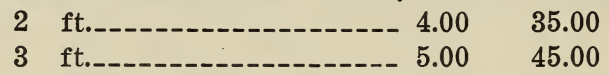

excelsa. Greek Juniper.

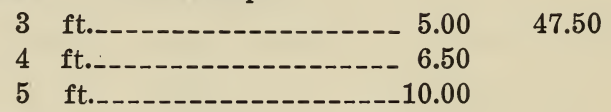

excelsa stricta. Spiny Greek Juniper.

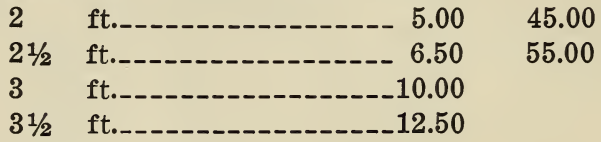

horizontalis. Creeping Juniper.

18 to 24 in. spread_-_--- $4.00 \quad 35.00$

24 to 30 in. spread__-_.- $4.50 \quad 37.50$

$2 \frac{1 / 2}{2}$ to $3 \mathrm{ft}$. spread__-_-- $5.00 \quad 47.50$

horizontalis glauca. Blue Creeping Juniper.

18 to 24 in. spread_-_- $4.00 \quad 35.00$

24 to 30 in. spread_..- $4.50 \quad 40.00$

$21 / 2$ to 3 ft. spread_-_- $5.00 \quad 47.50$

3 to $3 \frac{1 / 2}{\mathrm{ft}}$. spread__-_ $6.50 \quad 55.00$

japonica. Japanese Juniper.

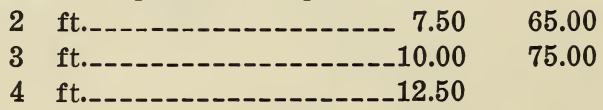

japonica aurea. Golden Japanese Juniper.

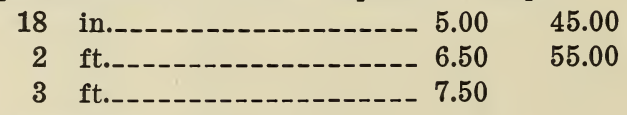

sabina. Savin Juniper.

2 to $2 \frac{1}{2} \mathrm{ft}$. spread_-_-- $\mathbf{5 . 0 0} \quad \mathbf{4 5 . 0 0}$

$21 / 2$ to 3 ft. spread__-_- $6.50 \quad 55.00$

3 to $3 \frac{1}{2} \mathrm{ft}$. spread.---- 7.50

$3 \frac{1}{2}$ to 4 ft. spread_-_-- 10.00

sabina tamariscifolia. Tamarix Savin.

18 to 24 in. spread__._._- 4.50

24 to 30 in. spread_-_-_-- 6.00 


\section{Juniperus}

scopulorum. Colorado Juniper.

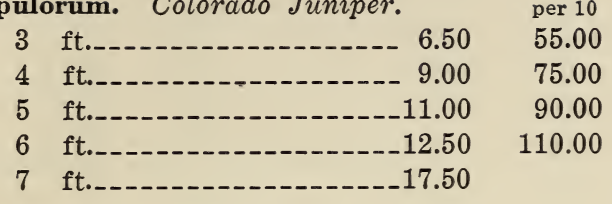

squamata. Japanese Trailing Juniper.

2 to $2 \frac{1 / 2}{\mathrm{ft}}$. spread_-_-_._- 6.50

virginiana. Red Cedar.

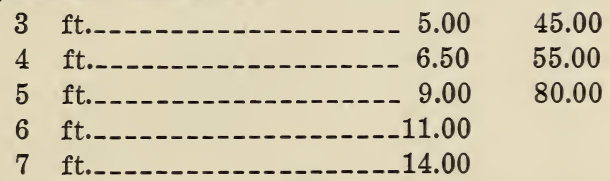

virginiana cannarti. Cannart Red Cedar.

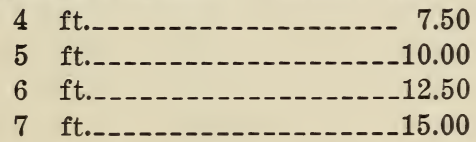

virginiana elegantissima. Goldtip Red Cedar.

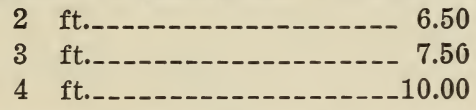

virginiana glauca. Silver Red Cedar.

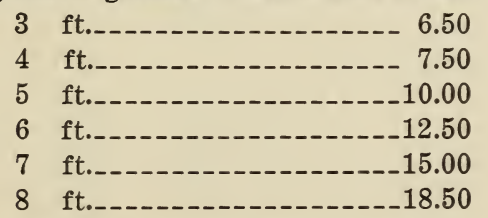

virginiana kosteri. Koster Red Cedar.

2 to $2 \frac{1}{2} \mathrm{ft}$. spread__._.- 7.50

$21 / 2$ to $3 \mathrm{ft}$. spread._-_- 10.00

3 to $31 / 2$ ft. spread___-_- 12.50

virginiana schotti. Schott Red Cedar.

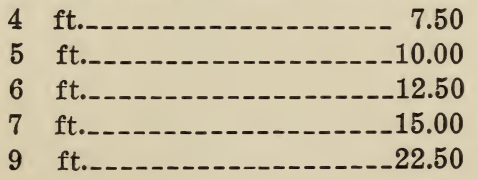


Picea alba. White Spruce.

each per 10

per 100

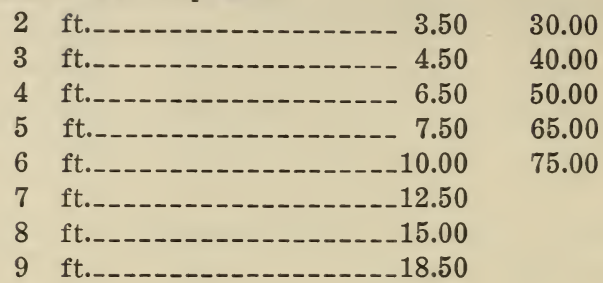

alcockiana. Alcock Spruce.

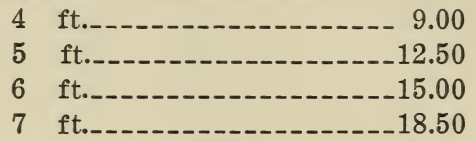

canadensis. Black Hills Spruce.

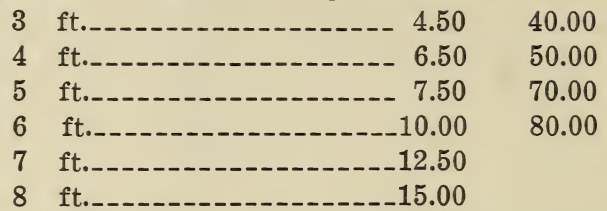

engelmanni. Englemann Spruce.

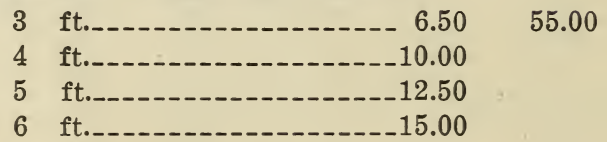

excelsa. Norway Spruce.

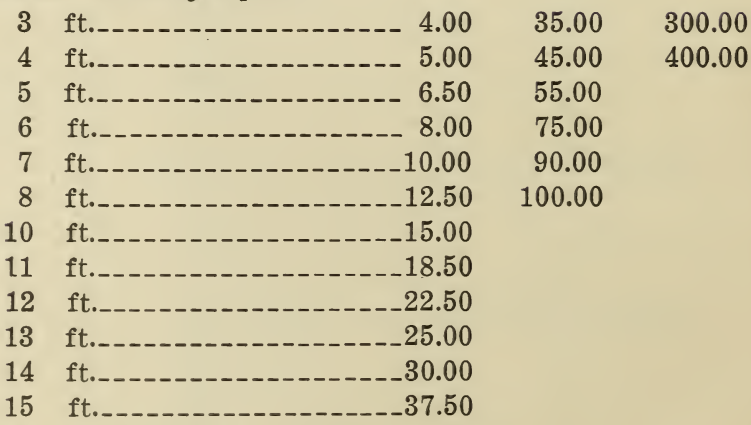

excelsa aurea. Golden Norway Spruce.

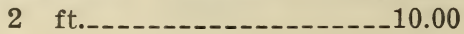




\section{Picea}

excelsa pendula. Weeping Spruce.

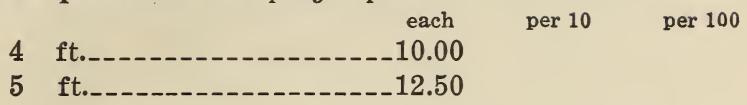

excelsa maxwelli. Maxwell Spruce.

18 to 24 in.-_-_-_-_-_-_ 10.00

24 to 30 in._-_._-_._-_ 12.50

excelsa nana compacta. Dwarf Spruce.

18 to 24 in.--_-_-_-_-_ 10.00

24 to 30 in..-_-_-_-_-_-_ 12.50

excelsa pygmea. Pygmy Norway Spruce.

15 to 18 in..._-_._-_._- 7.50

18 to 24 in........- 10.00

excelsa remonti. Remont Spruce.

18 to 24 in.._..._- 10.00

24 to 30 in._-_-_-_-_-_-_-_ 12.50

mariana. Black Spruce.

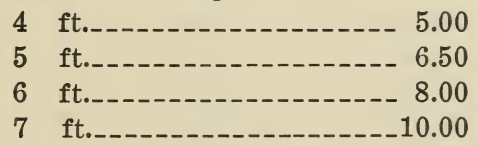

orientalis. Oriental Spruce.

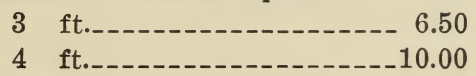

polita. Tigertail Spruce.

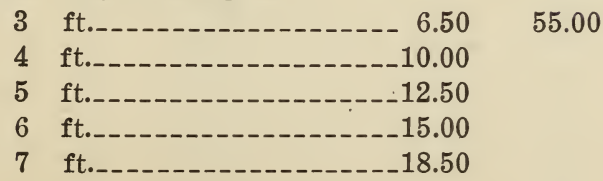

pungens. Colorado Spruce.

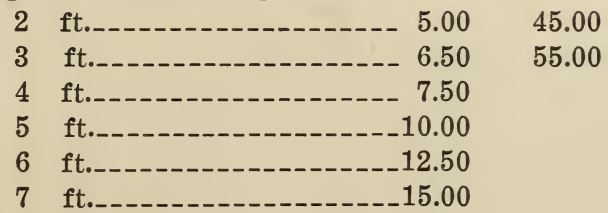




\section{Picea}

pungens glauca. Blue Colorado Spruce.

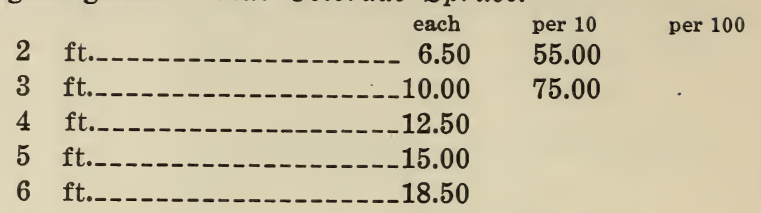

pungens kosteri. Koster Blue Spruce.

\begin{tabular}{|c|c|}
\hline $21 / 2$ & ft._- \\
\hline 3 & ft.._- \\
\hline $31 / 2$ & ft.-_- 18.50 \\
\hline 4 & ft..- \\
\hline $41 / 2$ & ft._- \\
\hline 5 & ft._- \\
\hline $51 / 2$ & ft._- 30.00 \\
\hline 6 & ft._- \\
\hline 7 & ft._- \\
\hline 9 & ft. specimens_-_-_-- 62.50 \\
\hline 10 & ft. specimens_-_-_- 70.00 \\
\hline 11 & ft. specimens_-_- 75.00 \\
\hline 12 & ft. specimens__-__- 80.00 \\
\hline 13 & ft. specimens_-_-_-_90.00 \\
\hline & ft. specimens_-_- 110.00 \\
\hline
\end{tabular}

Pinus austriaca. (See Pinus Nigra.)

banksiana. Jack Pine.

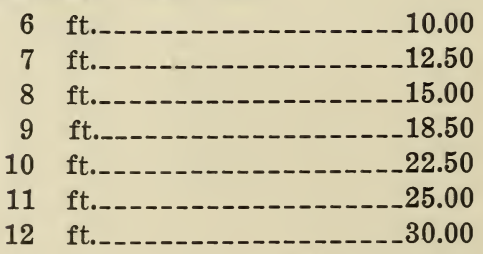

densiflora. Japanese Red Pine.

6 ft._-_-_-_._- 12.50

7 ft.-_-_-_-_-_- 15.00

8 ft.-_-_.

9 ft._-_-_-_-_-_-_-_-_-_. 25.00 


\section{Pinus.}

flexilis. Limber Pine.

$$
\text { each }
$$

per 10

per 100

$4 \mathrm{ft}$. 6.50 50.00

$5 \mathrm{ft}$. 7.50 65.00

$6 \mathrm{ft}$ 10.00

7 12.50

$8 \mathrm{ft}$. 15.00

montana. Swiss Mountain Pine.

$\begin{array}{lll}21 / 2 & \text { to } 3 & \mathrm{ft} . \\ 3 & \text { to } 31 / 2 & \mathrm{ft} . \\ 31 / 2 & \text { to } 4 & \mathrm{ft}\end{array}$

montana mughus. Dwarf Mountain Pine.

18 to 24 in. spread_-_- $5.00 \quad 45.00$

2 to $21 / 2 \mathrm{ft}$. spread__.- $6.50 \quad 55.00$

$21 / 2$ to 3 ft. spread__-_ $7.50 \quad 65.00$

3 to $31 / 2 \mathrm{ft}$. spread_-_ 10.00

$31 / 2$ to 4 ft. spread__-_ 12.50

nigra. Austrian Pine.

3 ft._._-_._- 6.50

55.00

4 ft._._._. 7.50

5 ft._._.

5 ft. specimens_._-_._-_ 12.50

$6 \mathrm{ft}$. specimens

$7 \mathrm{ft}$. specimens_._._._._- 18.50

$8 \mathrm{ft}$. specimens_._._._-_._. 22.50

$9 \mathrm{ft}$. specimens_-_-_-_- 25.00

$10 \mathrm{ft}$. specimens

$11 \mathrm{ft}$. specimens_____-_-_37.50

$12 \mathrm{ft}$. specimens ponderosa. Western Yellow Pine.

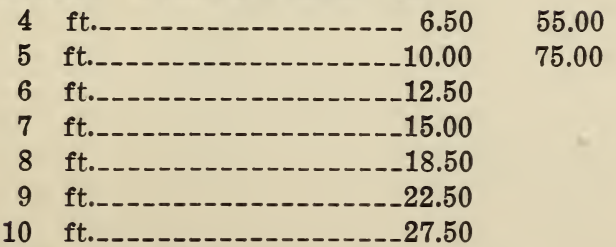

resinosa. Red Pine.

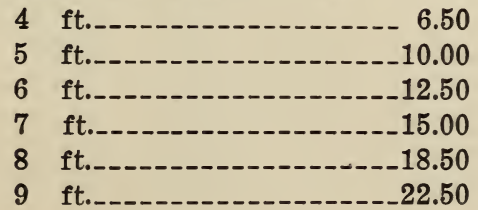




\section{Pinus}

\begin{tabular}{|c|c|c|c|}
\hline strobus & - White Pine. each & per 10 & per 100 \\
\hline 4 & ft.-.- 6.50 & 55.00 & \\
\hline 5 & ft._-_- 7.50 & 70.00 & \\
\hline 6 & ft..- 10.00 & 75.00 & \\
\hline 7 & ft._- & 100.00 & \\
\hline 8 & ft.._- 15.00 & & \\
\hline 9 & ft._- 18.50 & & \\
\hline 10 & ft._. & & \\
\hline 11 & ft._-_- & & \\
\hline 12 & ft. specimens_-__- 32.50 & & \\
\hline 13 & ft. specimens__-_- 37.50 & & \\
\hline 14 & ft. specimens___-__- 45.00 & & \\
\hline 15 & ft. specimens_______ 50.00 & & \\
\hline
\end{tabular}

sylvestris. Scotch Pine.

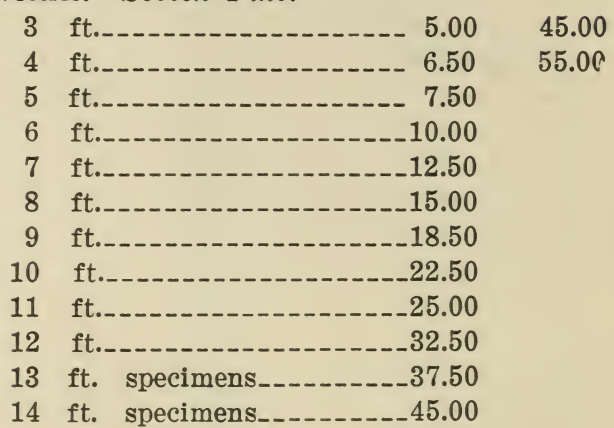

thunbergi. Japanese Black Pine.
8 ft._._._._._. 18.50

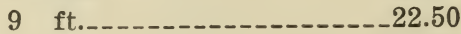
10 ft.
11 ft. specimens_______-_32.50
12 ft. specimens________ 37.50

Pseudotsuga douglasi. Douglas Fir.

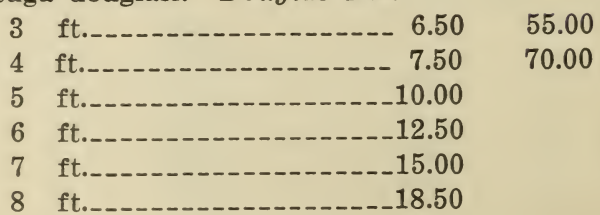


each per 10 per 100

Retinospora filifera. Thread-branched Japanese Cypress.

\begin{tabular}{|c|c|}
\hline 2 & ft._- 6.00 \\
\hline 3 & ft...- 7.50 \\
\hline 4 & ft. specimens__-__- 12.50 \\
\hline & specimens_-_- \\
\hline & ft. specimens_-_- \\
\hline
\end{tabular}

\section{filifera aurea.}

Golden Thread-branched Japanese Cypress.

18 in. spread._._._._- $6.00 \quad 50.00$

24 in. spread__._._._. $6.50 \quad 55.00$

30 in. spread_-_-_-_-_-_- 7.50

36 in. spread specimens_-- 12.50

\section{filifera aurea nova.}

Variegated Thread-branched Japanese Cypress.

18 to 24 in. spread._...-.- $6.00 \quad 50.00$

24 to 30 in. spread__._._.- $6.50 \quad 55.00$

30 to 36 in. spread._.....- 10.00

obtusa compacta. Compact Hinoki Cypress.

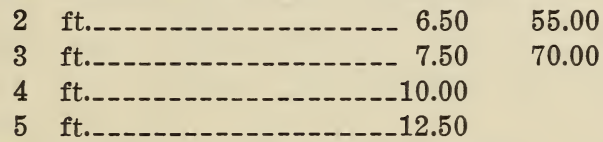

obtusa crippsi. Yellow Hinoki Cypress.
2 ft._._._-_._. $5.00 \quad 45.00$
3 ft._._-_._- 10.00
4 ft.-_-_-_- 12.50

obtusa gracilis. Slender Hinoki Cypress.

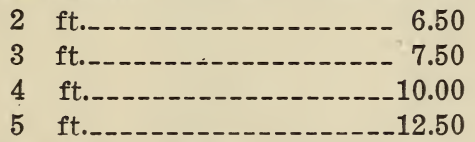

obtusa nana. Dwarf Hinoki Cypress.

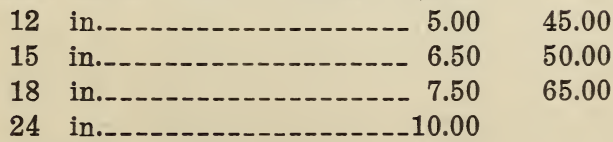

pisifera. Sawara Cypress.

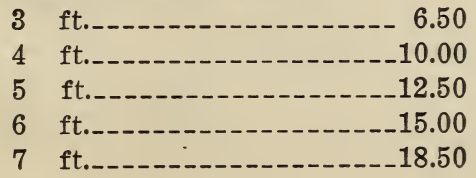


Retinospora pisifera aurea.

Golden Sawara Cypress. each

3 ft.--_-_-_-_-_-_-_-_-_ 6.50

per 10

per 100

$4 \mathrm{ft}$.

8.00

50.00

$5 \mathrm{ft}$

10.00

75.00

$6 \mathrm{ft}$. specimens

90.00

7 ft. specimens

15.00

125.00

8 ft. specimens

18.50

9 ft. specimens

22.50

$10 \mathrm{ft}$. specimens

plumosa. Plume Cypress.

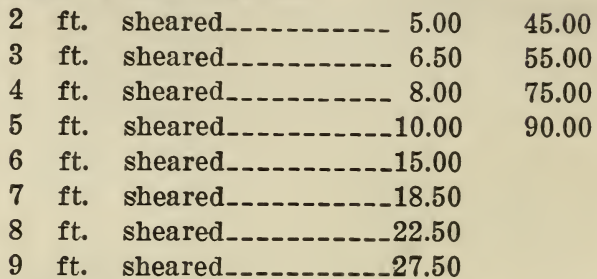

$3 \mathrm{ft}$. high $\times 4 \mathrm{ft}$. spd. extra spec. 12.50

$4 \mathrm{ft}$. high $\times 5 \mathrm{ft}$. spd. extra spec. 18.50

$5 \mathrm{ft}$. high $\times 6 \mathrm{ft}$. spd. extra spec. 25.00

plumosa aurea. Goldenplume Cypress.

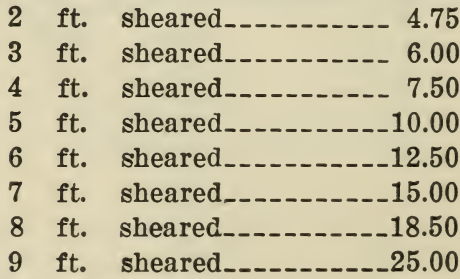

$2 \mathrm{ft}$. high $\times 3 \mathrm{ft}$. spd. extra spec. 10.00

$3 \mathrm{ft}$. high $\times 4 \mathrm{ft}$. spd. extra spec. 12.50

$4 \mathrm{ft}$. high $\times 5 \mathrm{ft}$. spd. extra spec. 18.50

$5 \mathrm{ft}$. high $\times 6 \mathrm{ft}$. spd. extra spec. 25.00

plumosa argentea. Silvertip Cypress.

2 ft._._- 3 ft._-_.

plumosa lutescens. (Globe form.)

24 in.-_-_-_._- 6.50

30 in.--10.00

36 in. 


\section{Retinospora.}

plumosa sulphurea. Sulphurplume Cypress.

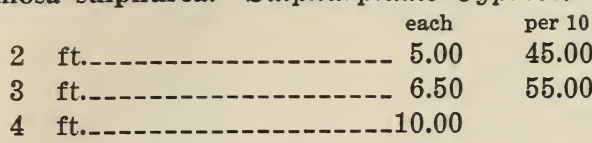

squarrosa. Moss Retinospora.

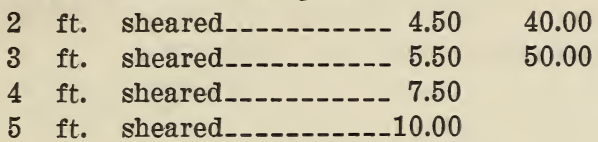

Sciadopitys verticillata. Umbrella Pine.

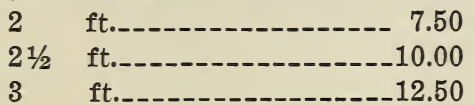

Taxus baccata. English Yew.

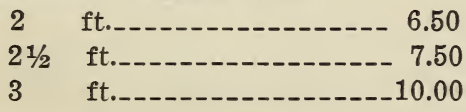

baccata erecta. Broom Yew.

18 in.--_.-- 10.00

baccata fastigiata. Irish Yew.

18 in.-.-.-- 10.00

$2 \mathrm{ft.}$.

baccata repandens. Spreading English Yew.

18 to 24 in. spread__._.-. 6.00

baccata washingtoni. Washington Yew.

18 in..-_-_-_.-.- $5.00 \quad 40.00$

24 in.-_-_-_-_- $6.50 \quad 50.00$

canadensis. Canada Yew.

18 to 24 in. spread

2 to $2 \frac{1}{2} \mathrm{ft}$. spread.... 5.00

$21 / 2$ to $3 \mathrm{ft}$. spread...- 6.00

cuspidata. Japanese Yew.

2 to $2 \frac{1}{2} \mathrm{ft}$. spread_-_- 6.50

$21 / 2$ to 3 ft. spread.-.- 7.50

3 to $3 \frac{1}{2} \mathrm{ft}$. spread_..- 10.00

$31 / 2$ to 4 ft. spread_--- 12.50

cuspidata brevifolia. Dwarf Japanese Yew.

18 to 24 in....... 7.50

24 to 30 in.............. 10.00 


\section{Taxus}

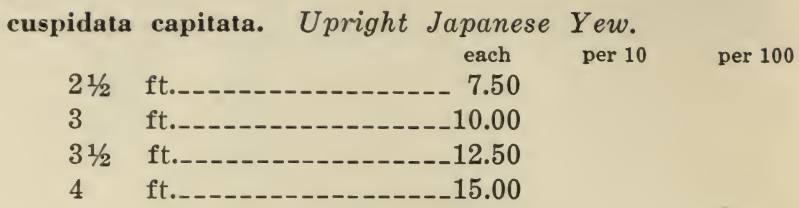

Thuja occidentalis. American Arborvitae.

\begin{tabular}{|c|c|}
\hline 3 & 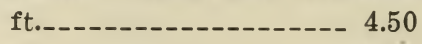 \\
\hline 4 & ft.r--10- 6.00 \\
\hline 4 & ft. heavy specimens_-- 10.00 \\
\hline 5 & ft.-_- 8.00 \\
\hline 5 & ft. heavy specimens_-- 12.50 \\
\hline 6 & ft._- \\
\hline 6 & ft. heavy specimens_-- 15.00 \\
\hline 7 & ft._-_- 12.50 \\
\hline 7 & ft. heavy specimens_-_ 18.50 \\
\hline 8 & ft.-_- \\
\hline 8 & ft. heavy specimens_-_22.50 \\
\hline 9 & ft.-_- \\
\hline 9 & ft. heary specimens_-_27.50 \\
\hline 10 & ft. heavy specimens_-- 32.50 \\
\hline & ft. heavy specimens_-_ 37.50 \\
\hline
\end{tabular}

occidentalis aurea douglasi. Douglas Golden Arborvitae

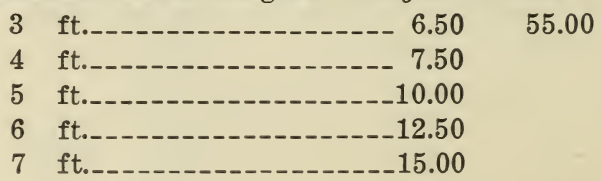

occidentalis columbia. Silver-tipped Arborvitae.

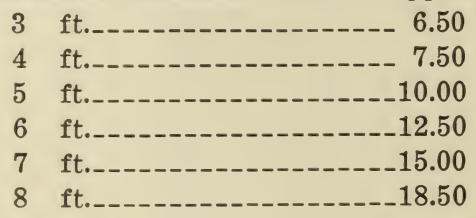

occidentalis compacta. Compact Arborvitae.

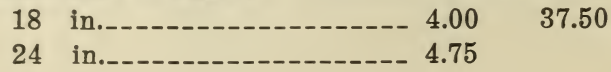


Thuja

occidentalis compacta. Parsons Arborvitae.

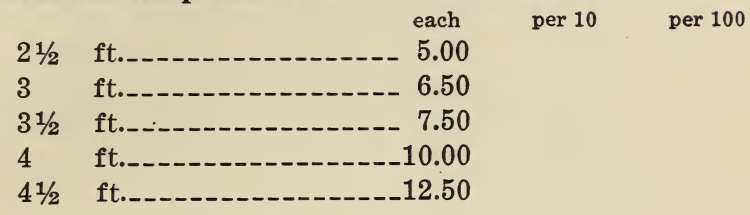

occidentalis elegantissima.

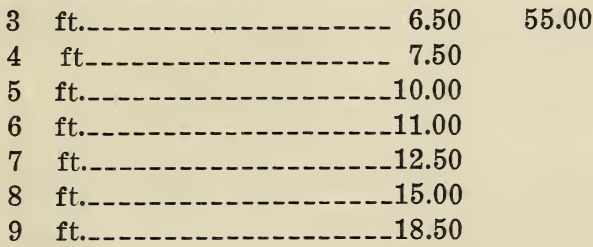

occidentalis ellwangeriana. Tom Thumb Arborvitae.

\begin{tabular}{|c|c|}
\hline & ft.-.-n 3.00 \\
\hline $1 / 2$ & - \\
\hline & ft._._- \\
\hline
\end{tabular}

occidentalis ericoides. Heath Arborvitae.

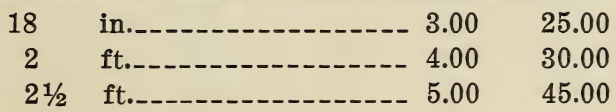

occidentalis globosa. Globe Arborvitae.

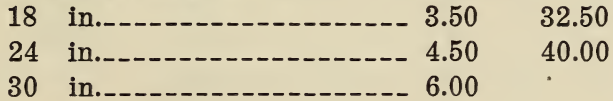

occidentalis hoveyi. Hovey Golden Arborvitae.

\begin{tabular}{|c|c|}
\hline 18 & in.... 3.50 \\
\hline 2 & ft._-n- 4.00 \\
\hline $21 / 2$ & ft.r-nos 5.00 \\
\hline 3 & ft._- 6.50 \\
\hline $31 / 2$ & ft._-1- \\
\hline 4 & ft._-_- \\
\hline $41 / 2$ & ft. \\
\hline 5 & ft.-_- \\
\hline $51 / 2$ & ft. \\
\hline
\end{tabular}


Thuja

occidentalis lutea. Geo. Peabody's Arborvitae.

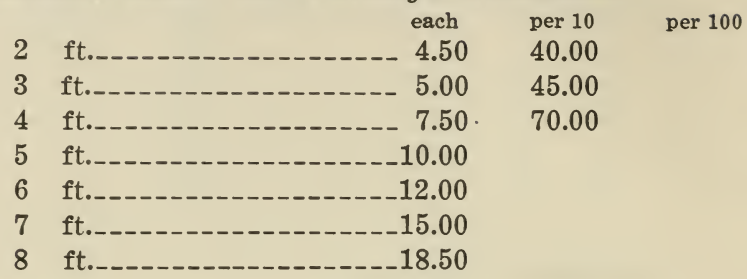

occidentalis pumila. Green Globe Arborvitae.

18 in. spread._._-_._- 4.00

24 in. spread__-_-_-_-_ 5.00

occidentalis pyramidalis. Pyramidal Arborvitae.

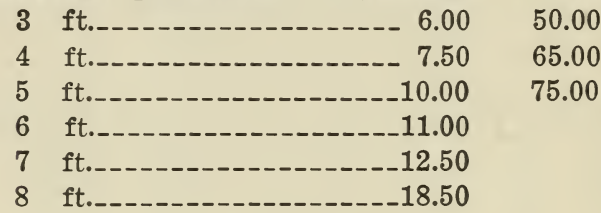

occidentalis douglasi pyramidalis.

Douglas Pyramidal Arborvitae.

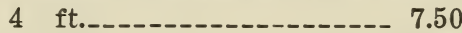

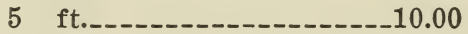

6 ft........... 12.50

occidentalis reevesi. Reeves Arborvitae.

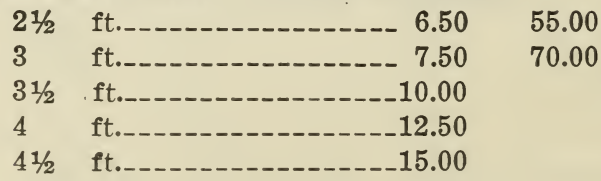

occidentalis reidi. Reid Arborvitae.

\begin{tabular}{|c|c|}
\hline 8 & in.--n 4.00 \\
\hline 2 & 5.00 \\
\hline $21 / 2$ & 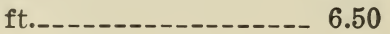 \\
\hline
\end{tabular}

occidentalis riversi. Rivers Arborvitae.

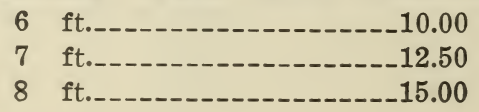


Thuja occidentalis rosenthali. Rosenthal Arborvitae.

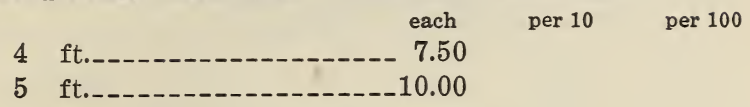

occidentalis spiralis. Spiral Arborvitae.

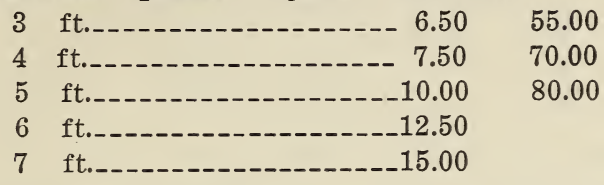

occidentalis umbraculifera. Dwarf Arborvitae.

$\begin{array}{cllll}18 & \text { to } 24 & \text { in. spread__-_ } 4.00 & 35.00 \\ 24 & \text { to } 30 & \text { in. spread_-_-- } 5.00 & 47.50 \\ 21 / 2 & \text { to } 3 & \text { ft. spread_--- } 6.50 & \\ 3 & \text { to } 31 / 2 & \text { ft. } \text { spread_-_- } 10.00 & \end{array}$

occidentalis vervaeneana. Vervaene Arborvitae.

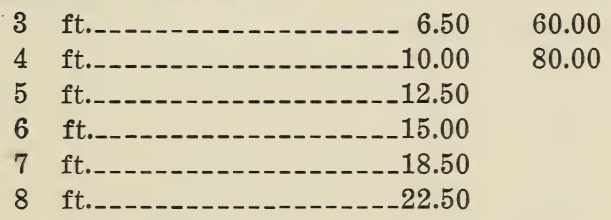

occidentalis wareana. Ware or Siberian Arborvitae.

\begin{tabular}{|c|c|c|}
\hline 18 & in. & 35.00 \\
\hline 2 & ft.-_-n-- & 40.00 \\
\hline $21 / 2$ & ft.r-son 5.00 & 45.00 \\
\hline 3 & ---6.50 & 55.00 \\
\hline $31 / 2$ & ft.--1-1- 7.50 & 70.00 \\
\hline 4 & ft. & \\
\hline $41 / 2$ & - & \\
\hline
\end{tabular}

occidentalis wareana lutescens. Golden Ware Arborvitae.

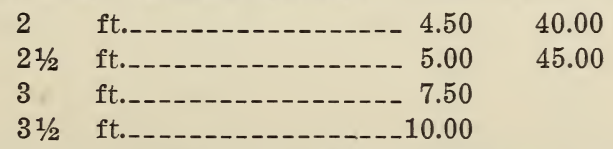

occidentalis woodwardi. Woodward Arborvitae.

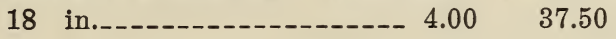

orientalis. Oriental Arborvitae.

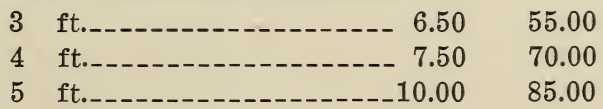




\section{Thuja}

orientalis. Oriental Arborvitae.

\begin{tabular}{|c|c|c|}
\hline & each & per 10 \\
\hline 6 & ft. & 100.00 \\
\hline 7 & ft. & \\
\hline 8 & ft._-_- & \\
\hline 9 & ft._- & \\
\hline & ft._- & \\
\hline & ft._-_- & \\
\hline
\end{tabular}

orientalis elegantissima. Rollinson's Golden Arborvitae.

$5 \mathrm{ft}$.

$6 \mathrm{ft}$

orientalis nana aurea.

Berkmans Golden Arborvitae.

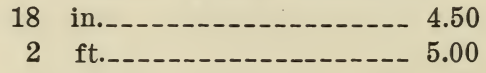

plicata. Giant Arborvitae.

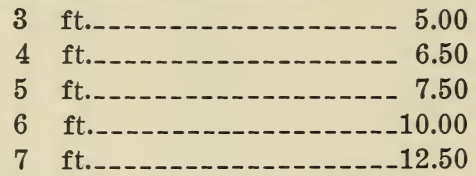

standishi. Standish Arborvitae.

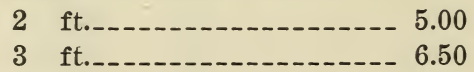

Tsuga canadensis. Canada Hemlock.

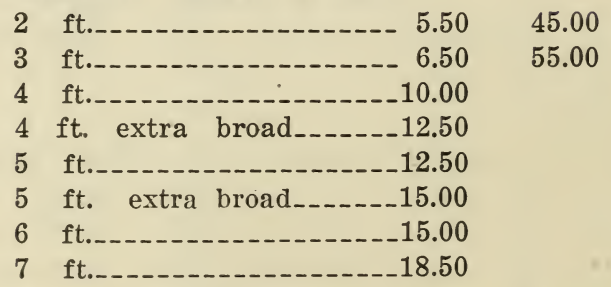

canadensis pendula. Sargent Weeping Hemlock.

2 to 3 ft. spread____._10.00

sieboldi. Siebold Hemlock.

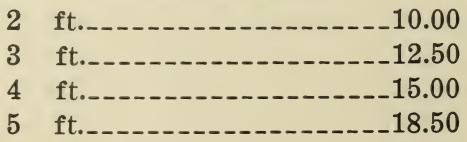




\section{Evergreen Shrubs}

Andromeda floribunda. Mountain Andromeda.

18 to 24 in._-_-_-_B. \& B. $\begin{array}{llrr}\text { each } & \text { per } 10 & \text { per } 100 \\ & & 32.50 & 280.00\end{array}$

Azalea amoena. Amoena Azalea.

12 to 15 in._-_-_-_B. \& B. 2.75

15 to 18 in.-_-_-_-_B. \& B. 3.50

hinodegiri. Carmine Azalea.

12 to 15 in..-_-_-_B. \& B. 3.25

15 to 18 in.-------_B. \& B. 3.75

ledifolia. Snow Azalea.

12 to 15 in._-_B. \& B. 2.00

15 to 18 in._-__-_B. \& B. 2.50

yodogawa. Yodogawa Azalea.

12 to 15 in.-_-_B. \& B. 2.00

15 to 18 in._-_-_B. \& B. 2.50

Calluna vulgaris alba. Heather.

6 to 8 in., 5 in. pots.----- $1.25 \quad 10.00$

vulgaris alporti. Alport Heather.

4 inch pots --.--_----- $1.25 \quad 10.00$

vulgaris carnea. Flesh Heather.

6 to 8 in., 5 inch pots_-_- $1.25 \quad 10.00$

Crataegus pyracantha lelandi. Leland Firethorn.

18 to 24 in. bushy_-B. \& B. $3.25 \quad 27.50$

2 to 3 ft. bushy_-B. \& B. $3.75 \quad 32.50$

12 to 15 in., 4 in. pots_-_-- $1.25 \quad 10.00$

Daphne cneorum. Garland Flower.

8 to 10 in. spread_-_-_-_ $1.25 \quad 11.00$

10 to 12 in. spread__-_-_-_ $2.00 \quad 16.00$

Euonymus nanus. Dwarf Burningbush.

18 to 24 in.-_.- $65 \quad 5.00$

40.00

radicans Wintercreeper.

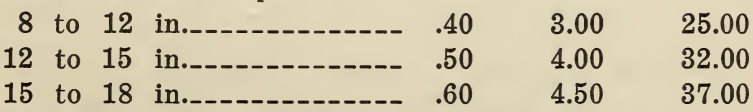

radicans acutus. Sharpleaf Wintercreeper.

12 to 15 in.-_-_-_-_. $.50 \quad 4.00 \quad 35.00$

15 to 18 in.-_-_-_-_-- $.60 \quad 5.00 \quad 45.00$

radicans argenteo-marginatus. Silveredge Wintercreeper.

8 to 12 in.-_-_-_-_-_-_.-. $.40 \quad 3.00 \quad 25.00$

12 to 15 in.------------- $.50 \quad 4.00 \quad 32.00$

15 to 18 in..-_.-. $60 \quad 4.50 \quad 37.00$ 


\section{Euonymus}

radicans carrieri. Glossy Wintercreeper.

$\begin{array}{rrrrr} & & \text { each } & \text { per } 10 & \text { per } 100 \\ 12 & \text { to } 15 \text { in._- } 18 \text { in._-_. } & .50 & 4.00 & 32.00 \\ 15 & .60 & 5.00 & 40.00\end{array}$

radicans colorata.

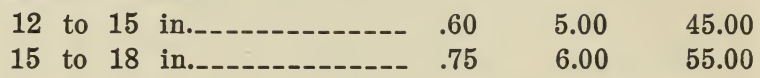

radicans kewensis. Baby Wintercreeper.

8 to 12 in. from pots_-_-_- $.50 \quad 4.00 \quad 32.00$

radicans vegetus. Bigleaf Wintercreeper.

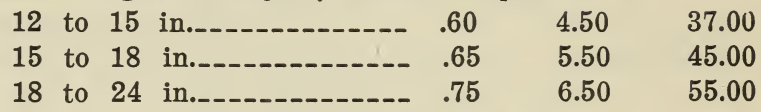

sieboldi.

18 to 24 in.-_. 6.50

2 to 3 ft.--_-_-_-_- $1.00 \quad 7.50$

Ilex crenata. Japanese Holly.

15 in..-_-_-_-_-_ \& B. 3.25

18 in.-_-_-_-_ \& B. 4.50

24 in.-_-_-_-_-_B. \& B. 6.00

glabra. Inkberry.

18 to 24 in._-____ \& B. $3.50 \quad 32.50$

opaca. American Holly.

3 ft._-______-_B. \& B. 10.00

4 ft._-_-_-_-_-_B. \& B. 12.50

5 ft._-_-__-_B. \& B. 15.00

Kalmia latifolia. Mountain Laurel.

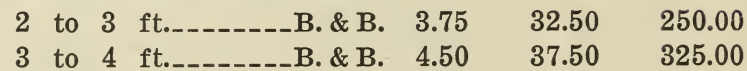

Leucothoe catesbaei. Drooping Leucothoe.

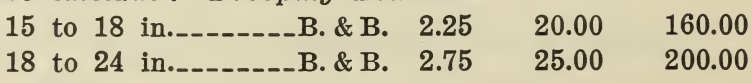

Mahonia aquifolium. Oregon Hollygrape.

\begin{tabular}{|c|c|c|c|c|}
\hline 18 & to 24 & in. & 10.00 & 75.00 \\
\hline & to 30 & in.._- 1.60 & 12.50 & 90.00 \\
\hline $21 / 2$ & to & ft. specimens_- 2.50 & & \\
\hline & $31 / 2$ & ft. specimens_- 3.25 & & \\
\hline
\end{tabular}


Rhododendron carolinianum.

Carolina Rhododendron. each per 10 per 100

2 to 3 ft._-_____B. \& B. $4.50 \quad 37.50 \quad 325.00$

Catawbiense. Catawba Rhododendron.

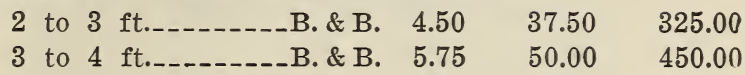

maximum. Rosebay Rhododendron.

2 to 3 ft.-_-_-_B. \& B. $4.00 \quad 35.00 \quad 275.00$

3 to 4 ft._-_-_-_B. \& B. $5.00 \quad 40.00 \quad 350.00$

4 to 5 ft._-_-_-_-_B. \& B. 6.50

\section{Deciduous Trees}

We recommend that all varieties marked with an asterisk be lifted with ball of earth and sewed in burlap. Experience has shown that the loss in these plants, which is otherwise high, is reduced to a minimum if handled in this way. This will involve an extra charge per plant, as follows:

$2-3^{\prime}-30 c ; 3-4^{\prime}-45 c ; 4-5^{\prime}-60 c ; 5-6^{\prime}-75 c ; 6-8^{\prime}-95 c ; 8-10^{\prime}$ $-\$ 1.25$. Larger sizes in proportion. In all instances where the varieties are marked "B. \& B." these charges are included in the printed price.

Acer campestre. Hedge Maple.

\begin{tabular}{|c|c|c|}
\hline 4 to 5 & ft._-_-_- 2.00 & 16.00 \\
\hline 5 to & ft._-_- 2.25 & 20.00 \\
\hline to & ft._- & 22.50 \\
\hline to 10 & ft._-n-n-n-n & 27.50 \\
\hline 10 to 12 & ft. & 47.50 \\
\hline
\end{tabular}

colchicum rubrum. Coliseum Maple.

4 to $5 \mathrm{ft.}$.

10.00

75.00

5 to 6 ft._.-.-.-_-_-_- 1.60

12.50

6 to $8 \mathrm{ft}$._._._._._- 2.25

20.00

90.00

8 to $10 \mathrm{ft.}$.-_-_-_-_-_-_-_- 3.25

25.00

10 to $12 \mathrm{ft.}$ f.--_-_-_-_-_-_-- 3.75

32.50

dasycarpum. Silver Maple.

\begin{tabular}{|c|c|c|c|c|}
\hline 8 & to 10 & ft._._- 2.00 & 16.00 & 125.00 \\
\hline $11 / 4$ & to $11 / 2$ & in._-_-_-_- 2.25 & 20.00 & 160.00 \\
\hline $11 / 2$ & $13 / 4$ & in.-_-_-n 2.50 & 22.50 & 200.00 \\
\hline $13 / 4$ & to & in.-------- 3.25 & 27.50 & 250.00 \\
\hline 2 & $21 / 2$ & in...- 4.00 & 35.00 & 325.00 \\
\hline $21 / 2$ & to & in. & 50.00 & 450.00 \\
\hline 3 & $31 / 2$ & in._- & 65.00 & \\
\hline $31 / 2$ & 4 & in._- 10.00 & 75.00 & \\
\hline
\end{tabular}


Acer

dasycarpum pyramidale. Pyramidal Silver Maple.

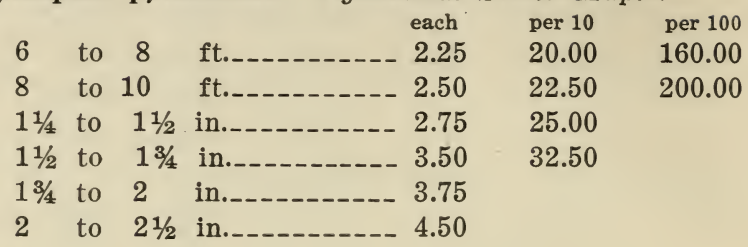

dasycarpum wieri. Wier Maple.

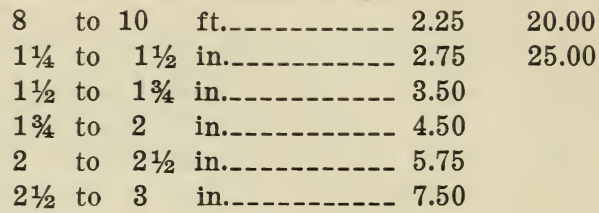

ginnala. Amur Maple.

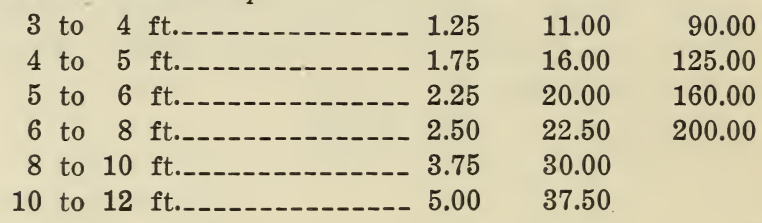

japonicum. Fullmoon Maple.

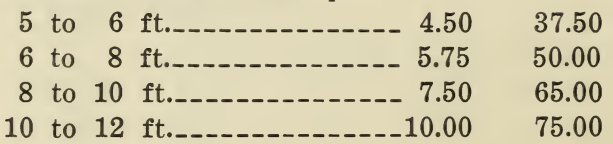

negundo. Box Elder.

\begin{tabular}{|c|c|c|}
\hline 6 & & ft._. \\
\hline & to 10 & ft._-_-_-_-- 2.00 \\
\hline $1 \frac{1}{4}$ & to $11 / 2$ & in._____- 2.25 \\
\hline
\end{tabular}

nigrum. Black Maple.

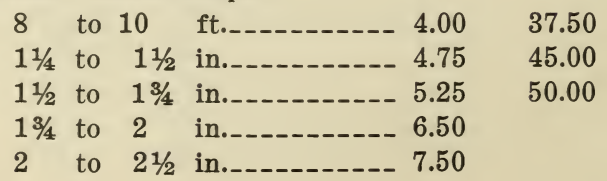


Acer

palmatum. Japanese Maple. each per 10

per 100

3 to $4 \mathrm{ft}$. with ball__-_-_ 6.50 45.00

4 to $5 \mathrm{ft}$. with ball_._-_- 7.50

55.00

5 to $6 \mathrm{ft}$. with ball_..._- 10.00

75.00

6 to $8 \mathrm{ft}$. with ball__-_- 12.50

90.00

8 to $10 \mathrm{ft}$

15.00

125.00

\section{palmatum atropurpureum.}

Bloodleaf Japanese Maple.

3 to $4 \mathrm{ft}$. with ball__-_-_-_ 12.50

4 to $5 \mathrm{ft}$. with ball $\mathrm{XX}$-_-- 17.50

5 to $6 \mathrm{ft}$. with ball $\mathrm{XX}$-_-- 20.00

6 to $8 \mathrm{ft}$. with ball $\mathrm{XX}$-_-_ 25.00

\section{palmatum dissectum.}

Threadleaf Japanese Maple.

2 to $3 \mathrm{ft}$. with ball___._-_._10.00

3 to $4 \mathrm{ft}$. with ball_-_-_-_-- 12.50

palmatum dissectum atropurpureum.

Purple Threadleaf Japanese Maple.

2 to $3 \mathrm{ft}$. with ball_-_-_-_- 10.00

3 to $4 \mathrm{ft}$. with ball_-_-_-_-- 12.50

platanoides. Norway Maple.

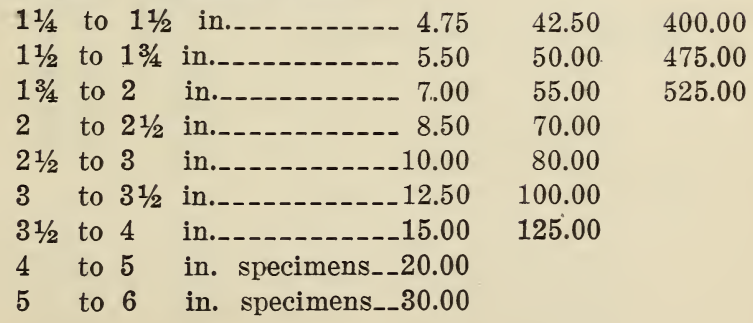

platanoides schwedleri. Schwedler Maple.

\begin{tabular}{|c|c|c|c|}
\hline 8 & to & 10 & 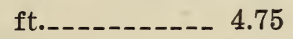 \\
\hline $11 / 4$ & to & $11 / 2$ & in.-_-_--- 5.25 \\
\hline $11 / 2$ & to & $13 / 4$ & in.-_- 6.50 \\
\hline 2 & to & $2 \frac{1}{\prime} / 2$ & in..-10.00 \\
\hline $2 \frac{1}{2}$ & to & 3 & in. \\
\hline 3 & to & $31 / 2$ & --20.00 \\
\hline $31 / 2$ & & 4 & in..-_- 25.00 \\
\hline
\end{tabular}


Acer

pseudoplatanus. Sycamore Maple.

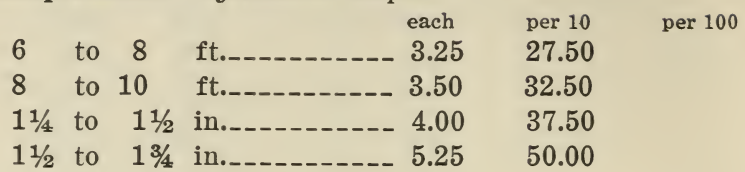

rubrum. Red Maple.

\begin{tabular}{|c|c|c|c|c|}
\hline 6 & to & ft._-_-_-_-_- 2.75 & 25.00 & 225.00 \\
\hline 8 & to 10 & ft.__- & 27.50 & 250.00 \\
\hline $11 / 4$ & to $11 / 2$ & in. & 35.00 & 325.00 \\
\hline $11 / 2$ & $13 / 4$ & in & 45.00 & 375.00 \\
\hline $13 / 4$ & to & 6.50 & 50.00 & \\
\hline 2 & $21 / 2$ & in. & 65.00 & \\
\hline $21 / 2$ & to & in._- 10.00 & & \\
\hline & $31 / 2$ & in... 12.50 & & \\
\hline
\end{tabular}

saccharum. Sugar Maple.

\begin{tabular}{|c|c|c|c|c|}
\hline 8 & to 10 & ft._-_. & 27.50 & 250.00 \\
\hline $11 / 4$ & to $11 / 2$ & in._. & 35.00 & 325.00 \\
\hline $11 / 2$ & $13 / 4$ & in.. & 37.50 & 350.00 \\
\hline $13 / 4$ & to & in..... 5.00 & 45.00 & 400.00 \\
\hline 2 & $21 / 2$ & ---5.50 & 50.00 & \\
\hline $21 / 2$ & to & in.-. 6.50 & 55.00 & \\
\hline 3 & $31 / 2$ & in.. 10.00 & & \\
\hline $31 / 2$ & to 4 & in.--_- & & \\
\hline
\end{tabular}

spicatum. Mountain Maple.

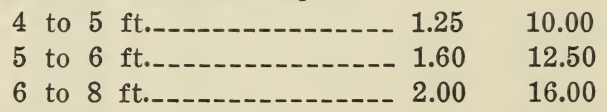

tataricum. Tatarian Maple.
4 to 5 ft._._._._-_._- 2.00
16.00
5 to $6 \mathrm{ft.}$.
6 to 8
3.25
25.00
8 to $10 \mathrm{ft}$.
37.50

Aesculus glabra. Ohio Buckeye.

$$
\begin{aligned}
& 11 / 2 \text { to } 13 / 4 \text { in.--_-_------ } 4.50 \quad 37.50 \\
& 2 \text { to } 2 \frac{1}{2} \text { in........... } 5.50 \\
& 21 / 2 \text { to } 3 \text { in.-_-_-_-_-- } 7.50
\end{aligned}
$$

hippocastanum. Horsechestnut.

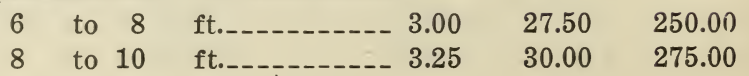


Aesculus

hippocastanum. Horsechestnut. each

per 10

per 100

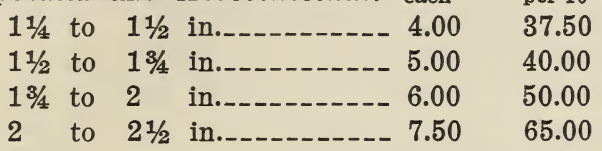

hippocastanum flore pleno.

Double White Horsechestnut.

5 to $6 \mathrm{ft.}$

6 to $8 \mathrm{ft.}$

8 to $10 \mathrm{ft.}$

hippocastanum rubicunda.

Red Horsechestnut.

\begin{tabular}{|c|c|c|c|c|}
\hline 5 & to & ft._. & 32.50 & \\
\hline 6 & to & ft._._. 4.00 & 37.50 & 350.00 \\
\hline 8 & to 10 & ft._- & 45.00 & 400.00 \\
\hline $11 / 4$ & $11 / 2$ & in....... 7.50 & 60.00 & \\
\hline $11 / 2$ & $13 / 4$ & in..... 8.50 & 75.00 & \\
\hline $13 / 4$ & to & in._. 10.00 & 85.00 & \\
\hline 2 & $2^{1 / 2}$ & in. 12.50 & 100.00 & \\
\hline
\end{tabular}

octandra. Yellow Buckeye.

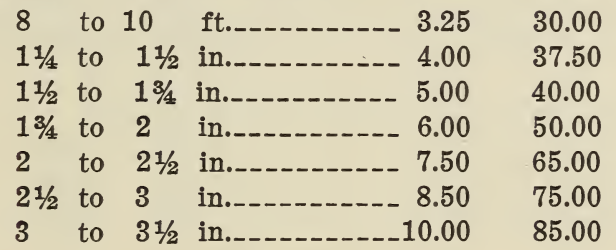

turbinata. Japanese Horsechestnut.

\begin{tabular}{|c|c|c|}
\hline 6 & to & ft._._- 3.75 \\
\hline 8 & to 10 & ft.__- \\
\hline $11 / 4$ & to $11 / 2$ & in....... 5.50 \\
\hline $11 / 2$ & $13 / 4$ & in.._. 6.50 \\
\hline $13 / 4$ & to & in...- 7.50 \\
\hline 2 & $21 / 2$ & in._. 10.00 \\
\hline
\end{tabular}

Ailanthus glandulosa. Tree of Heaven.

5 to $6 \mathrm{ft.}$

$12.50 \quad 90.00$

6 to 8 ft._._._._._.-.-- 2.00

8 to $10 \mathrm{ft}$. 
Alnus cordata. Italian Alder.

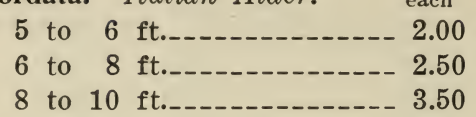

glutinosa. European Alder.

\begin{tabular}{|c|c|c|c|}
\hline 5 & to & ft. & 10.00 \\
\hline 6 & to & ft._._. & 12.50 \\
\hline 8 & to 10 & ft._-_-_- 2.00 & 16.00 \\
\hline $11 / 4$ & to $1 \frac{1}{2}$ & in.._- & 20.00 \\
\hline $11 / 2$ & $13 / 4$ & in.._- & 25.00 \\
\hline $13 / 4$ & to 2 & --3.75 & 32.50 \\
\hline 2 & to $21 / 2$ & in..- 4.50 & 37.50 \\
\hline
\end{tabular}

incana. Speckled Alder.

6 to 8 ft._._._._._- $1.60 \quad 12.50$

8 to 10 ft._._._-_-_- $2.00 \quad 16.00$

$1 \frac{1}{4}$ to $1 \frac{1}{2}$ in.-.-_-_-_-_ $2.25 \quad 20.00$

$11 / 2$ to $13 / 4$ in.._-_-_-_-_ $3.25 \quad 25.00$

$13 / 4$ to 2 in._._._._._. $3.75 \quad 32.50$

2 to $2 \frac{1}{2}$ in..._._._._. $4.50 \quad 37.50$

Amygdalus davidiana. Chinese Wild Peach
4 to $5 \mathrm{ft}$.
5 to $6 \mathrm{ft}$.
10.00

persica alboplena. Double White Peach.

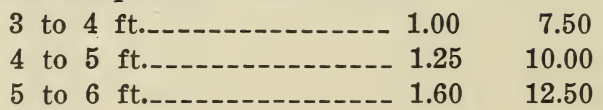

persica Clara Meyer. Double Pink Peach.
3 to $4 \mathrm{ft}$.
$1.60 \quad 12.50$
4 to $5 \mathrm{ft}$.
$2.00 \quad 16.00$

persica rosea plena. Dbl. Pink Peach
3 to $4 \mathrm{ft.}$
4 to 5 ft._-_._-_-_-_- 1.25
5 to $6 \mathrm{ft}$.
12.50

persica rubroplena. Double Red Peach.
4 to $5 \mathrm{ft}$
$1.25 \quad 10.00$
5 to $6 \mathrm{ft}$.
$1.60 \quad 12.50$ 
Aralia. (See Deciduous Shrubs).

*Betula alba. European White Birch.

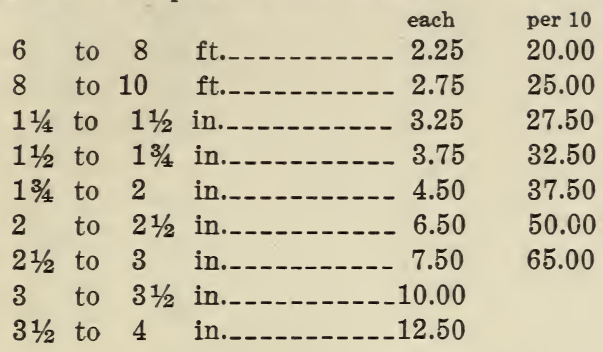

*alba laciniata. Cutleaf Weeping Birch.

\begin{tabular}{|c|c|c|}
\hline 6 & to & ft._. \\
\hline 8 & to 10 & ft.-_-n- \\
\hline $21 / 2$ & to 3 & in. \\
\hline 3 & to & in. \\
\hline
\end{tabular}

*lenta. Sweet Birch.

\begin{tabular}{|c|c|c|}
\hline 5 & to & ft._-_- \\
\hline 6 & to & 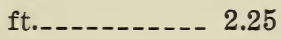 \\
\hline & 10 & $\ldots \ldots-2.75$ \\
\hline $1 / 4$ & $11 / 2$ & in.._. 3.50 \\
\hline
\end{tabular}

*lutea. Yellow Birch.

\begin{tabular}{|c|c|c|c|}
\hline 5 & to & ft._._. & 16.00 \\
\hline 6 & to & ft._-_-_-_-_- 2.25 & 20.00 \\
\hline 8 & to 10 & ft._--_------- 2.75 & 25.00 \\
\hline $1 \frac{1}{4}$ & $11 / 2$ & in..- 3.50 & 32.50 \\
\hline $11 / 2$ & $13 / 4$ & in...... 4.50 & 37.50 \\
\hline $13 / 4$ & to & in.._. & 45.00 \\
\hline
\end{tabular}

*nigra. River Birch.

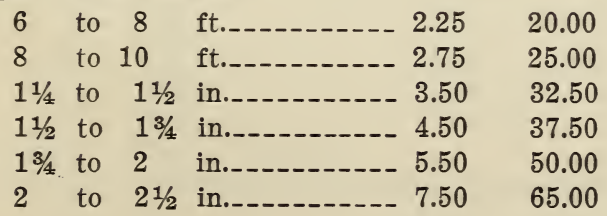

*papyrifera. Canoe Birch.

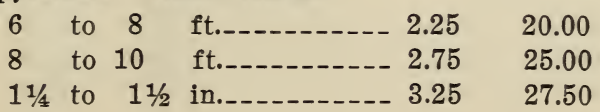


*Betula.

* papyrifera.

$1 \frac{1}{2}$ to $13 / 4$ in.

each

per 10

per 100

$13 / 4$ to 2 in

3.75

32.50

2 to $2 \frac{1}{2}$ in

4.50

37.50

$2 \frac{1}{2}$ to 3

6.50

50.00

65.00

*populifolia. Gray Birch.

\begin{tabular}{|c|c|c|}
\hline & 10 & ft._-_-_---- 2.75 \\
\hline $11 / 4$ & $11 / 2$ & in..-_- 3.25 \\
\hline $11 / 2$ & $13 / 4$ & in._-_. 3.75 \\
\hline $13 / 4$ & 2 & in....... 4.50 \\
\hline
\end{tabular}

Broussonetia papyrifera. Paper Mulberry.

3 to $4 \mathrm{ft.}$.

Carpinus betulus. European Hornbeam.

4 to $5 \mathrm{ft.}$

5 to 6 ft._-_-_-_-_-_-_-_ $2.75 \quad 25.00$

6 to 8 ft._._._-___-_ $3.75 \quad 32.50$

8 to $10 \mathrm{ft}$.._._._._._._. $5.00 \quad 45.00$

10 to $12 \mathrm{ft.}$.

caroliniana. American Hornbeam.

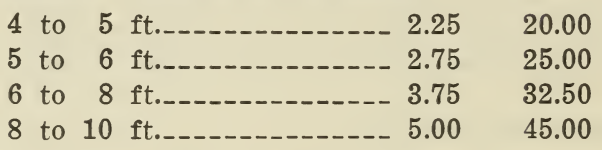

Castanea dentata. American Chestnut.

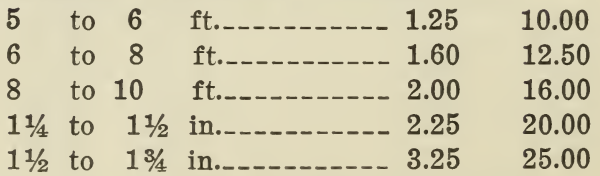

sativa. Spanish Chestnut.

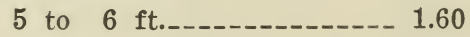

6 to $8 \mathrm{ft.}$.

8 to $10 \mathrm{ft.}$.

10 to $12 \mathrm{ft} . \ldots$

Catalpa bignonioides nana syn. bungei.

Umbrella Catalpa.

$2 \mathrm{yr}$. heads,
5 to
6 to
8 to $10 \mathrm{ft}$. 
Catalpa

kaempferi. Japanese Catalpa. each

per 10

12.50

6 to $8 \mathrm{ft.}$.

8 to $10 \mathrm{ft.}$

10 to 12 ft._-_-_-_-_-_-_- 2.25

speciosa. Western Catalpa.

\begin{tabular}{|c|c|c|c|c|c|}
\hline & to & ft.--------- & 1.25 & 10.00 & 75.00 \\
\hline 8 & to 10 & ft.--_-------- & 1.60 & 12.50 & 90.00 \\
\hline $11 /$ & to $13 / 4$ & in.... & 2.25 & 20.00 & 160.00 \\
\hline 3 & 2 & in.--_- & 2.50 & 22.50 & 200.00 \\
\hline & $21 / 2$ & in. & 3.50 & 27.50 & 250.00 \\
\hline & 3 & in.-- & 4.00 & 35.00 & 325.0 \\
\hline
\end{tabular}

Cedrela sinensis. Chinese Cedrela.

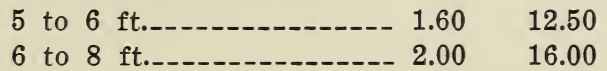

Celtis occidentalis. Hackberry.

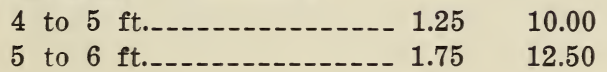

sinensis. Chinese Hackberry.

5 to 6 ft._._-_-_-_-_-_ $1.60 \quad 12.50$

6 to 8 ft..-_-_-_-_-_-- $2.00 \quad 16.00$

*Cercidiphyllum japonicum. Katsura Tree.

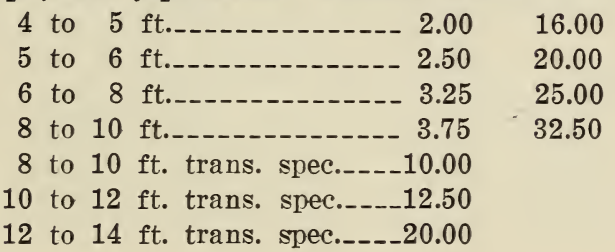

Cercis canadensis. American Redbud.

\begin{tabular}{|c|c|}
\hline 3 to $4 \mathrm{ft}$. & 10.00 \\
\hline 4 to 5 ft.-- 2.00 & 16.00 \\
\hline to $6 \mathrm{ft}$. & 32.50 \\
\hline 6 to $8 \mathrm{ft}$. & \\
\hline
\end{tabular}

chinensis. Chinese Redbud.

2 to $3 \mathrm{ft.}$

Cladrastis lutea. Yellow Wood.

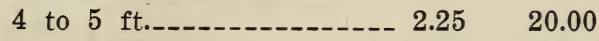

5 to $6 \mathrm{ft}$.._._. 22.50 
*Crataegus.

*mollis. Downy Hawthorn. each per 10

per 100

3 to $4 \mathrm{ft}$.

12.50

4 to $5 \mathrm{ft}$.

2.00

16.00

125.00

5 to $6 \mathrm{ft}$.

2.50

20.00

160.00

6 to $8 \mathrm{ft}$.

$3.75 \quad 25.00$

*nitida. Glossy Hawthorn.

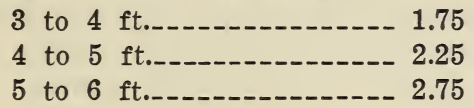

*oxyacantha. English Hawthorn.

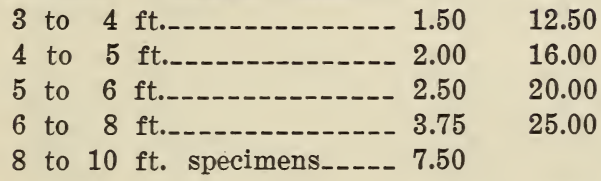

*oxyacantha flora plena. Dbl. White Thorn. 3 to $4 \mathrm{ft.}$

4 to $5 \mathrm{ft}$.

5 to $6 \mathrm{ft}$._-_._-_._- $3.75 \quad 32.50$

6 to $8 \mathrm{ft.}$

8 to $10 \mathrm{ft.}$

8 to $10 \mathrm{ft}$. specimens_-_-_ 10.00

*oxyacantha pauli. Paul's Scarlet Thorn.

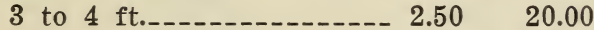

4 to 5 ft._._._._._._._- $3.25 \quad 25.00$

5 to 6 ft._._._._._._._._ $4.50 \quad 37.50$

*oxyacantha punicea. Sgl. Red Thorn.

4 to $5 \mathrm{ft.}$._._._._. $3.25 \quad 25.00$

5 to $6 \mathrm{ft.}$

* persistens.

3 to $4 \mathrm{ft.}$

4 to 5 ft._._.

*punctata. Dotted Hawthorn.

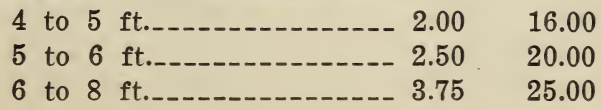


Diospyros virginiana. Common Persimmon.

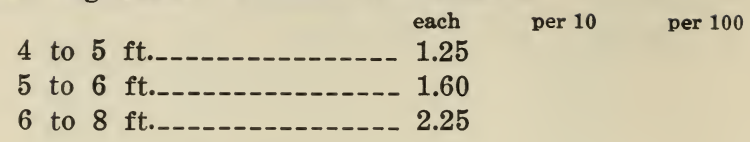

Dirca palustris. Leatherwood.

18 to 24 in._-_-_-_-_-_-_ $1.25 \quad 10.00$

*Fagus americana. American Beech.

\begin{tabular}{|c|c|}
\hline 2 to $3 \mathrm{ft}$. & 16.00 \\
\hline to $4 \mathrm{ft}$. & 20.00 \\
\hline to $5 \mathrm{ft} .-1$ & 25.00 \\
\hline 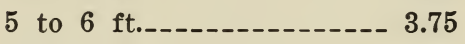 & 32.50 \\
\hline 5.00 & 45.00 \\
\hline
\end{tabular}

*sylvatica. European Beech.

\begin{tabular}{|c|c|c|}
\hline 3 to 4 & 4 ft._------------- 2.75 & 22.50 \\
\hline to & ft._-_- & 27.50 \\
\hline to & ft._-_- 4.50 & 35.00 \\
\hline to & ft._-n-s- 6.50 & 50.00 \\
\hline 10 & ft.-_- 10.00 & \\
\hline
\end{tabular}

*sylvatica heterophylla. Fernleaf Beech.

5 to $5 \mathrm{ft.}$ to $6 \mathrm{ft.}$

*sylvatica pendula. Weeping Beech.

4 to $5 \mathrm{ft.}$.

5 to $6 \mathrm{ft}$.

6 to $8 \mathrm{ft.}$.

*sylvatica purpurea. Purple Beech.
3 to $4 \mathrm{ft}$
$3.75 \quad 32.50$
4 to 5 ft._-_-_-_-_-_-_-_ $4.50 \quad 37.50$
5 to $6 \mathrm{ft.}$
6 to 8 ft.-_-_-_-_-_- $7.50 \quad 65.00$
8 to $10 \mathrm{ft.}$.

*sylvatica purpurea riversi. River's Beech.

\begin{tabular}{|c|c|}
\hline to 4 & ft._-n-n- 5.00 \\
\hline to & ft.-_-n- 6.50 \\
\hline to & ft._-n- 7.50 \\
\hline to & ft.-.-n- 10.00 \\
\hline to 10 & ft.----n-- 12.50 \\
\hline
\end{tabular}


* Fagus

*sylvatica tricolor. Tricolor Beech.

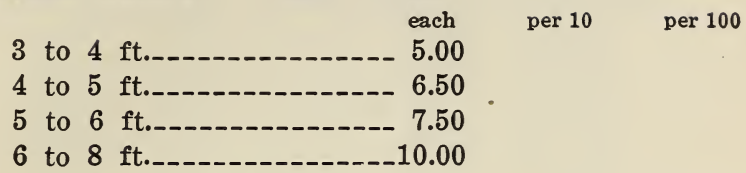

Fraxinus americana. White Ash.

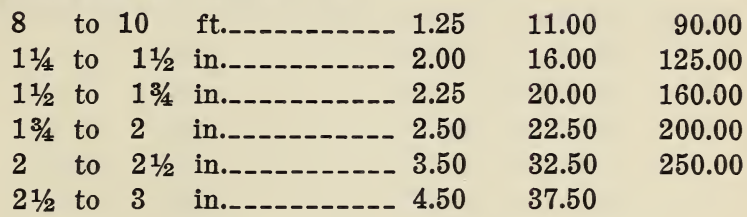

excelsior. European Ash.

\begin{tabular}{|c|c|c|c|c|c|}
\hline 8 & to & 10 & ft._---n---- 1.25 & 11.00 & 90.00 \\
\hline $1 \frac{1}{4}$ & to & $11 / 2$ & in.-_-n- 2.00 & 16.00 & 125.00 \\
\hline $11 / 2$ & to & $13 / 4$ & in.-------- 2.25 & 20.00 & 160.00 \\
\hline $13 / 4$ & to & 2 & in._-_. 2.50 & 22.50 & 200.00 \\
\hline & to & $21 / 2$ & in. & 32.50 & \\
\hline $21 / 2$ & to & 3 & in.-_- 4.50 & 37.50 & \\
\hline & to & $31 / 2$ & 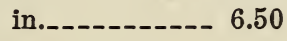 & & \\
\hline
\end{tabular}

lanceolata. Green Ash.

\begin{tabular}{|c|c|c|c|c|}
\hline 8 & to 10 & ft._-_-n 1.25 & 11.00 & 90.00 \\
\hline $11 / 4$ & to $11 / 2$ & in.--_- 2.00 & 16.00 & 125.00 \\
\hline $11 / 2$ & $13 / 4$ & in..-- & 20.00 & 160.00 \\
\hline $13 / 4$ & to & -2.50 & 22.50 & 200.00 \\
\hline 2 & $21 / 2$ & in..-_- 3.50 & 32.50 & 250.00 \\
\hline $21 / 2$ & 3 & in..- & 37.50 & \\
\hline
\end{tabular}

nigra. Black Ash.

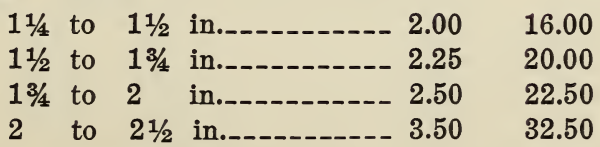

pennsylvanica. Red $A s h$.

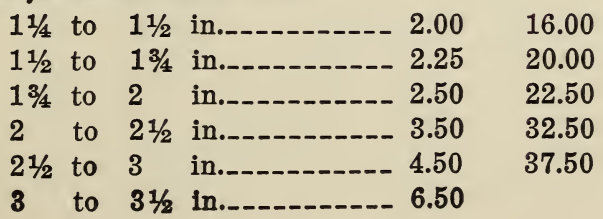


Fraxinus.

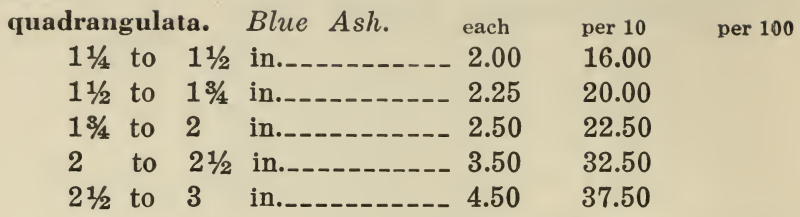

Ginkgo biloba. Maidenhair-tree.

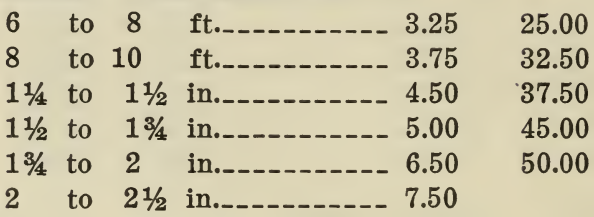

Gleditschia triacanthos. Honey Locust.

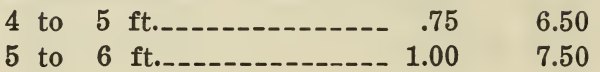

triacanthos inermis. Thornless Honeylocust.

3 to $4 \mathrm{ft.}$

4 to $5 \mathrm{ft.}$.

Gymnocladus dioica. Kentucky Coffeetree.

4 to $5 \mathrm{ft}$.

5 to $6 \mathrm{ft.} .--$

Halesia diptera. Two-wing Silverbell.

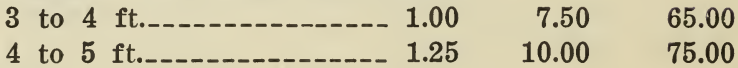

tetraptera. Great Silverbell.

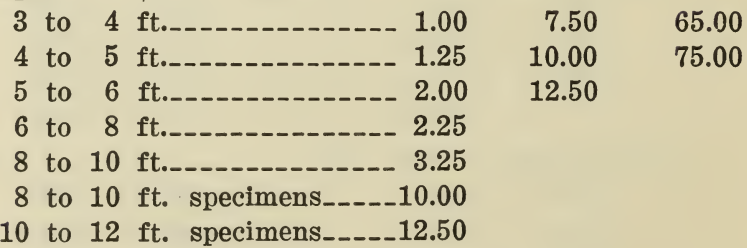

Hicoria ovata. Shagbark Hickory.

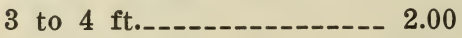

4 to $5 \mathrm{ft}$. 
Juglans cinerea. Butternut. each

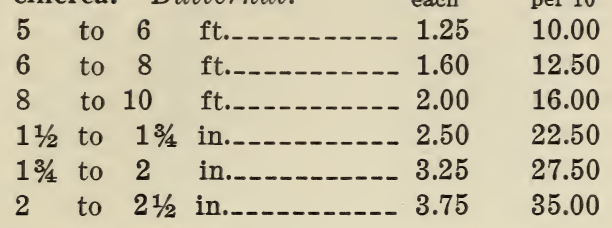

nigra. Black Walnut.

5 to 6 ft._._-_._-_-_ $1.25 \cdot 10.00$

6 to 8 ft._._-_._-_ $1.60 \quad 12.50$

8 to 10 ft._.-.-.-.-.- $2.00 \quad 16.00$

$1 \frac{1}{2}$ to $1 \frac{3 / 4}{4}$ in..........-.- $2.50 \quad 22.50$

$13 / 4$ to 2 in..........- $3.25 \quad 27.50$

2 to $21 / 2$ in.._-_._-_-_ 3.75

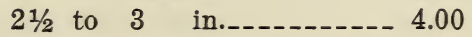

regia. English or Persian Walnut.

2 to 3 ft._._._._._._._._. 1.25

3 to $4 \mathrm{ft.}$.

sieboldiana. Japanese Walnut.

5 to 6 ft._._._-_._- $1.60 \quad 12.50$

6 to 8 ft._.-...-.-.- $2.00 \quad 16.00$

8 to 10 ft._._-_._-_. $2.25 \quad 20.00$

$1 \frac{1}{2}$ to $13 / 4$ in..-..--.--- $2.75 \quad 25.00$

$13 / 4$ to 2 in.-_._-_-_- $3.50 \quad 32.50$

2 to $2 \frac{1}{2}$ in._._._._._. 5.00

Koelreuteria paniculata. Goldenrain Tree.

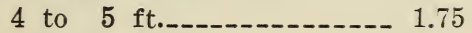
5 to $6 \mathrm{ft.}$
17.50
6 to $8 \mathrm{ft.}$

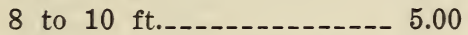

Laburnum alpinum. Scotch Laburnum.
4 to 5 ft._._.......-. 2.00
16.00
5 to $6 \mathrm{ft}$................ 2.50
22.50
6 to $8 \mathrm{ft}$. heary-_.-_-_-- 6.50
8 to $10 \mathrm{ft}$. heary-_._-_._- 10.00

vulgare. Goldenchain.

\begin{tabular}{|c|c|}
\hline 3 to & 4 ft.t-1. 1.60 \\
\hline to & 5 ft._._- 2.00 \\
\hline to & ft........ 2.50 \\
\hline to & $8 \mathrm{ft}$. heary-_-_- 6.50 \\
\hline to 1 & $0 \mathrm{ft}$. heary \\
\hline to 18 & $2 \mathrm{ft}$. heavy \\
\hline
\end{tabular}


*Larix europea. European Larch. each per 10

4 to $5 \mathrm{ft.}$

per 100

5 to 6

3.25

25.00

125.00

6 to 8

4.50

37.50

8 to 10

6.50

50.00

10 to $12 \mathrm{ft}$

*leptolepis. Japanese Larch.

\begin{tabular}{|c|c|}
\hline 4 to 5 & ft._-_- \\
\hline to & ft._-_-n- 3.25 \\
\hline to & ft._-_- 4.50 \\
\hline to 10 & ft._-1-10- 6.50 \\
\hline 12 & --10.00 \\
\hline
\end{tabular}

*Liquidambar styraciflua. Sweetgum.

\begin{tabular}{|c|c|c|c|}
\hline 6 & to & 8 & ft.-_-------- 2.75 \\
\hline 8 & to & 10 & ft.--n---n- 3.50 \\
\hline $11 / 4$ & to & $11 / 2$ & in..-_- 3.75 \\
\hline $11 / 2$ & to & $13 / 4$ & in._-_-_- 4.00 \\
\hline $13 / 4$ & to & 2 & in.-_-n 4.50 \\
\hline 2 & to & $21 / 2$ & in.-n- 6.50 \\
\hline $21 / 2$ & to & 3 & in..-_- 10.00 \\
\hline & to & $31 / 2$ & in..... 12.50 \\
\hline
\end{tabular}

*Liriodendron tulipifera. Tuliptree.

\begin{tabular}{|c|c|c|c|c|}
\hline 5 & to & ft._-_- 1.50 & 12.50 & \\
\hline 6 & to & ft.---_- 2.00 & 16.00 & 125.00 \\
\hline 8 & to 10 & ft._-_-_--- 2.75 & 20.00 & 160.00 \\
\hline $11 / 4$ & to $11 / 2$ & in. & 25.00 & 200.00 \\
\hline $11 / 2$ & $1 \% / 4$ & in... 3.25 & 27.50 & 225.00 \\
\hline $13 / 4$ & to & in. & 30.00 & 275.00 \\
\hline 2 & $2 \frac{1}{2}$ & in.-- & 37.50 & \\
\hline $21 / 2$ & to & in.._- 5.00 & 45.00 & \\
\hline & $31 / 2$ & in.._- 7.50 & & \\
\hline
\end{tabular}

tulipifera pyramidale. Pyramid Tuliptree.
5 to $6 \mathrm{ft}$ 6.50
6 to $8 \mathrm{ft}$. 8.50

Magnolia acuminata. Cucumber Tree.

\begin{tabular}{|c|c|c|c|}
\hline 6 & to & ft._-_- & 2.00 \\
\hline 3 & to 10 & ft.n-n- & 2.50 \\
\hline $1 / 2$ & to $13 / 4$ & in.-_- & 3.25 \\
\hline $13 / 4$ & to & in.---_----- & 3.75 \\
\hline & $21 / 2$ & in. & 4.50 \\
\hline $1 / 2$ & to 3 & in. & .00 \\
\hline
\end{tabular}


Magnolia.

glauca.

2 to $3 \mathrm{ft}$ with ball 3.25

per 10

per 100

2 to $3 \mathrm{ft}$. With ball-_---- 3.25

25.00

225.00

3 to $4 \mathrm{ft}$. with ball_._-_-- 4.50

37.50

300.00

4 to $5 \mathrm{ft}$. with ball_._._- 6.50

50.00

450.00

5 to $6 \mathrm{ft}$. with ball_._-_-- 7.50

65.00

6 to $8 \mathrm{ft}$. with ball__._._. 10.00

75.00

8 to $10 \mathrm{ft}$. with ball_-_-_- 12.50

90.00

10 to $12 \mathrm{ft}$. with ball

15.00

125.00

*hypoleuca. Silver Magnolia.

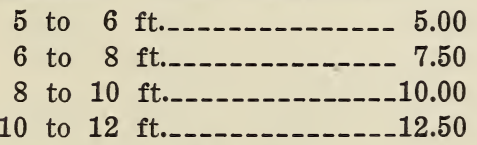

*kobus. Kobus Magnolia.

4 to $5 \mathrm{ft.}$

5 to $6 \mathrm{ft.}$

6 to $7 \mathrm{ft}$.

7 to $8 \mathrm{ft.}$

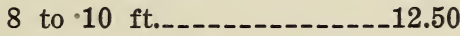

lennei. Lenne Magnolia.

4 to $5 \mathrm{ft}$. with ball_-_-_-_ 15.00

soulangeana. Saucer Magnolia.

4 to $5 \mathrm{ft}$. with ball__-_-_-_15.00

tripetala. Umbrella Magnolia.

5 to $6 \mathrm{ft}$. with ball_-_-_-- 5.00

6 to $8 \mathrm{ft}$. with ball_._.-.- 7.50

8 to $10 \mathrm{ft}$. with ball_-_--- 10.00

10 to $12 \mathrm{ft}$. with ball_____-12.50

Malus arnoldiana. Arnold Crab.

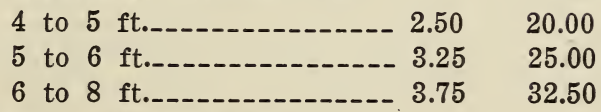

baccata. Siberian Crab.

3 to $4 \mathrm{ft}$..--_.-_- $2.00 \quad 12.50$

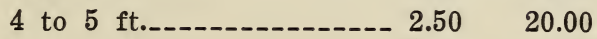

5 to $6 \mathrm{ft.}$

6 to $8 \mathrm{ft.}$

coronaria. Wild Sweet Crab.

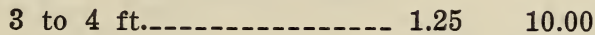

75.00

4 to $5 \mathrm{ft.}$

12.50

90.00

5 to $6 \mathrm{ft}$.

6 to $8 \mathrm{ft}$ 
Malus.

floribunda. Japanese Flowering Crab.

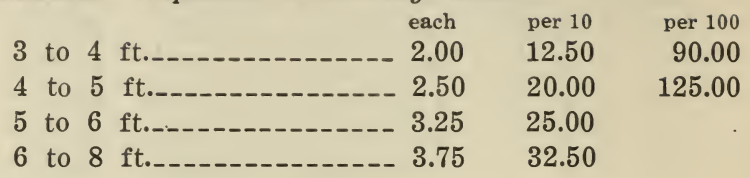

floribunda atrosanguinea. Carmine Crab.

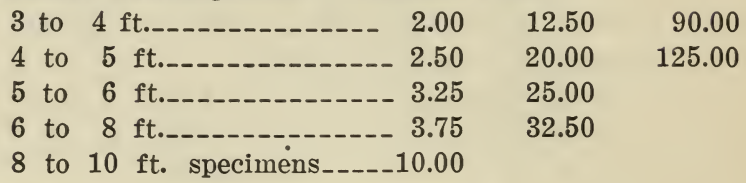

floribunda purpurea. Purple Crab.

3 to $4 \mathrm{ft.}$.-_-_-_-_- $2.00 \quad 12.50$

4 to 5 ft._-_-_-_-_-_-_-_ $2.50 \quad 20.00$

5 to $6 \mathrm{ft.}$..-_-_-_-_-_-_-- $3.25 \quad 25.00$

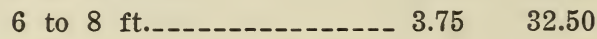

halliana parkmani. Parkman Crab.

3 to 4 ft._-_-_-_-_-_-_-_- $2.50 \quad 20.00$

4 to $5 \mathrm{ft.}$._-_-_-_-_-_-_-- $3.25 \quad 25.00$

5 to $6 \mathrm{ft}$.

ioensis bechteli. Bechtel Crab.

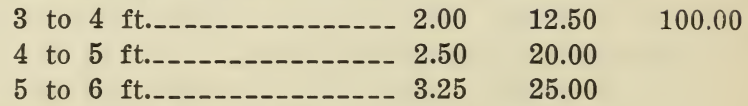

micromalus. Midget Crab.

3 to $4 \mathrm{ft.}$

niedzwetzkyana. Redvein Crab.

3 to 4 ft.--_-_-_-_-_-_---- $2.00 \quad 12.50$

4 to $5 \mathrm{ft.}$.-_-_-_-_-_-_---- $2.50 \quad 20.00$

5 to $6 \mathrm{ft.}$.-_-_-_-_-_-_-- $3.25 \quad 25.00$

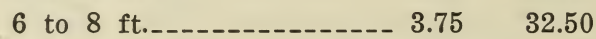

prunifolia rinki. Chinese Apple.

3 to $4 \mathrm{ft.}$.

sargenti. Sargent Crab.

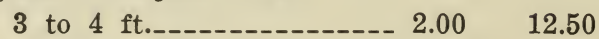

scheideckeri. Scheidecker Crab.

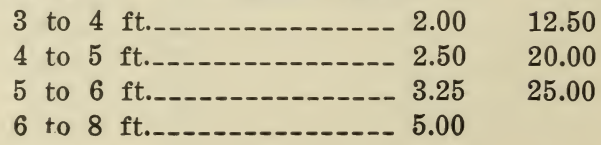


Malus.

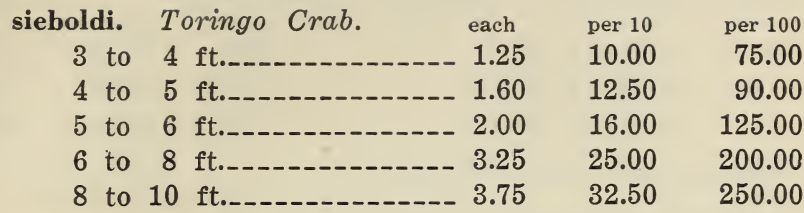

sieboldi callicarpa.

Small-fruited Toringo Crab.

\begin{tabular}{|c|}
\hline 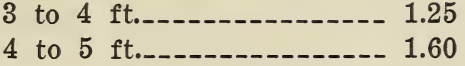 \\
\hline to $6 \mathrm{ft}$. \\
\hline
\end{tabular}

spectabilis. Chinese Flowering Crab.

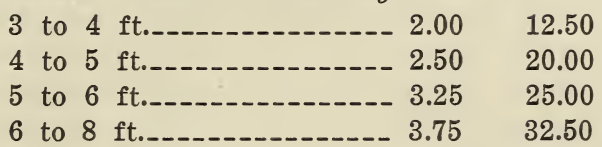

spectabilis alba plena.

Dbl. White Chinese Crab.

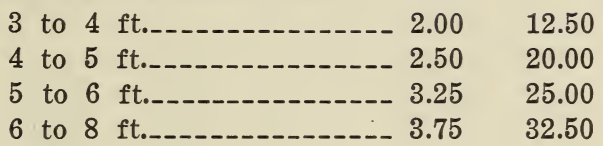

zumi. Zumi Crab.

\begin{tabular}{|c|c|}
\hline 3 to & $\mathrm{ft}$. \\
\hline to & ft.--1-- \\
\hline to & ft.--_-n-- 3.25 \\
\hline to & 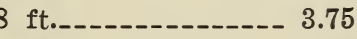 \\
\hline to 10 & ft._- \\
\hline
\end{tabular}

Morus alba pendula. Weeping Mulberry $2 \mathrm{yr}$. heads, 5 to $7 \mathrm{ft}$. stems 3.75

alba tartarica. Russian Mulberry.

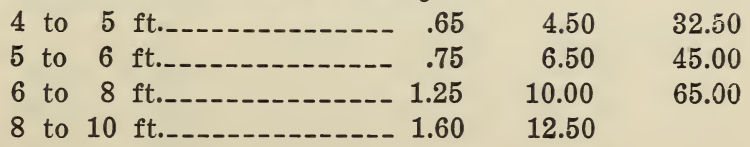

Nyssa sylvatica. Tupelo.

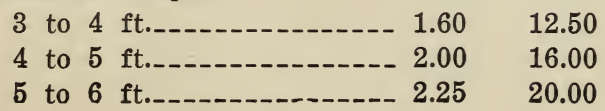


Ostrya virginiana. American Hophornbeam.

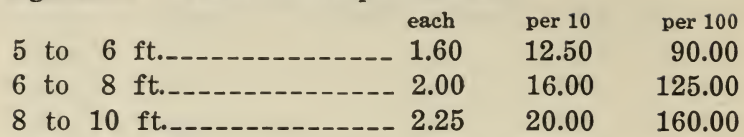

Oxydendrum. (See Shrubs).

Paulownia tomentosa. Royal Paulownia.

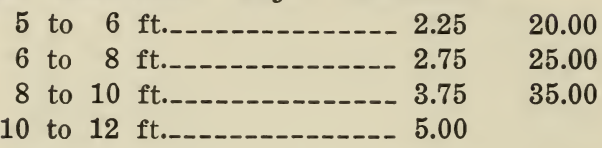

Phellodendron amurense. Amur Corktree.

\begin{tabular}{|c|c|c|c|}
\hline 6 & to 8 & ft.-_-_-_--- 2.00 & 16.00 \\
\hline 8 & to 10 & ft._-_-_-_-_- 2.50 & 22.50 \\
\hline $11 / 4$ & $11 / 2$ & in._-_-_-_-_- 3.25 & 27.50 \\
\hline $11 / 2$ & $13 / 4$ & in.-_-_-_- 3.50 & 32.50 \\
\hline $13 / 4$ & to & in._-__- 3.75 & 35.00 \\
\hline 2 & $21 / 2$ & in._- & 37.50 \\
\hline $21 / 2$ & to & in..- & 45.00 \\
\hline 3 & $31 / 2$ & in.-- 6.50 & 50.00 \\
\hline
\end{tabular}

Platanus orientalis. European Planetree.

\begin{tabular}{|c|c|c|c|c|}
\hline $11 / 4$ to & $11 / 2$ & in._-_-_-_- 3.25 & 27.50 & 250.00 \\
\hline $11 / 2$ & $13 / 4$ & in._-_- 3.50 & 32.50 & 275.00 \\
\hline $13 / 4$ & 2 & in._-_- 5.00 & 45.00 & 375.00 \\
\hline to & $21 / 2$ & in._- 6.50 & 50.00 & 450.00 \\
\hline $2 \mathrm{t}$ & 3 & in._. 7.50 & 60.00 & \\
\hline
\end{tabular}

Populus alba. White Poplar.

\begin{tabular}{|c|c|c|c|c|}
\hline 6 & to & ft._---------- 1.10 & 10.00 & 75.00 \\
\hline 8 & to 10 & ft._-_-_-_-_-- 1.25 & 11.00 & 90.00 \\
\hline 10 & to 12 & ft._-n-- 2.00 & 16.00 & 125.00 \\
\hline $11 / 2$ & to $13 / 4$ & in._-_. & 20.00 & \\
\hline $13 / 4$ & to & in.-_-_- 3.25 & 25.00 & \\
\hline & $21 / 2$ & - 4.00 & 30.00 & \\
\hline
\end{tabular}

bolleana. Bolleana Poplar

\begin{tabular}{|c|c|c|c|}
\hline 6 & to & 8 & ft._. \\
\hline 8 & to & 10 & ft._-_- \\
\hline $11 / 4$ & to & $11 / 2$ & in.-_- 3.25 \\
\hline $11 / 2$ & to & $13 / 4$ & in._- 3.75 \\
\hline $13 / 4$ & to & 2 & in.-_- 5.00 \\
\hline 2 & to & $21 / 2$ & in.-_- 6.50 \\
\hline 21 & & 3 & in. \\
\hline
\end{tabular}


Populus.

certinensis. Certinensis Poplar

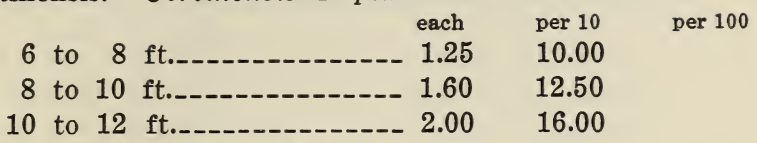

nigra italica. Lombardy Poplar.

6 to 8 ft. low branched 1.00

7.50

65.00

8 to $10 \mathrm{ft}$. low branched 1.25

10.00

75.00

10 to 12 ft. low branched 2.00

16.00

110.00

$1 \frac{1}{2}$ to $13 / 4$ in. low branched 2.25

20.00

$13 / 4$ to 2 in. low branched 3.25

25.00

2 to $2 \frac{1}{2}$ in. low branched 4.50

37.50

$2 \frac{1}{2}$ to 3 in. low branched 6.50

50.00

trichocarpa. Black Cottonwood.

$$
\begin{aligned}
& 6 \text { to } 8 \mathrm{ft} . \ldots-\ldots \\
& 8 \text { to } 10 \mathrm{ft.} . \\
& 10 \text { to } 12 \mathrm{ft.}
\end{aligned}
$$

\begin{tabular}{|c|c|}
\hline to & ft.--n--n- 4.50 \\
\hline to 8 & ft._-n- 6.50 \\
\hline to 10 & ft._-n 10.00 \\
\hline to 4 & in. specimens_-_-_20.00 \\
\hline
\end{tabular}

Prunus avium plena.

Double White Flowering Cherry

lannesiana. Hitoye Cherry.

$$
\begin{aligned}
& 4 \text { to } 5 \mathrm{ft.} \\
& 5 \text { to } 6 \mathrm{ft.} \\
& 6 \text { to } 8 \mathrm{ft.}
\end{aligned}
$$

padus. European Bird Cherry.

\begin{tabular}{|c|c|c|c|}
\hline to & ft._-_- 2.00 & 16.00 & 125.00 \\
\hline to & ft.-_- & 20.00 & 160.00 \\
\hline 6 & -- 3.75 & 32.50 & 225.00 \\
\hline to 10 & ft._-n- 5.00 & 37.50 & \\
\hline
\end{tabular}

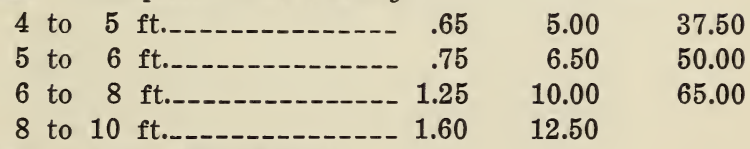

persica. (See Amygdalus).

serotina. Wild Black Cherry.

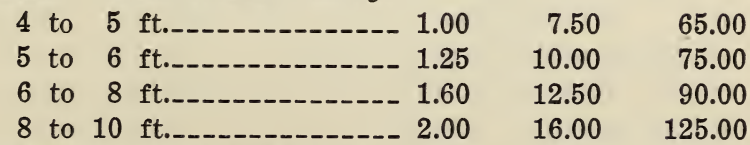

serrulata. Oriental Cherry. 


\section{Prunus.}

serrulata Higantakura. Dbl. White Flg. Cherry.

$$
\begin{aligned}
& \text { each per } 10 \text { per } 100 \\
& 4 \text { to } 5 \text { ft.-_-_-_-_-_-_-_- } 3.25 \\
& 5 \text { to } 6 \mathrm{ft} \text {._._-_._- } \\
& 6 \text { to } 8 \text { ft._-_-_-_-_-_- } 6.50 \\
& 8 \text { to } 10 \mathrm{ft.}
\end{aligned}
$$

serrulata Hisakura. Dbl. Pink Flg. Cherry.

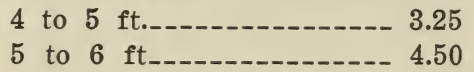

serrulata James H. Veitch.

$$
\begin{aligned}
& 4 \text { to } 5 \mathrm{ft.} \\
& 5 \text { to } 6 \mathrm{ft.} .
\end{aligned}
$$

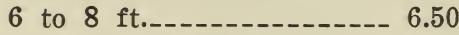

serrulata sachalinensis. Yama Cherry.

$$
\begin{aligned}
& 4 \text { to } 5 \text { ft._._._._._._. } 2.00 \quad 16.50 \\
& 5 \text { to } 6 \text { ft._-_-_-_-_-_-_- } 2.50 \quad 20.00 \\
& 6 \text { to } 8 \text { ft._._._._-_._-_ } 3.75 \quad 32.50 \\
& 8 \text { to } 10 \text { ft._._._-_._-_ } 5.00 \quad 45.00
\end{aligned}
$$

sieboldi. Siebold Cherry.

$$
\begin{array}{r}
6 \text { to } 8 \mathrm{ft.} \\
8 \text { to } 10 \mathrm{ft.}
\end{array}
$$

subhirtella. Higan Cherry.

$$
\begin{aligned}
& 4 \text { to } 5 \text { ft.-_-_-_-_-_-_-_- } 2.75 \quad 25.00 \\
& 5 \text { to } 6 \mathrm{ft.} \\
& 6 \text { to } 8 \mathrm{ft.} .
\end{aligned}
$$

subhirtella autumnale.

$$
\begin{aligned}
& \text { Autumn flowering Higan Cherry. } \\
& 4 \text { to } 5 \text { ft._._._._._._. } 3.25 \quad 25.00 \\
& 5 \text { to } 6 \text { ft._-_-_-_-_-_-_ } 4.50 \quad 37.50 \\
& 6 \text { to } 8 \text { ft._-_-_-_-_-_- } 6.50 \quad 50.00 \\
& 8 \text { to } 10 \mathrm{ft} \text {.._-_._-_._- } 9.00
\end{aligned}
$$

subhirtella pendula. Weeping Higan Cherry.

$2 \mathrm{yr}$. heads, 4 to $6 \mathrm{ft}$. stem 6.50 yedoensis. Yoshino Cherry.

$$
5 \text { to } 6 \mathrm{ft.} .-1-\ldots
$$

Ptelea trifoliata. Hoptree.

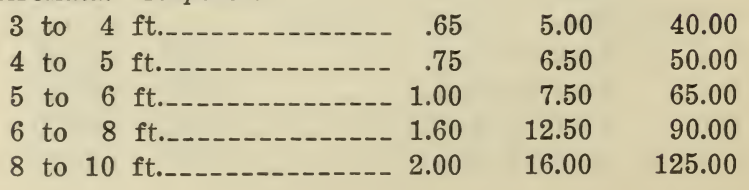


Quercus alba. White Oak. each

6 to 8 ft._._._._._. 3.75

per 10

per 100

$11 \frac{1}{4}$ to $11 / 2$ in............. 4.50

32.50

$1 \frac{1}{2}$ to $13 / 4$ in

37.50

$13 / 4$ to 2

6.50

45.00

2 to $2 \frac{1}{2}$ in.

7.50

50.00

$21 / 2$ to 3

cerris. European Turkey Oak.

6 to 8 ft._..._._._. 3.25

25.00

$11 / 4$ to $11 / 2$ in..........-.-. 3.50

32.50

$11 / 2$ to $13 / 4$ in

4.00

37.50

$13 / 4$ to 2

4.75

45.00

2 to $2 \frac{1}{2}$ in...........- 6.50

55.00

$21 / 2$ to 3

67.50

coccinea. Scarlet Oak.

$11 / 4$ to $1 \frac{1}{2}$ in............. 4.50

$11 / 2$ to $13 / 4$ in............ 5.00

$13 / 4$ to 2 in.-_..-_..- 6.50

2 to $2 \frac{1}{2}$ in.........-. 7.50

$21 / 2$ to 3 in.......- 10.00

3 to $31 / 2$ in..-_-_-_-_-_ 12.50

$31 / 2$ to 4 in........ 17.50

ilicifolia. Scrub Oak.

$1 \frac{1}{4}$ to $1 \frac{1}{2}$ in._._........ $3.50 \quad 32.50$

$1 \frac{1 / 2}{2}$ to $13 / 4$ in..-_._-_-_-_ $3.75 \quad 35.00$

$13 / 4$ to 2 in._._._._._._ $4.50 \quad 37.50$

2 to $2 \frac{1}{2}$ in.......... $6.50 \quad 50.00$

macrocarpa. Mossycup Oak.

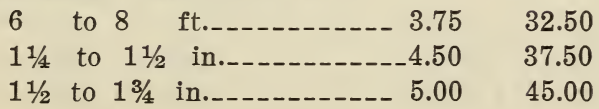

palustris. Pin Oak.

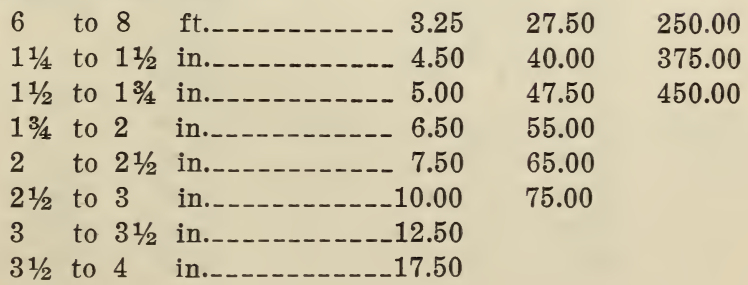


Quercus.

phellos. Willow Oak.

$$
\begin{aligned}
& 5 \text { to } 6 \mathrm{ft} \text {. } \\
& \text { each per } 10 \\
& 6 \text { to } 8 \mathrm{ft}
\end{aligned}
$$

\begin{tabular}{|c|c|c|c|}
\hline & to 8 & ft._-_-_-n-- 3.25 & 25.00 \\
\hline $1 / 4$ & to $11 / 2$ & in..-_-_- 3.75 & 32.50 \\
\hline & to $13 / 4$ & in.-_-_- 4.50 & \\
\hline & & 5.00 & .0 \\
\hline & to $21 / 2$ & -6.50 & .0 \\
\hline & & & \\
\hline
\end{tabular}$$
\text { per } 100
$$

200.00

prinus. Chestnut Oak.

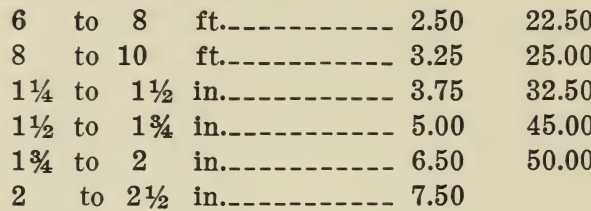

robur. English Oak.

rubra. Red Oak.

6 to 8 ft._._._._-_- $3.75 \quad 32.50$

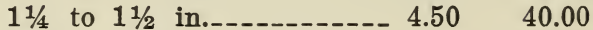

$1 \frac{1 / 2}{2}$ to $1 \frac{8 / 4}{4}$ in.-_-_-_-_-_ $5.00 \quad 47.50$

$13 / 4$ to 2 in._-_._-_-_ $6.50 \quad 55.00$

2 to $2 \frac{1}{2}$ in..-_-_-_-_ $7.50 \quad 65.00$

$2 \frac{1}{2}$ to 3 in._-_._-_ $10.00 \quad 75.00$

3 to $31 / 2$ in.-_-_-_-_-_ 12.50

velutina. Black Oak.

6 to 8 ft._._-_._-_- $3.75 \quad 32.50$

$11 / 4$ to $1 \frac{1}{2}$ in._._._. $4.50 \quad 37.50$

$11 / 2$ to $13 / 4$ in.-_-_-_-_- $5.00 \quad 45.00$

$13 / 4$ to 2 in._._._. $6.50 \quad 50.00$

2 to $2 \frac{1}{2}$ in.....-_-_-_ $7.50 \quad 65.00$

$21 / 2$ to 3 in._._._._. $10.00 \quad 75.00$

3 to $3 \frac{1}{2}$ in......-..-_ 12.50

$31 / 2$ to 4 in.--_-_--_- 16.00

Robinia pseudoacacia. Common Locust.

5 to $6 \mathrm{ft}$.

6 to $8 \mathrm{ft.}$

8 to $10 \mathrm{ft}$ 


\section{Robinia}

hispida. Rose Acacia.

$$
\text { each }
$$

per 10

per 100

2 yr. standard, 3 to 4 ft.-- 2.00

2 yr. standard, 4 to 5 ft.-- 2.50

Salix babylonica. Babylon Weeping Willow.

\begin{tabular}{|c|c|c|c|c|}
\hline 6 & to & 8 & ft......-.-n & 1.6 \\
\hline 8 & to & 10 & ft._-n--n---n- & 2.0 \\
\hline $11 / 4$ & to & $11 / 2$ & in......- & 2.2 \\
\hline $11 / 2$ & to & $13 / 4$ & in........ & 2.5 \\
\hline $3 / 4$ & to & 2 & in. & 3.2 \\
\hline & & $21 / 2$ & in.-- & 3.7 \\
\hline
\end{tabular}

babylonica aurea pendula. Golden Weeping Willow.

\begin{tabular}{|c|c|c|c|}
\hline 6 & to & ft._-n 1.60 & 12.50 \\
\hline 8 & to 10 & ft._. & 16.00 \\
\hline $11 / 4$ & to $11 / 2$ & in._. & 20.00 \\
\hline $11 / 2$ & $13 / 4$ & in._-_- 2.50 & 22.50 \\
\hline $13 / 4$ & to & in._-_. 3.25 & 25.00 \\
\hline
\end{tabular}

babylonica dolorosa. Wisconsin Weeping Willow.
6 to $8 \mathrm{ft}$.
1.60
12.50
8 to $10 \mathrm{ft}$.
2.00
16.00

babylonica salamoni. Salamon Weeping Willow.

\begin{tabular}{|c|c|c|c|c|}
\hline 6 & to & ft._-n- 1.60 & 12.50 & 90.00 \\
\hline 8 & to 10 & ft._-------- 2.00 & 16.00 & 125.00 \\
\hline $11 / 4$ & to $11 / 2$ & in._. & 20.00 & 160.00 \\
\hline $11 / 2$ & $13 / 4$ & in._. & 22.50 & 200.00 \\
\hline $13 / 4$ & to & in. & 27.50 & \\
\hline 2 & $2 \frac{1}{2}$ & in...... 3.75 & 32.50 & \\
\hline $21 / 2$ & to & in..- 5.00 & 37.50 & \\
\hline & to $3 \frac{1 / 2}{2}$ & in...- 6.50 & & \\
\hline
\end{tabular}

caprea. Goat Willow.

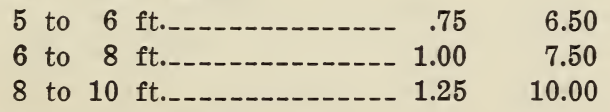

discolor. Pussy Willow.

4 to $5 \mathrm{ft.}$

5 to $6 \mathrm{ft.}$.

pentandra. Laurel Willow.

\begin{tabular}{|c|c|c|c|}
\hline 6 & to & ft._-_-_- & 12.50 \\
\hline 8 & to 10 & ft._-_-_-_------ & 16.00 \\
\hline $11 / 4$ & to $1 \frac{1}{2}$ & in. & 20.00 \\
\hline $11 / 2$ & $13 / 4$ & in... & 22.50 \\
\hline $13 / 4$ & to & in. & 27.50 \\
\hline
\end{tabular}


Salix.

\begin{tabular}{|c|c|c|c|c|}
\hline regalis & - $R o$ & yal Willow. & each & per 10 \\
\hline 4 & to 5 & 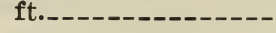 & 1.00 & 6.50 \\
\hline 5 & & ft..-n- & 1.25 & 10.00 \\
\hline 6 & to & ft._- & 1.60 & 12.50 \\
\hline 8 & to 10 & 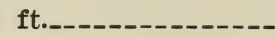 & 2.00 & 16.00 \\
\hline 10 & to 12 & ft.-- & 2.25 & 20.00 \\
\hline
\end{tabular}

rosmarinifolia. (See Shrubs).

sieboldiana. Siebold Willow.

6 to $8 \mathrm{ft.}$
8 to $10 \mathrm{ft.}$.

vitellina. Golden Willow.

\begin{tabular}{|c|c|c|c|c|}
\hline 6 & to & ft._-n- 1.25 & 10.00 & 75.00 \\
\hline 8 & to 10 & ft._-_-n 1.60 & 12.50 & 90.00 \\
\hline $1 / 4$ & to $1 \frac{1 / 2}{2}$ & in..- 2.00 & 16.00 & 125.00 \\
\hline $1 / 2$ & $13 / 4$ & in.-_-_- & 20.00 & 160.00 \\
\hline $3 / 4$ & to & in..- 2.50 & 22.50 & 200.00 \\
\hline & $21 / 2$ & -- 3.25 & 27.50 & \\
\hline & to 3 & in.-- 3.75 & 32.50 & \\
\hline
\end{tabular}

vitellina britzensis. Bronze Golden Willow.

5 to 6 ft._-_-_-_-_ $1.00 \quad 7.50$

65.00

6 to 8 ft.-_-_-_- $1.25 \quad 10.00$

75.00

8 to 10

12.50

$11 / 2$ to $13 / 4$ in

20.00

$13 / 4$ to 2

1.60

90.00

Sassafras variifolium. Sassafras.

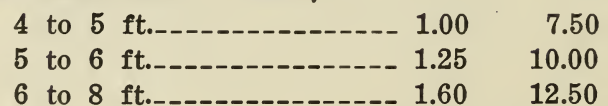

Sorbus americana. American Mountain Ash.

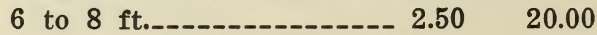

aria latifolia. White Beam-tree.

6 to $8 \mathrm{ft.}$
8 to $10 \mathrm{ft.}$

aucuparia. European Mountain Ash.

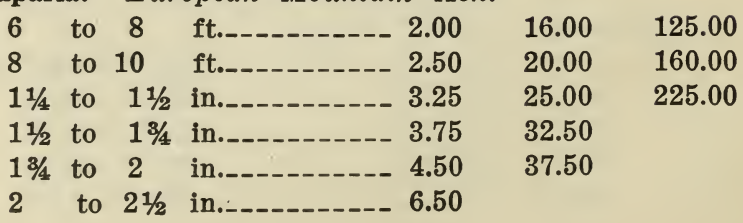


Sorbus.

quercifolia. Oak-leaf Mountain Ash.

\begin{tabular}{|c|c|c|c|}
\hline 6 & to & $\begin{aligned} & \text { each } \\
\text { ft._____-_. } & 2.25\end{aligned}$ & $\begin{array}{l}\text { per } 10 \\
20.00\end{array}$ \\
\hline 8 & to 10 & ft.____n_- 2.75 & 25.00 \\
\hline $11 / 4$ & to $11 / 2$ & in.-_-_ & 27.50 \\
\hline $11 / 2$ & $13 / 4$ & in._-_. 3.75 & 32.50 \\
\hline $13 / 4$ & to & in..... 4.50 & 37.50 \\
\hline & $21 / 2$ & in...... 6.50 & \\
\hline
\end{tabular}

Syringa japonica. (See Deciduous Shrubs).

Taxodium distichum. Common Baldcypress.

$$
\begin{aligned}
& 3 \text { to } 4 \mathrm{ft.} . \\
& 4 \text { to } 5 \text { ft._._-_-_-_-_- } 1.75
\end{aligned}
$$

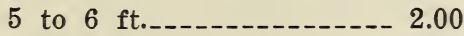

$$
\begin{aligned}
& 6 \text { to } 8 \mathrm{ft.}
\end{aligned}
$$

\begin{tabular}{|c|c|c|c|}
\hline 6 & to & ft.-_-_- & 25.00 \\
\hline 8 & to 10 & ft._-_-_-_- 3.75 & 35.00 \\
\hline $11 / 4$ & to $11 / 2$ & in...- 4.50 & 40.00 \\
\hline $11 / 2$ & $13 / 4$ & in...-. & 45.00 \\
\hline $13 / 4$ & to & in.-_-n 6.50 & 50.00 \\
\hline 2 & $21 / 2$ & in.--n-- 7.50 & 65.00 \\
\hline $21 / 2$ & to & in._-_- 10.00 & 75.00 \\
\hline 3 & to $31 / 2$ & in..-_- 12.50 & \\
\hline
\end{tabular}

Tilia americana. American Linden.

\begin{tabular}{|c|c|c|}
\hline $11 / 4$ to & $11 / 2$ & in._-_- 4.50 \\
\hline $11 / 2$ to & $13 / 4$ & in.-_-_-_- \\
\hline $13 / 4$ to & 2 & in._- 6.50 \\
\hline to & $21 / 2$ & 7.50 \\
\hline $1 / 2$ & 3 & in. 10.00 \\
\hline
\end{tabular}

euchlora. Crimean Linden.

\begin{tabular}{|c|c|c|c|}
\hline & to & ft._-_- & 25.00 \\
\hline & to 10 & ft._--------- 3.75 & 5.00 \\
\hline $1 / 4$ & to $11 / 2$ & in..... 4.50 & $0 .($ \\
\hline & $13 / 4$ & in..-_- 5.00 & \\
\hline & to & in......- 6.50 & \\
\hline & to $2 \frac{1}{2}$ & in..-... 7.50 & 65.1 \\
\hline & to 3 & in.._. 10.00 & \\
\hline & Sil & er Linden. & \\
\hline & $11 / 2$ & in..--- & 45. \\
\hline & $13 / 4$ & in..- 6.50 & 50. \\
\hline & 2 & in..-n 7.50 & 65. \\
\hline & $2^{1 / 2}$ & in........ & 75. \\
\hline & $31 / 2$ & in.........- & \\
\hline & 4 & in.-..... & \\
\hline
\end{tabular}
platyphyllos. Bigleaf European Linden. 


\section{Tilia}

vulgaris. Common European Linden.

\begin{tabular}{|c|c|c|c|c|}
\hline & & ft $\quad$ each & per 10 & per 100 \\
\hline 6 & to & ft._-_-_-n- 2.75 & 25.00 & 225.00 \\
\hline 8 & to 10 & ft._. & 35.00 & 325.00 \\
\hline $11 / 4$ & to $11 / 2$ & in..-_-_- 4.50 & 40.00 & 375.00 \\
\hline $11 / 2$ & $13 / 4$ & in.--_- 5.00 & 45.00 & 400.00 \\
\hline $13 / 4$ & to & in.._- 6.50 & 50.00 & 475.00 \\
\hline 2 & $21 / 2$ & in..... 7.50 & 65.00 & 550.00 \\
\hline $21 / 2$ & to & in. & 75.00 & \\
\hline 3 & $31 / 2$ & in..... 12.50 & 100.00 & \\
\hline $31 / 2$ & to & in._- 17.50 & & \\
\hline
\end{tabular}

Ulmus americana. American Elm.

\begin{tabular}{|c|c|c|c|c|}
\hline 8 & 10 & ft._-_-n-- 3.25 & 25.00 & 200.00 \\
\hline $11 / 4$ & $11 / 2$ & in.-_- 3.50 & 27.50 & 250.00 \\
\hline $11 / 2$ & $13 / 4$ & in.-.- 4.50 & 37.50 & 325.00 \\
\hline $13 / 4$ & 2 & in._-_. 5.50 & 45.00 & 375.00 \\
\hline 2 & $21 / 2$ & in..-...- 7.50 & 55.00 & \\
\hline $21 / 2 \mathrm{t}$ & 3 & in. & 75.00 & \\
\hline
\end{tabular}

americana Moline. Moline Elm.

6 to $8 \mathrm{ft.}$
8 to $10 \mathrm{ft.}$ americana vase-shaped.

6 to 8 ft._-_-_-_-_-_-_ $3.00 \quad 25.00$ campestris. English Elm.

\begin{tabular}{|c|c|c|c|c|}
\hline & to & 8 & ft._. & 22.50 \\
\hline & to & 10 & ft._-_-_-_--- & 7. \\
\hline $1 / 4$ & to & $11 / 2$ & in.-_- & \\
\hline & to & $13 / 4$ & in._- 5.00 & \\
\hline & to & 2 & in._-_- 6.50 & o. \\
\hline & to & $21 / 2$ & in...... 7.50 & 5 \\
\hline & & 3 & in.. 10.00 & \\
\hline & to & $31 / 2$ & in..-_- 12.50 & 100. \\
\hline
\end{tabular}

campestris latifolia. Belgian Elm.

6 to $8 \mathrm{ft.}$

campestris monumentalis. Monument Elm.

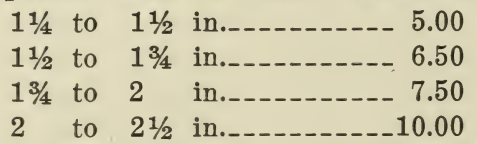

campestris purpurea. Purpleleaf English Elm.

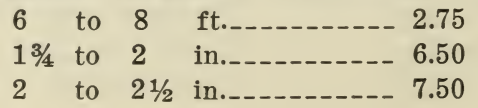




\section{Ulmus}

campestris vegeta. Huntingdon Elm.

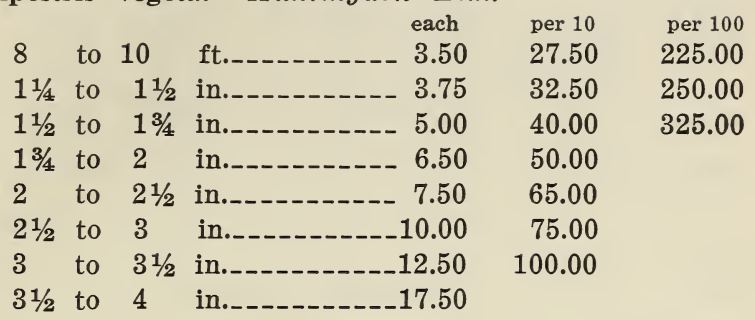

fulva. Slippery Elm.

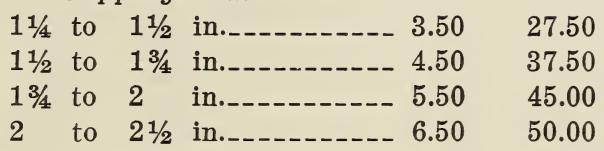

glabra. Scotch Elm.

\begin{tabular}{|c|c|c|c|c|}
\hline 8 & to 10 & ft.___-__n 3.50 & 27.50 & 225.00 \\
\hline $11 / 4$ & to $11 / 2$ & in._-_._- 3.75 & 32.50 & 250.00 \\
\hline $11 / 2$ & $13 / 4$ & in.___. 5.00 & 40.00 & 325.00 \\
\hline $13 / 4$ & 2 & in. & 50.00 & 375.00 \\
\hline & $21 / 2$ & in._- & 65.00 & \\
\hline $1 / 2$ & 3 & in. & 75.00 & \\
\hline & $31 / 2$ & in._-_- 12.50 & 100.00 & \\
\hline
\end{tabular}

japonica. Japanese Elm.

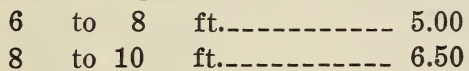

racemosa. Rock Elm.

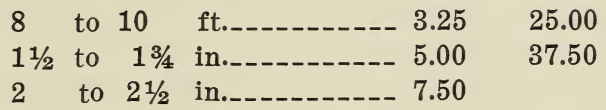

\section{Fruit Trees}

We are able to supply all the reading varieties.

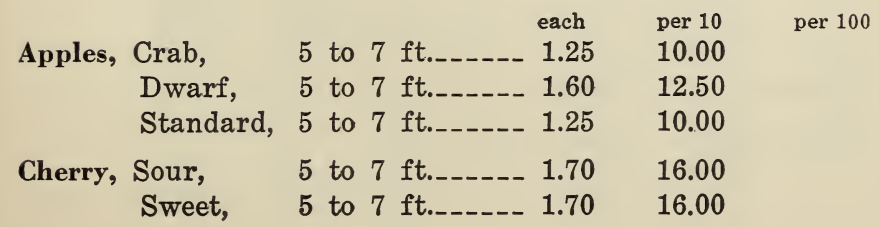




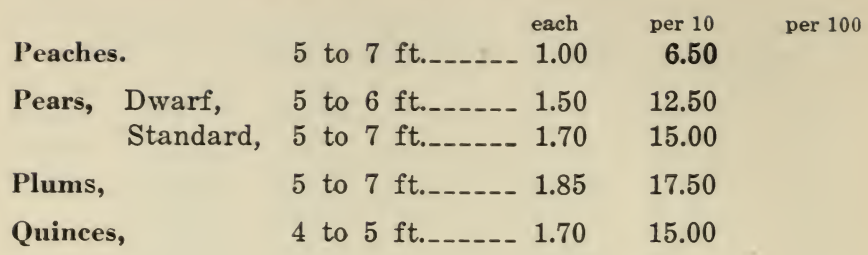

\section{Small Fruits}

Asparagus

Blackberries

1.00

9.50

Currants

Gooseberries .60

5.00

35.00

Grapes, 3 yr. strong

Raspberries

Rhubarb

Strawberries

\section{Deciduous Shrubs}

The figures printed in italics following each variety, indicate the average height of the plant at maturity.

Abelia rupestris grandiflora.

$$
\text { each }
$$

per 10

per 100

15 to 18 in. bushy

18 to 24 in. bushy 1.00

8.50

Acanthopanax pentaphyllum.

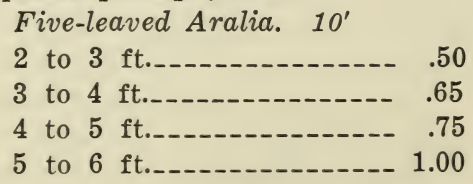

ricinifolium. Castor Aralia. 25'

$$
\begin{aligned}
8 \text { to } 10 \mathrm{ft.} & \\
10 \text { to } 12 \mathrm{ft.} &
\end{aligned}
$$

Althea. (See Hibiscus).

Alnus rugosa. Hazel Alder. 10'

$$
2 \text { to } 3 \text { ft._. } 3 \text { to } 4 \text { ft._. }
$$


Amelanchier canadensis. Downy Shadbush. 10'

\begin{tabular}{|c|c|c|c|c|}
\hline & & each & per 10 & per 100 \\
\hline & 3 ft.--n- & .60 & 4.50 & 40.00 \\
\hline 3 & $4 \mathrm{ft.}$ & .75 & 6.50 & 50.00 \\
\hline
\end{tabular}

laevis. Allegheny Serviceberry. 20'

2 to 3 ft.-_-_-_-_-_-_-_. .65

3 to $4 \mathrm{ft.}$.

vulgaris. European Serviceberry. 25'

2 to 3 ft.-.--_-_-_-_-_--- .65

3 to $4 \mathrm{ft.}$.

$6.50 \quad 50.00$

4 to 5 ft.-_-_-_-

Amorpha canescens. Lead Plant. 2'

15 to 18 in.................

18 to 24 in.-_-_-

fruticosa. Indigobush. 10'

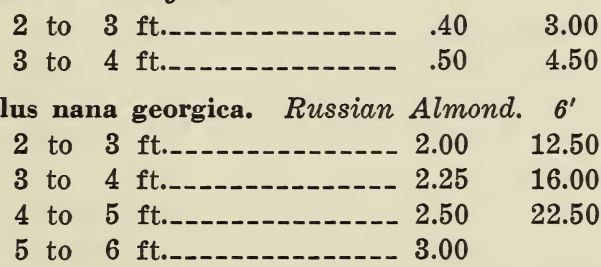

Aralia japonica. Angelica Tree. 25'

\begin{tabular}{|c|c|c|c|}
\hline 2 to & 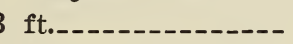 & .50 & 4.00 \\
\hline to & 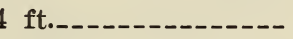 & .65 & 5.00 \\
\hline to & 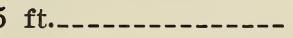 & .75 & 6.50 \\
\hline to & ft...-. & 1.25 & 10.00 \\
\hline to 8 & ft.----_- & 1.60 & 12.50 \\
\hline 8 to 10 & 0 ft._- & 3.75 & 32.50 \\
\hline
\end{tabular}

mandshurica. Manchurian Aralia. 25'

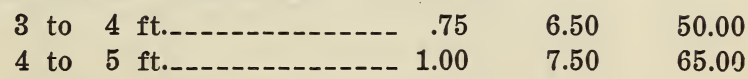

pentaphyllum. (See Acanthopanax).

spinosa. Devil's Walkingstick. 25'

2 to $3 \mathrm{ft.}$.

$4.50 \quad 40.00$

3 to 4 ft..-..-. 65

$5.50 \quad 50.00$

4 to $5 \mathrm{ft.}$._-_-_-_-_- 1.00

$7.50 \quad 60.00$

5 to $6 \mathrm{ft.}$

$10.00 \quad 80.00$

6 to $8 \mathrm{ft.}$

$12.50 \quad 100.00$

8 to $10 \mathrm{ft}$. clumps_-_-_-_- 5.00

10 to $12 \mathrm{ft}$. clumps_._..... 6.50 
Aronia arbutifolia. Red Chokeberry. $8^{\prime}$

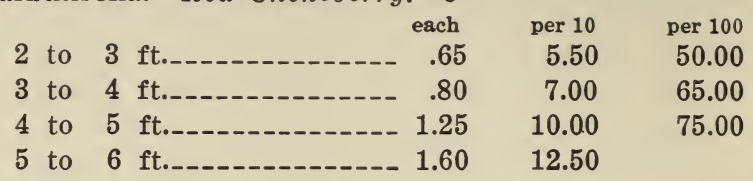

atropurpurea Purple Chokeberry. $8^{\prime}$

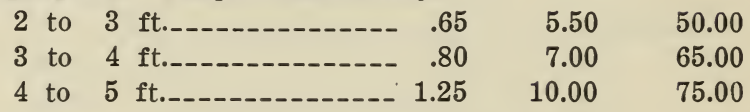

melanocarpa. Black Chokeberry. 10'

\begin{tabular}{|c|c|c|}
\hline to 3 & ft._--1 & 4.50 \\
\hline to & 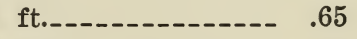 & 5.00 \\
\hline to & ft.--1.-15 & 5.50 \\
\hline to & ft._-_- & 7.50 \\
\hline
\end{tabular}

melanocarpa elata. Glossy Chokeberry. $6^{\prime}$

\begin{tabular}{|c|c|c|c|}
\hline 2 to & $3 \mathrm{ft.}$ & .60 & 4.50 \\
\hline to & 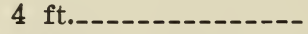 & .65 & 5.00 \\
\hline to & 5 ft._-------------- & .75 & 5.50 \\
\hline
\end{tabular}

Azalea calendulacea. Flame Azalea. $6^{\prime}$

2 to 3 ft._-_____B. \& B. $3.50 \quad 27.50 \quad 250.00$

canescens. Piedmont Azalea. $6^{\prime}$

2 to 3 ft.______B. \& B. $3.25 \quad 25.00 \quad 225.00$

nudiflora. Pinksterbloom. 4'

2 to 3 ft._-_____B. \& B. $3.25 \quad 25.00 \quad 225.00$

viscosa. Swamp Azalea. $6^{\prime}$

18 to 24 in._-_-__B. \& B. $2.50 \quad 22.50$

24 to 30 in._-_____B. \& B. $3.25 \quad 25.00$

225.00

Baccharis halimifolia. Groundselbush. 10'

\begin{tabular}{|c|c|c|}
\hline 2 to & 3 ft._-- & .60 \\
\hline to & -n-n-n-n-n & .75 \\
\hline to & $5 \mathrm{ft}$. & 1.00 \\
\hline
\end{tabular}

Benzoin aestivale. Spice Bush. 12'

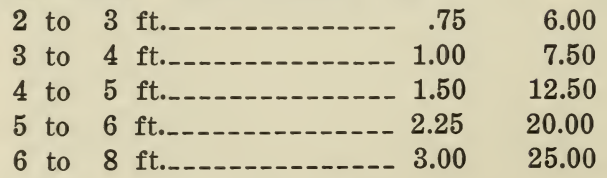

Berberis ilicifolia. Holly Barberry. 4'

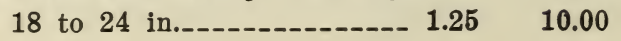


Berberis

thunbergi. Japanese Barberry. 4'

\begin{tabular}{|c|c|c|c|c|c|}
\hline & & & each & per 10 & per 100 \\
\hline 15 & to 18 & in......- & .30 & 2.00 & 15.00 \\
\hline 18 & to 24 & in. & .40 & 2.50 & 20.00 \\
\hline & to 30 & in........ & .50 & 4.00 & 30.00 \\
\hline 2 & $21 / 2$ & ft. specimens_- & .75 & 6.50 & \\
\hline $21 / 6$ & to & ft. specimens_- & 1.00 & 8.50 & \\
\hline & $31 / 2$ & ft. specimens_- & 1.25 & 11.50 & \\
\hline
\end{tabular}

thunbergi minor. Box Barberry.

12 to 15 in.................. .45

$4.00 \quad 30.00$

15 to 18 in..-..- .50

4.50

40.00

thunbergi pluriflora. $5^{\prime}$

\begin{tabular}{|c|c|c|c|}
\hline 18 & to 24 in. & .45 & 3.00 \\
\hline & in........... & .55 & 4.50 \\
\hline $21 / 2$ & to & .65 & 5.00 \\
\hline
\end{tabular}

Berchemia racemosa. Japanese Supplejack. 'З

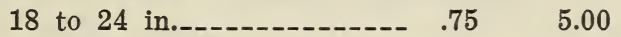

Buddleia davidi. Orange-eye Butterfly Bush. 5'

2 to 3 ft.-_-_-_-_-_-_-_ $.45 \quad 3.00$

25.00

3 to 4 ft._-_-_-_-_-_-_-_.-. $65 \quad 4.50$

30.00

davidi veitchi. Veitch Butterfly Bush. 5'

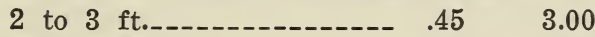

25.00

3 to $4 \mathrm{ft.}$.-.--

30.00

4 to $5 \mathrm{ft.}$.

intermedia. Wisteria Butterfly Bush. $5^{\prime}$

2 to $3 \mathrm{ft.} .--$

25.00

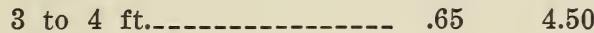

30.00

4 to 5 ft._-_-_-_-_-_-_- $.75 \quad 6.50$

lindleyana. Lindley Butterfly Bush. $5^{\prime}$

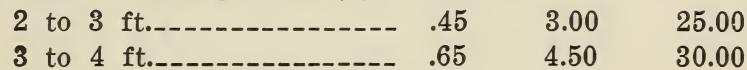

Callicarpa purpurea. Chinese Beautyberry. 4'

18 to 24 in.-_-_-_-_-_-_. $.50 \quad 4.00$

32.00

2 to $3 \mathrm{ft.}$.-_-_-_-_-_. $.65 \quad 5.00 \quad 45.00$

japonica. Japanese Beautyberry. $4^{\prime}$

18 to 24 in.-_-_-_._-_._- $.65 \quad 5.00$

45.00

Calycanthus floridus. Sweet Shrub. 5'

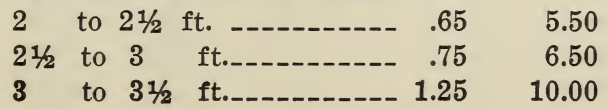


Caragana arborescens. Siberian Peatree. 15'

\begin{tabular}{|c|c|c|c|}
\hline & each & per 10 & per 100 \\
\hline 2 to $3 \mathrm{ft}$. & .50 & 4.00 & 25.00 \\
\hline 3 to $4 \mathrm{ft}$. & .65 & 4.50 & 30.00 \\
\hline 4 to 5 ft. & .75 & 6.50 & 50.00 \\
\hline to $6 \mathrm{ft}$. & 1.25 & 10.00 & \\
\hline
\end{tabular}

Caryopteris incana. Bluebeard. 4'

18 to 24 in.- 24 to 30 in.-

Ceanothus americanus. Jersey Tea. $\Im^{\prime}$

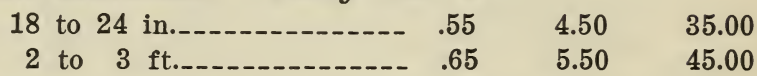

Cephalanthus occidentalis. Button Bush. $6^{\prime}$

\begin{tabular}{|c|c|c|}
\hline 2 to $3 \mathrm{ft}$. & .50 & 4.50 \\
\hline 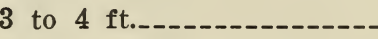 & .60 & 5.00 \\
\hline to $5 \mathrm{ft}$. & .75 & 6.00 \\
\hline
\end{tabular}

Chionanthus virginica. White Fringe. 25'

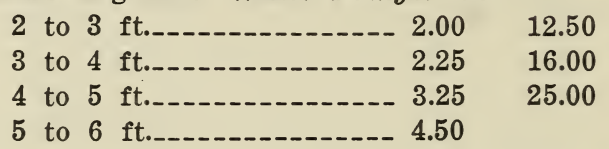

Clerodendron trichotomum. Harlequin Glorybower. $6^{\prime}$ 18 to 24 in......-..- $1.00 \quad 6.50$

2 to 3 ft._._-_._-_.-_ $1.25 \quad 10.00$

Clethra alnifolia. Sweet Pepper Bush. $5^{\prime}$

\begin{tabular}{|c|c|c|c|c|c|}
\hline 18 & to 24 & in.--.-- & .55 & 4.00 & 32.00 \\
\hline & 30 & - - - - - & .65 & 5.00 & 40.00 \\
\hline $21 / 2$ & to & ft._- & .75 & 5.50 & 50.00 \\
\hline
\end{tabular}

Colutea arborescens. Bladder Senna. 10'

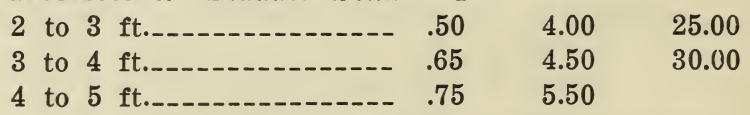

Comptonia asplenifolia. Sweetfern. $3^{\prime}$

$\begin{array}{rrrrr}18 \text { to } 24 \text { in... } & \\ 2 \text { to } 3 & \text { ft._. }\end{array}$

Cornus alba. Tatarian Dogwood. 10'

\begin{tabular}{|c|c|c|c|}
\hline 2 to $3 \mathrm{ft}$ & .45 & 3.00 & 20.00 \\
\hline to $4 \mathrm{ft}$. & .50 & 3.50 & 25.00 \\
\hline to $5 \mathrm{ft}$. & .65 & 5.00 & 40.00 \\
\hline to $6 \mathrm{ft}$. & .75 & 5.50 & 45.00 \\
\hline to $8 \mathrm{ft}$ & 1.00 & 6.50 & 50.00 \\
\hline
\end{tabular}




\section{Cornus}

alba elegantissima. Silverblotch Dogwood. 6'

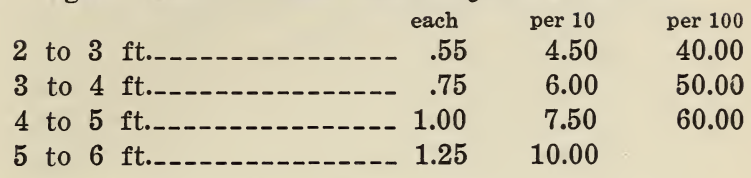

alba sibirica. Coral Dogwood.

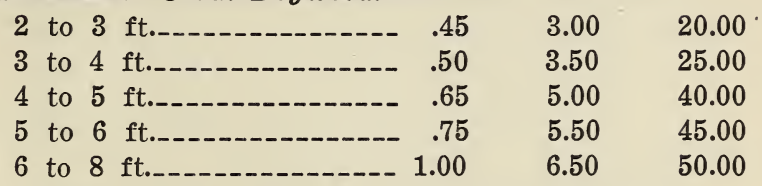

alba spaethi aurea. Golden variegated Dogwood. $8^{\prime}$

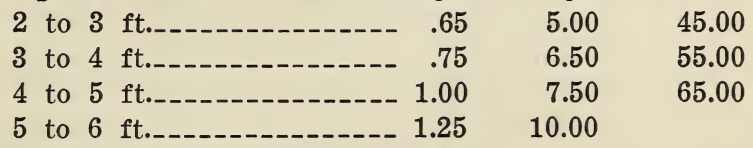

alternifolia. Pagoda Dogwood. 20'

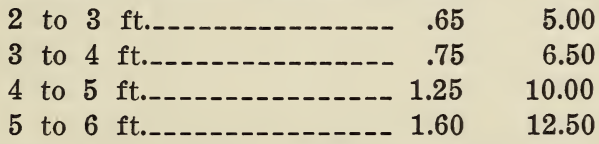

amomum syn. sericea. Silky Dogwood. 10'

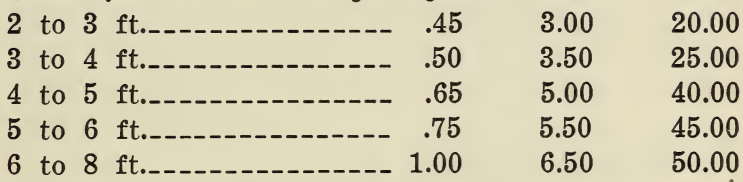

baileyi. Bailey Dogwood. 10'

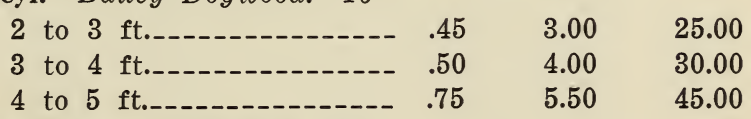

kousa. Kousa Dogwood. 20'

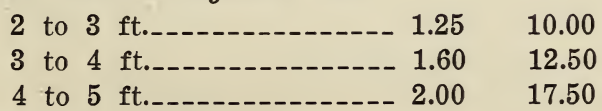

paniculata. Gray Dogwood. 15'

\begin{tabular}{|c|c|c|}
\hline 2 to $3 \mathrm{ft}$. & .50 & 4.00 \\
\hline 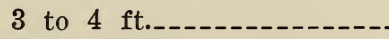 & .60 & 4.50 \\
\hline 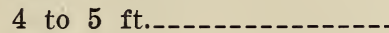 & .75 & 6.00 \\
\hline 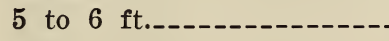 & 1.00 & 7.50 \\
\hline to $8 \mathrm{ft}$. & 1.25 & 9.00 \\
\hline
\end{tabular}




\section{Cornus.}

sanguinea. Bloodtwig Dogwood.

\begin{tabular}{|c|c|c|c|}
\hline & each & per 10 & per 100 \\
\hline 2 to $3 \mathrm{ft}$. & .45 & 3.00 & 20.00 \\
\hline 3 to $4 \mathrm{ft}$. & .50 & 3.50 & 25.00 \\
\hline 4 to $5 \mathrm{ft}$. & .60 & 5.00 & 40.00 \\
\hline to $6 \mathrm{ft}$. & .75 & 6.00 & 50.00 \\
\hline
\end{tabular}

sanguinea viridissima. Greentwig Dogwood. 10'

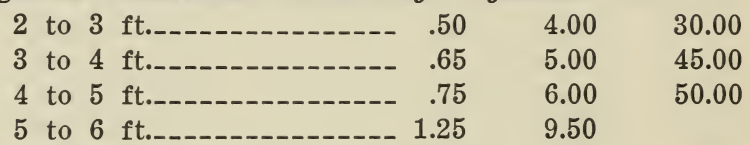

stolonifera. Red Osier Dogwood. $8^{\prime}$

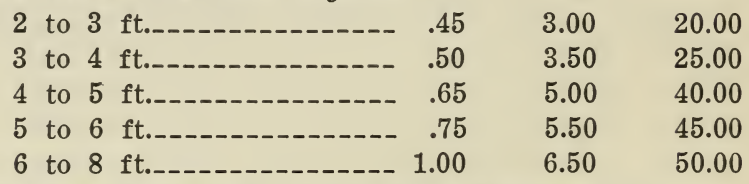

stolonifera flaviramea. Goldentwig Dogwood. $8^{\prime}$

\begin{tabular}{|c|c|c|}
\hline to $3 \mathrm{ft}$. & .45 & 3.50 \\
\hline to $4 \mathrm{ft}$. & .50 & 4.00 \\
\hline 4 to $5 \mathrm{ft}$ & .65 & 5.00 \\
\hline
\end{tabular}

Corylus americana. American Hazelnut. 10'

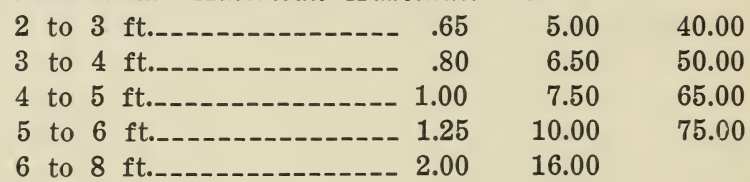

avellana. Filbert. $15^{\prime}$

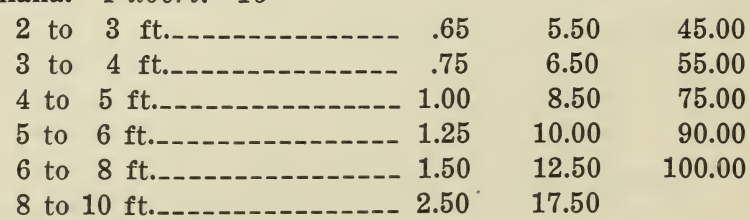

rostrata. Beaked Hazelnut. $6^{\prime}$

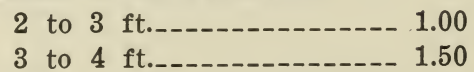

Cotoneaster acutifolia. Blackfruited Quinceberry. 12'

\begin{tabular}{|c|c|c|}
\hline 2 to $3 \mathrm{ft}$. & .50 & 4.00 \\
\hline $4 \mathrm{ft}$. & .60 & 4.50 \\
\hline ft.--_- & .75 & 5.50 \\
\hline to $6 \mathrm{ft}$. & 1.00 & 6.50 \\
\hline
\end{tabular}




\section{Cotoneaster}

adpressa. Creeping Cotoneaster. 2'

15 to 18 in._-____ \& B. $\begin{array}{lll}\text { each } & \text { per } 10 & \text { per } 100\end{array}$

applanata. $6^{\prime}$

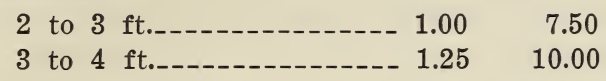

divaricata. Spreading Cotoneaster. $6^{\prime}$

2 to 3 ft.-_-_-_-_-_-_-_ $1.00 \quad 7.50$

3 to $4 \mathrm{ft.}$.-_-_-_-_-_-_.-_ $1.25 \quad 10.00$

foveolata. Scarlet fruited Quinceberry. 10'

2 to 3 ft.-_-_-_-_ $1.00 \quad 7.50$

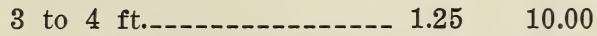

horizontalis. Prostrate Quinceberry. $3^{\prime}$

15 to 18 in. spread__B. \& B. $1.50 \quad 12.50$

18 to 24 in. spread__B. \& B. $2.00 \quad 16.00$

hupehensis. Hupen Cotoneaster. $5^{\prime}$

2 to 3 ft.----_---_---_--- $1.25 \quad 10.00$

3 to 4 ft._-_-_-_-_-_-_-_- $1.50 \quad 12.50$

75.00

lucida. $12^{\prime}$

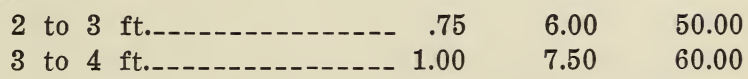

nitens. $6^{\prime}$

2 to 3 ft.-_-_- $1.00 \quad 7.50 \quad 65.00$

3 to $4 \mathrm{ft.}$

obscura. $10^{\prime}$

2 to 3 ft.-_-_-_-_-_-_- $1.00 \quad 7.50$

65.00

3 to $4 \mathrm{ft.}$.-_-_-_-_-_-_-_ $1.25 \quad 10.00$

wilsoni. Wilson Cotoneaster. $5^{\prime}$

2 to 3 ft._-_-_-_-_- $1.00 \quad 7.50$

3 to 4 ft._-_-_-_-_-_-_-_-_ $1.25 \quad 10.00$

75.00

Cydonia japonica. Flowering Quince. $5^{\prime}$

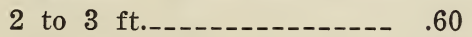

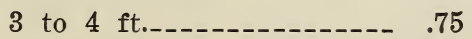

japonica umbilicata. Naval Flowering Quince. 5' $^{\prime}$

2 to 3 ft._-_-_-_-_-_- $.75 \quad 6.50 \quad 50.00$

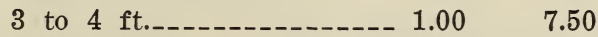

4 to $5 \mathrm{ft.}$._-_._-_-_-_._- $1.25 \quad 10.00$

maulei. Lesser Flowering Quince. $5^{\prime}$

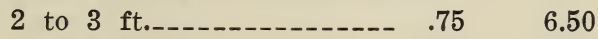

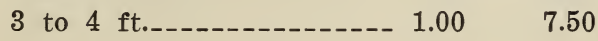


Cytisus hirsutus. 3

each per 10

per 100

2 to $3 \mathrm{ft}$.

4.00

Daphne mezereum. February Daphne. 4'

15 to 18 in..._._._. B. B. 1.50

Desmodium. (See Lespedeza).

Deutzia gracilis. Slender Deutzia. $3^{\prime}$

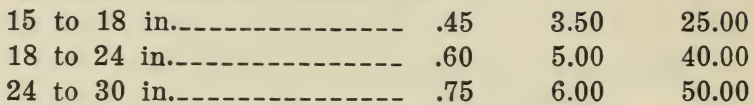

gracilis campanulata. Bellflower Deutzia. $5^{\prime}$

18 to 24 in..-_.-.-. $.50 \quad 4.50$

40.00

24 to 30 in.._-_._-_._- $.60 \quad 5.50$

50.00

$21 / 2$ to 3 ft._-___-_._-_. $.75 \quad 7.00$

60.00

3 to $4 \mathrm{ft.}$

7.50

gracilis carminea. Carmine Deutzia. $4^{\prime}$

18 to 24 in.-. $\quad .65 \quad 5.50$

50.00

2 to

.75

7.00

60.00

3 to $4 \mathrm{ft}$.

7.50

70.00

gracilis rosea. Rose-panicle Deutzia. 4'

18 to 24 in..-_-_-_-_- .65 5.50

50.00

24 to 30 in.._-_._- .75

7.00

60.00

$21 / 2$ to 3 ft.-_-_-_-_-_- .85

7.50

65.00

3 to $4 \mathrm{ft.}$

gracilis venusta. White-panicle Deutzia. 5'

18 to 24 in. $50 \quad 4.50$

24 to 30 in....... $.60 \quad 5.50$

$21 / 2$ to $3 \mathrm{ft.}$.

3 to $4 \mathrm{ft}$...- $1.00 \quad 7.50$

lemoinei. Lemoine Deutzia. 5'

18 to 24 in.-_-_._- $.50 \quad 4.00$

5.00

24 to 30 in.-.-.-.-.-- .65

6.00

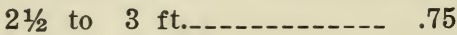

3 to 4 ft._-__-__-_ $1.00 \quad 8.00$

lemoine avalanche. Avalanche Deutzia. 4'

2 to $2 \frac{1}{2}$ ft._._._._._._. $.75 \quad 6.00$

$21 / 2$ to 3 ft._._.-...- $1.00 \quad 7.50$

parviflora. Mongolian Deutzia. '5'

18 to 24 in................ .60

5.00

40.00 50.00 60.00

2 to 3 ft.-_-_-_-_-_-_-- .75

6.00

40.00 50.00

scabra. Fuzzy Deutzia. 12'

2 to $3 \mathrm{ft}$.

.45

3.50

25.00

3 to $4 \mathrm{ft.}$._-_-_-_-_-_- .50

4.00

30.00

4 to 5 ft._._-_-_-_-_- .65

5.00

40.00

5 to $6 \mathrm{ft}$

5.50

50.00 


\section{Deutzia}

scabra candidissima. Snowflake Deutzia. 12'

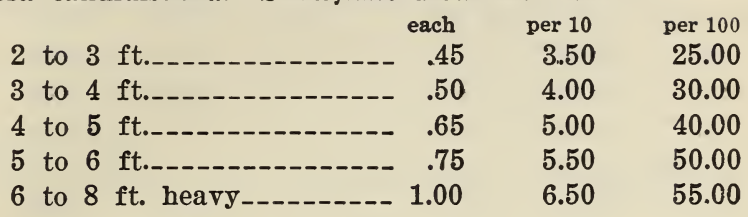

scabra Pride of Rochester. 12'

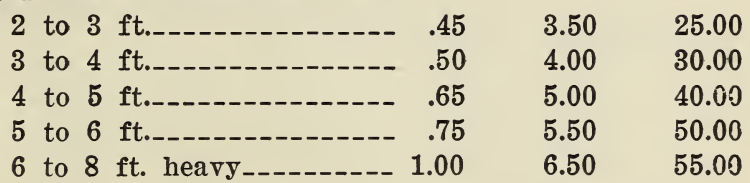

scabra rosea plena. $12^{\prime}$

\begin{tabular}{|c|c|c|c|}
\hline 2 to $3 \mathrm{ft}$. & .45 & 3.50 & 25.00 \\
\hline to $4 \mathrm{ft.}$ & .50 & 4.00 & 30.00 \\
\hline to $5 \mathrm{ft}$. & .65 & 5.00 & 40.00 \\
\hline 5 to 6 ft. & .75 & 6.00 & 50.00 \\
\hline
\end{tabular}

scabra watereri. Waterer's Deutzia. 12'

\begin{tabular}{|c|c|c|c|}
\hline 2 to $3 \mathrm{ft}$. & .45 & 3.50 & 25.00 \\
\hline to $4 \mathrm{ft}$. & .50 & 4.00 & 30.00 \\
\hline to $5 \mathrm{ft}$. & .65 & 5.00 & 40.00 \\
\hline 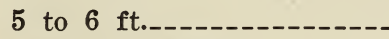 & .75 & 5.50 & 50.00 \\
\hline to $8 \mathrm{ft}$. heary & 1.00 & 6.50 & 55.00 \\
\hline
\end{tabular}

vilmorinae. Vilmorin Deutzia. 10'

3 to $4 \mathrm{ft.}$.

4 to $5 \mathrm{ft}$.

Diervilla sessilifolia. Southern Bush Honeysuckle. 5'

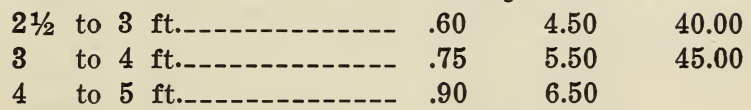

trifida. Dwarf Bush Honeysuckle. 3'

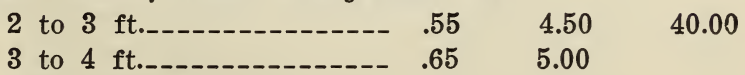

(See also Weigela)

Elaeagnus angustifolia. Russian Olive. 20'

\begin{tabular}{|c|c|c|}
\hline to $4 \mathrm{ft}$. & .60 & 4.50 \\
\hline 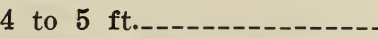 & .75 & 5.50 \\
\hline to $6 \mathrm{ft}$. & 1.00 & 7.50 \\
\hline ft._--- - - - - - - - & 1.25 & 10.00 \\
\hline
\end{tabular}




\section{Euonymus}

latifolius. Broadleaf Burning Bush. 10'

$$
\begin{aligned}
& 3 \text { to } 4 \text { ft._-_-_-_-_- } 75 \quad 6.50 \\
& 4 \text { to } 5 \mathrm{ft.} \text {._-_-_-_-_-_-_ } 1.00 \quad 7.50
\end{aligned}
$$

maacki. $10^{\prime}$

$\begin{array}{rrrr}18 \text { to } 24 \text { in } & \text { in } 3 \text { to } 3 \text { ft.- }\end{array}$

\begin{tabular}{|c|c|}
\hline 2 to $3 \mathrm{ft}$. & 6.00 \\
\hline to $4 \mathrm{ft}$. & 7.50 \\
\hline to $5 \mathrm{ft}$. & 10.00 \\
\hline to $6 \mathrm{ft}$. & 12.50 \\
\hline
\end{tabular}

yedoensis. Yeddo Euonymus. 10'

Exochorda grandiflora. Pearl Bush. 10'

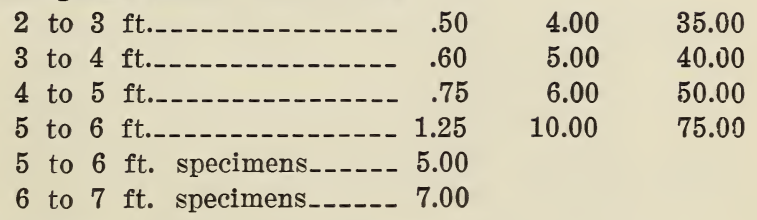

Fontanesia fortunei. Fortune Fontanesia. 15'

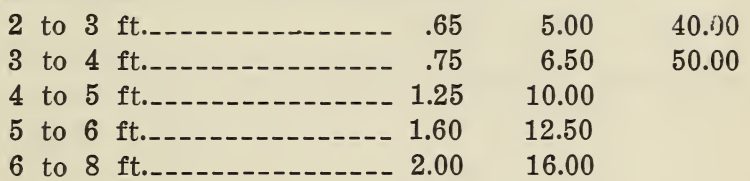

\begin{tabular}{|c|c|c|}
\hline 2 to $3 \mathrm{ft}$. & .45 & 3.50 \\
\hline to $4 \mathrm{ft}$. & .50 & 4.00 \\
\hline to $5 \mathrm{ft}$. & .65 & 5.00 \\
\hline to $6 \mathrm{ft.}$ & .75 & 6.50 \\
\hline to $7 \mathrm{ft.}$. & 1.25 & 10.00 \\
\hline
\end{tabular}

Forsythia intermedia. Border Forsythia. $8^{\prime}$

\begin{tabular}{|c|c|c|}
\hline 2 to $3 \mathrm{ft}$. & .45 & 3.50 \\
\hline to $4 \mathrm{ft}$. & .50 & 4.00 \\
\hline to $5 \mathrm{ft.}$ & .65 & 5.00 \\
\hline to $6 \mathrm{ft}$. & .75 & 6.50 \\
\hline
\end{tabular}

intermedia spectabilis. Showy Border Forsythia. $8^{\prime}$

suspensa. Weeping Forsythia.

2 to 3 ft.--_-_-_-_-- $.50 \quad 4.00 \quad 30.00$

3 to 4 ft._._-_-_-_-_._- $.65 \quad 5.00 \quad 40.00$ 


\section{Forsythia}

suspensa atrocaulis. Purple stem Forsythia. $6^{\prime}$

$$
\begin{aligned}
& 2 \text { to } 3 \text { ft._-_-_-_-_-_-_ } \quad .75 \quad 6.00 \\
& 3 \text { to } 4 \mathrm{ft.} \text {._-_-_-_-_-_-_ } 1.00 \quad 8.50
\end{aligned}
$$

\begin{tabular}{|c|c|c|}
\hline to $3 \mathrm{ft}$. & .45 & 3.00 \\
\hline $4 \mathrm{ft}$. & .50 & 4.00 \\
\hline 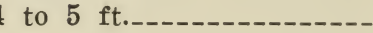 & .65 & 5.00 \\
\hline ft..-. & .75 & 6.50 \\
\hline
\end{tabular}

suspensa fortunei. Golden Bell. $8^{\prime}$

\begin{tabular}{|c|c|c|}
\hline 2 to $3 \mathrm{ft}$. & .45 & 3.00 \\
\hline to $4 \mathrm{ft}$. & .50 & 4.00 \\
\hline 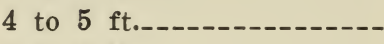 & .65 & 5.00 \\
\hline to $6 \mathrm{ft}$. & .75 & 6.50 \\
\hline
\end{tabular}

suspensa sieboldi. Siebold Forsythia.

\begin{tabular}{|c|c|c|}
\hline to st $2+5$ & .45 & 3.50 \\
\hline to $4 \mathrm{ft}$. & .50 & 4.00 \\
\hline to $5 \mathrm{ft}$. & .65 & 5.00 \\
\hline
\end{tabular}

viridissima. Greenstem Forsythia. $8^{\prime}$

Genista tinctoria. Woadwaxen. 3'

$$
\begin{aligned}
& 2 \text { to } 3 \text { ft.-_-_-_-_-_-_- } .60 \quad 5.00 \\
& 3 \text { to } 4 \mathrm{ft.}
\end{aligned}
$$

Halesia. (See Trees).

Hamamelis virginiana. Witch Hazel. 15'

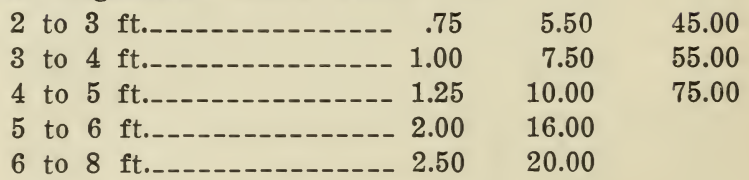

japonica. Japanese Witch Hazel. $8^{\prime}$

$$
\begin{aligned}
& 2 \text { to } 3 \text { ft._-_-_-_-_-_-_-_- } 1.25 \\
& 3 \text { to } 4 \mathrm{ft} . \\
& 4 \text { to } 5 \mathrm{ft.} .
\end{aligned}
$$

Hibiscus syriacus. Shrub Althea. 12'

double varieties.

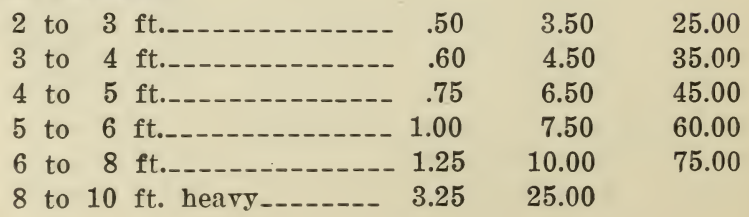


Hibiscus-Double Varieties.

Ardens-Purple.

Banner-Blush.

Jeanne d'Arc-White.

Lady Stanley-White, shaded rose.

Rubra Plena-Red.

Speciosa Plena-Pink.

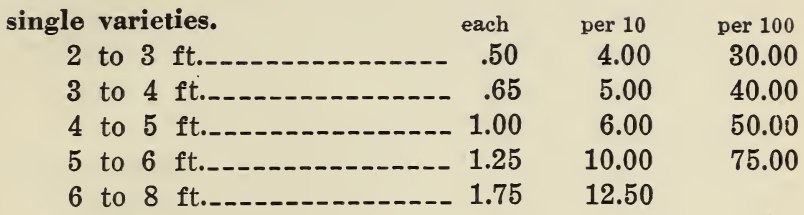

Coelestis-Blue.

Rosea-White, crimson eye.

Rubis-Red.

Totus albus-White.

variegatus. Variegated leaved Althea. 8'

2 to 3 ft...............- $1.00 \quad 7.50$

3 to $4 \mathrm{ft.}$

variegatus meehani. Meehan's Variegated Althea. $6^{\prime}$

2 to 3 ft._._._._._._. $1.00 \quad 7.50$

Hippophae rhamnoides. Sea-buckthorn. 12'

2 to 3 ft._._-_._.-. $75 \quad 6.50$ 50.00

Hovenia dulcis. Raisintree. $6^{\prime}$

18 to 24 in.-.
2 to 3 ft._.

Hydrangea arborescens. Smooth Hydrangea. $6^{\prime}$

2 to $3 \mathrm{ft.}$
3 to $4 \mathrm{ft.}-\ldots .000$

arborescens grandiflora. Snowhill Hydrangea. $6^{\prime}$

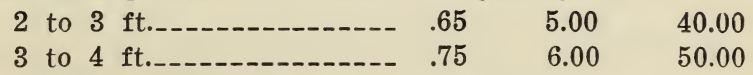

cineria sterilis. Ashy Hydrangea. $6^{\prime}$

2 to 3 ft.-... .75

$6.00 \quad 50.00$

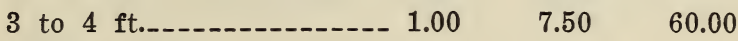

opuloides Otaksa.

4 year -_-_-_-_-_-_- $1.00 \quad 7.50$

opuloides Thos. Hogg.

4 year 


\section{Hydrangea.}

paniculata. Panicle Hydrangea. 10'

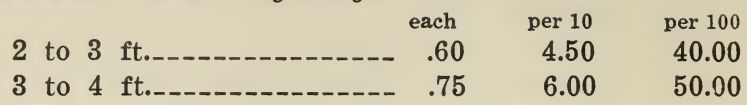

paniculata grandiflora. Peegee Hydrangea. 10'

\begin{tabular}{|c|c|c|}
\hline 2 to $3 \mathrm{ft}$. & .60 & 4.50 \\
\hline to $4 \mathrm{ft}$. & .75 & 6.00 \\
\hline to $4 \mathrm{ft}$. tree form & 1.25 & 10.00 \\
\hline to $5 \mathrm{ft}$. tree form & 1.60 & 12.50 \\
\hline
\end{tabular}

quercifolia. Oakleaf Hydrangea. 4'

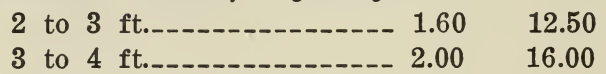

radiata. Silverleaf Hydrangea. $6^{\prime}$

2 to 3 ft._. 3 to 4 ft._.

Hypericum aureum. Golden St. Johnswort. 4'

18 to 24 in......... $.50 \quad 4.00$

2 to $3 \mathrm{ft.}$.

calycinum. (See Perennials).

densiflorum. $5^{\prime}$

18 to 24 in.-_-_-_-_-_- $.50 \quad 4.00$

2 to $3 \mathrm{ft.}$.

moserianum. Goldflower. $2^{\prime}$

15 to 18 in.._-_._- $.50 \quad 4.50$

40.00

18 to 24 in.-_- $65 \quad 5.00 \quad 45.00$

patulum henryi. Henry Hypericum. 4'

18 to 24 in..-_-_-_-_-_- $.50 \quad 4.50$

40.00

2 to $3 \mathrm{ft.}$.

prolificum. Shrubby St. Johnswort. 5'

18 to 24 in.._-_._. $50 \quad 4.00$

Ilex monticola. Mountain Winterberry. 10'

2 to 3 ft._-__-_-_._-_._- $.75 \quad 6.50$

3 to $4 \mathrm{ft.}$

verticillata. Common Winterberry. $6^{\prime}$

2 to 3 ft.-_-_-_-_.- $.75 \quad 6.00 \quad 50.00$

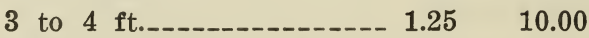

Itea virginica. Sweetspire. $\boldsymbol{S}^{\prime}$

2 to 3 ft._._-_._-

3 to $4 \mathrm{ft.}$ 
Jasminum nudiflorum. Winter Jasmine. $3^{\prime}$

\begin{tabular}{|c|c|c|c|}
\hline & each & per 10 & per 100 \\
\hline 15 to 18 in. & .65 & 4.50 & 40.00 \\
\hline 18 to 24 & .75 & 5.50 & 50.00 \\
\hline
\end{tabular}

Kerria japonica. Kerria.

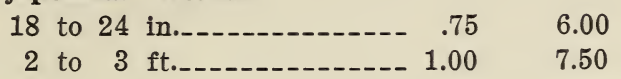

japonica florepleno. Double Kerria.

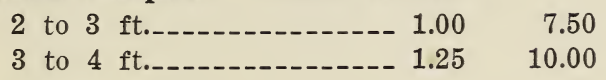

Lespedeza bicolor. Shrub Bushclover. $6^{\prime}$

$\begin{array}{lrrr}2 \text { to } 3 \mathrm{ft} . & .60 & 4.50 & 40.00 \\ 3 \text { to } 4 \mathrm{ft.} & \end{array}$

formosa, syn. penduliflorum. Purple Bushclover. 4'

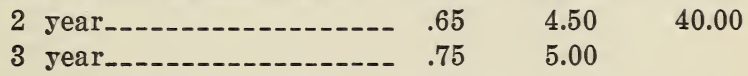

formosa albiflora. Japanese Bushclover. $5^{\prime}$

2 jear-_-_-_-_-_-_-_- $.65 \quad 5.00 \quad 40.90$

Ligustrum acuminatum. 10'

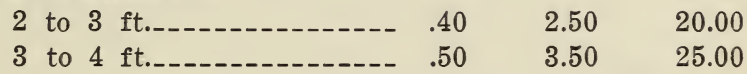

acuminatum macrocarpum. Bigberry Privet. 10'

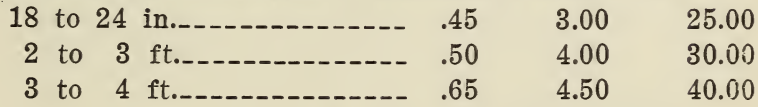

amurense. Amur Privet. 15'

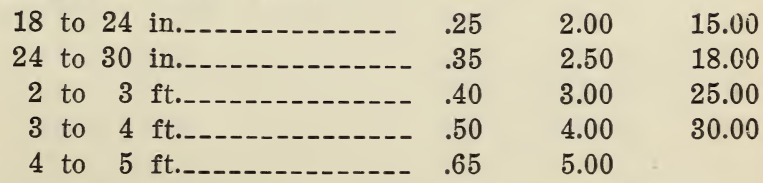

ibolium. Ibolium Privet.

$\begin{array}{rrrrr}18 \text { to } 24 \text { in.-. } & \\ 2 \text { to } 3 \text { ft._- }\end{array}$

ibota. Ibota Privet. 10'

\begin{tabular}{|c|c|c|c|}
\hline 2 to $3 \mathrm{ft}$. & .40 & 2.50 & 20.00 \\
\hline to $4 \mathrm{ft}$. & .50 & 3.00 & 25.00 \\
\hline to $5 \mathrm{ft}$. & .60 & 5.00 & 40.00 \\
\hline
\end{tabular}




\section{Ligustrum}

ibota nanum. Pygmy Privet.

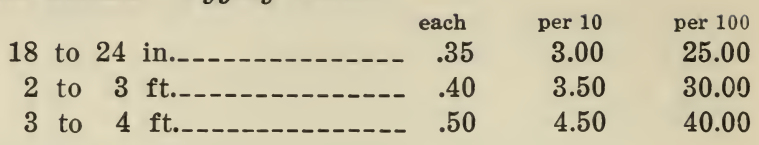

ibota regelianum. Regel Privet.

$\begin{array}{cllrll}18 & \text { to } 24 & \text { in. } \text { spread_-_- } & .50 & 4.00 & 30.00 \\ 24 & \text { to } 30 & \text { in. spread_--- } & .65 & 4.50 & 35.00 \\ 21 / 2 & \text { to } 3 & \text { ft. } \text { spread_--- } & .75 & 6.00 & 45.00 \\ 3 & \text { to } 31 / 2 & \text { ft. } \text { spread_--- } & 1.00 & 7.50 & 65.00\end{array}$

lodense. Dwarf Privet. 21/2'

12 to 15 in.-- 15 to 18 in.-_-

ovalifolium. California Privet. 10'

18 to 24 in..._._. $20 \quad 1.00 \quad 6.50$

24 to 30 in

3 to $4 \mathrm{ft.}$.-_-_- 3.50

ovalifolium variegatum. Golden Privet. 10'

2 to 3 ft._-_-_-_-_-_-_. $.50 \quad 4.50$

3 to $4 \mathrm{ft.}$

vulgare. European Privet. 12'

\begin{tabular}{|c|c|c|}
\hline to $3 \mathrm{ft}$. & .45 & 3.50 \\
\hline to $4 \mathrm{ft}$. & .50 & 4.00 \\
\hline to $5 \mathrm{ft}$. & .60 & 4.50 \\
\hline
\end{tabular}

vulgare foliosum. $10^{\prime}$

2 to 3 ft.-_-_-_-_-_-_-_. $.50 \quad 3.50$

vulgare leucocarpum. Yellowberry Privet.

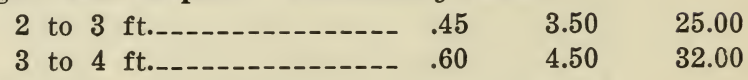

Lindera benzoin. (See Benzoin aestivale).

Lonicera bella albida. White Belle Honeysuckle. 10'

\begin{tabular}{|c|c|c|c|}
\hline 2 to $3 \mathrm{ft}$. & .45 & 3.50 & 25.00 \\
\hline $4 \mathrm{ft.}$ & .50 & 4.00 & 30.00 \\
\hline to $5 \mathrm{ft}$. & .65 & 5.00 & 40.00 \\
\hline to 6 & .75 & 5.50 & 45.00 \\
\hline to $8 \mathrm{ft}$. & 1.00 & 7.50 & 60.00 \\
\hline
\end{tabular}




\section{Lonicera}

bella rosea. Belle Honeysuckle. 10'

\begin{tabular}{|c|c|c|c|}
\hline & each & per 10 & per 100 \\
\hline 2 to $3 \mathrm{ft}$. & .45 & 3.50 & 25.00 \\
\hline to $4 \mathrm{ft}$. & .50 & 4.00 & 30.00 \\
\hline to $5 \mathrm{ft}$. & .65 & 5.00 & 40.00 \\
\hline
\end{tabular}

billardi. $\quad 8^{\prime}$

\begin{tabular}{|c|c|c|}
\hline 2 to $3 \mathrm{ft}$. & .45 & 3.50 \\
\hline $4 \mathrm{ft.}$ & .50 & 4.00 \\
\hline to $5 \mathrm{ft.}$ & .60 & 5.00 \\
\hline 5 to $6 \mathrm{ft} . \ldots$ & .75 & 6.50 \\
\hline
\end{tabular}

chrysantha. Coralline Honeysuckle. 10'

\begin{tabular}{|c|c|c|}
\hline 2 to $3 \mathrm{ft}$ & .50 & 4.00 \\
\hline to $4 \mathrm{ft}$. & .60 & 4.50 \\
\hline to $5 \mathrm{ft}$. & .65 & 5.00 \\
\hline 5 to $6 \mathrm{ft}$ & .75 & 6.50 \\
\hline
\end{tabular}

conjugalis. $8^{\prime}$

\begin{tabular}{|c|c|c|}
\hline 3 to $4 \mathrm{ft}$. & .50 & 4.50 \\
\hline ft..---_- & .65 & 5.00 \\
\hline to $6 \mathrm{ft}$. & .75 & 6.50 \\
\hline
\end{tabular}

fragrantissima. Winter Honeysuckle. $8^{\prime}$

3 to $4 \mathrm{ft} . \ldots$. 35.00

gracilipes. Spangled Honeysuckle. $6^{\prime}$

\begin{tabular}{|c|c|c|}
\hline 2 to $3 \mathrm{ft}$. & .50 & 3.50 \\
\hline to $4 \mathrm{ft}$ & .60 & 4.50 \\
\hline to $5 \mathrm{ft}$ & .65 & 5.00 \\
\hline 5 to $6 \mathrm{ft}$.- & .80 & 7.00 \\
\hline
\end{tabular}

kesselringi. Black fruited Honeysuckle. 10' 3 to 4 ft._._._._._._._.-. $.60 \quad 4.50$

4 to 5 ft._._-_._- $\quad .65 \quad 5.00$

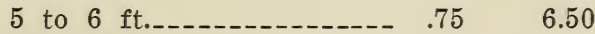

korolkowi floribunda.

Broad Blueleaf Honeysuckle. 10'

2 to 3 ft.-._-_-_-_-_._. $.65 \quad 5.00$

45.00

3 to 4 ft.._-_-_-_-_._-_. $.75 \quad 6.50$

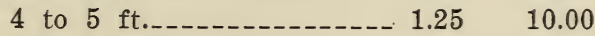

ledebouri.

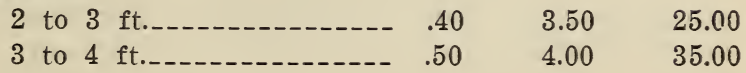




\section{Lonicera}

maacki. Amur Honeysuckle. 10'

\begin{tabular}{|c|c|c|c|}
\hline & each & per 10 & per 100 \\
\hline 3 to $4 \mathrm{ft}$. & -.60 & 4.50 & 35.00 \\
\hline to $5 \mathrm{ft}$. & .75 & 5.50 & 45.01 \\
\hline 5 to $6 \mathrm{ft}$. & -1.00 & 7.50 & 60.00 \\
\hline 6 to $7 \mathrm{ft.}$ & -1.25 & 1 & \\
\hline
\end{tabular}

morrowi. Japanese Bush Honeysuckle. $8^{\prime}$

\begin{tabular}{|c|c|c|}
\hline to $3 \mathrm{ft}$. & .45 & 3.50 \\
\hline to $4 \mathrm{ft}$. & .50 & 4.00 \\
\hline to $5 \mathrm{ft}$. & .65 & 5.00 \\
\hline to $6 \mathrm{ft}$. & .75 & 6.50 \\
\hline
\end{tabular}

morrowi. (Yellow Fruited). $8^{\prime}$

\begin{tabular}{|c|c|c|}
\hline 2 to $3 \mathrm{ft}$. & .45 & 3.50 \\
\hline to $4 \mathrm{ft}$. & .50 & 4.00 \\
\hline to $5 \mathrm{ft}$. & .65 & 5.00 \\
\hline 5 to $6 \mathrm{ft}$. & .75 & 6.50 \\
\hline
\end{tabular}

muendeniensis. Muenden Honeysuckle. $8^{\prime}$

\begin{tabular}{|c|c|c|}
\hline 2 to $3 \mathrm{ft}$. & .45 & 3.50 \\
\hline to $4 \mathrm{ft}$. & .50 & 4.00 \\
\hline to $5 \mathrm{ft}$. & .65 & 5.50 \\
\hline 5 to $6 \mathrm{ft}$ & .75 & 6.00 \\
\hline
\end{tabular}

pileata. Privet Honeysuckle. 2'

6 to 12 in.-_-_-_._- $.50 \quad 4.00 \quad 35.00$

quinquelocularis. Mistletoe Honeysuckle. 10'

3 to $4 \mathrm{ft.}$ f._-_-_-_-_-_- $.65 \quad 5.00$

4 to $5 \mathrm{ft.}$

ruprechtiana. Manchurian Honeysuckle. 10'

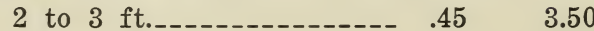

25.00

3 to $4 \mathrm{ft.}$ t.-_-_-_-_-_.-. $.50 \quad 4.00$

4 to $5 \mathrm{ft.}$

30.00

5 to $6 \mathrm{ft.} .-\ldots$

6.00

40.00

50.00

spinosa alberti. Thorn Honeysuckle. 2'

\begin{tabular}{|c|c|c|}
\hline to 15 in. & .50 & 4.50 \\
\hline 15 to 18 in. & .65 & 5.00 \\
\hline to 24 in. & .75 & 6.00 \\
\hline
\end{tabular}

standishi. $5^{\prime}$

3 to $4 \mathrm{ft.}$.

syringantha. Lilac Honeysuckle.

18 to 24 in.-_-_-_-_-_-_ $.75 \quad 6.00$ 


\section{Lonicera}

tatarica. Red Tatarian Honeysuckle. 10'

\begin{tabular}{|c|c|c|c|}
\hline & each & per 10 & per 100 \\
\hline 2 to $3 \mathrm{ft}$. & .45 & 3.00 & 25.00 \\
\hline 3 to $4 \mathrm{ft}$. & .50 & 4.00 & 30.00 \\
\hline 4 to $5 \mathrm{ft}$. & .65 & 5.00 & 45.00 \\
\hline to $6 \mathrm{ft}$. & .75 & 6.00 & 50.00 \\
\hline to $7 \mathrm{ft}$. & 1.25 & 9.00 & 75.00 \\
\hline
\end{tabular}

tatarica alba. White Tatarnan Honeysuckle. 10'

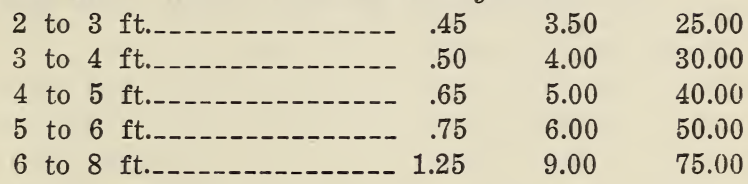

tatarica grandiflora. Pink Tatarian Honeysuckle. 10'

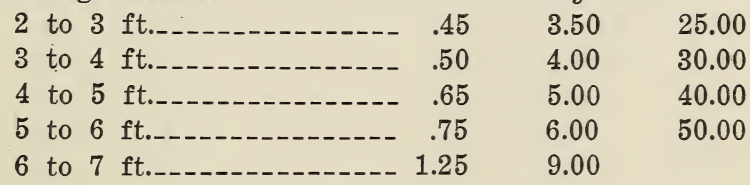

translucens. White-fruited Honeysuckle. 10'

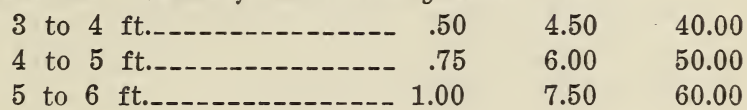

virginalis alba. Maiden Honeysuckle. 10'

\begin{tabular}{|c|c|c|}
\hline 2 to $3 \mathrm{ft}$. & .45 & 3.00 \\
\hline to $4 \mathrm{ft}$. & .50 & 4.00 \\
\hline to $5 \mathrm{ft}$. & .65 & 5.00 \\
\hline
\end{tabular}

xylosteum. Fly Honeysuckle. 8'

\begin{tabular}{|c|c|c|}
\hline 2 to $3 \mathrm{ft}$. & .45 & 3.50 \\
\hline to $4 \mathrm{ft}$. & .50 & 4.00 \\
\hline to $5 \mathrm{ft}$. & .65 & 5.00 \\
\hline to $6 \mathrm{ft}$. & .75 & 5.50 \\
\hline
\end{tabular}

Lycium chinense. Chinese Matrimony Vine. $5^{\prime}$

\begin{tabular}{|c|c|c|}
\hline 2 to $3 \mathrm{ft}$. & .35 & 2.50 \\
\hline to $4 \mathrm{ft.}$ & .45 & 3.00 \\
\hline to $5 \mathrm{ft}$. & .50 & 4.00 \\
\hline
\end{tabular}

halimifolium. Common Matrimony Vine.

2 to $3 \mathrm{ft.}$
3 to $4 \mathrm{ft.}-\ldots$


Myrica cerifera. Southern Waxmyrtle. 5'

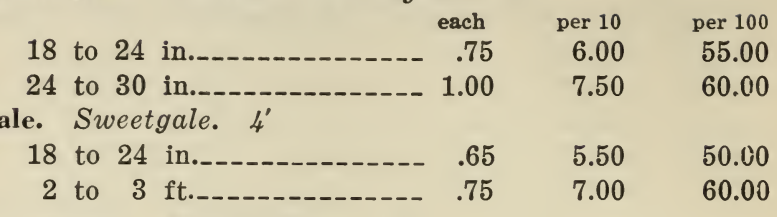

Neillia sinensis. Tube Neillia. 4'

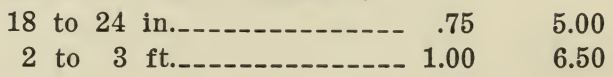

Oxydendrum arboreum. Sourwood. 40'

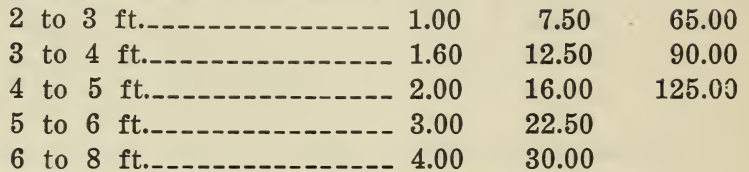

Philadephus coronarius. Sweet Mockorange. 10'

\begin{tabular}{|c|c|c|}
\hline to $3 \mathrm{ft.}$ & .45 & 3.50 \\
\hline to $4 \mathrm{ft}$. & .50 & 4.00 \\
\hline to $5 \mathrm{ft.}$ & .65 & 5.00 \\
\hline 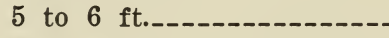 & .75 & 5.50 \\
\hline 6 to $8 \mathrm{ft}$. & 1.00 & 6.50 \\
\hline
\end{tabular}

coronarius aureus. Golden Mockorange. 4'

18 to 24 in.._-_._-_._- $.75 \quad 6.50 \quad 50.00$

coronarius multiflorus plenus. $6^{\prime}$

2 to 3 ft.-_-_-_-_-_-_-- .55 4.50

coronarius speciosissimus. Roundleaf Mockorange. 10'

2 to 3 ft._-_-_-_-_-_-_- $.45 \quad 3.50 \quad 25.00$

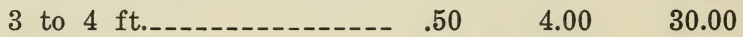

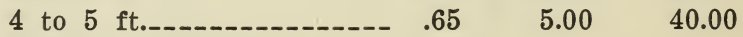

dianthiflorus plenus. 4' 4 ' $50-4.50$

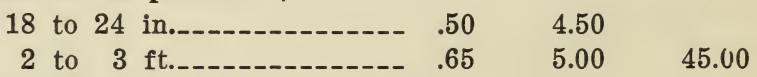

falconeri. Star Mockorange. $8^{\prime}$

\begin{tabular}{|c|c|c|}
\hline 3 to $4 \mathrm{ft}$. & .50 & 4.00 \\
\hline 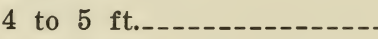 & .65 & 5.00 \\
\hline ft._--_- & .75 & 6.00 \\
\hline to $8 \mathrm{ft.} .-$ & 1.25 & 9.00 \\
\hline
\end{tabular}

gordonianus. Gordon Mockorange. 12'

\begin{tabular}{|c|c|c|c|}
\hline 2 to $3 \mathrm{ft}$. & .45 & 3.50 & 25.00 \\
\hline to $4 \mathrm{ft}$. & .50 & 4.00 & 30.00 \\
\hline to $5 \mathrm{ft}$. & .65 & 5.00 & 40.00 \\
\hline to $6 \mathrm{ft} . \ldots$ & .75 & 5.50 & 45.00 \\
\hline 6 to $8 \mathrm{ft}$. & .85 & 6.00 & 50.00 \\
\hline
\end{tabular}




\section{Philadelphus}

grandiflorus. Big Scentless Mockorange. $8^{\prime}$

\begin{tabular}{|c|c|c|c|}
\hline 2 & $\begin{array}{r}\text { each } \\
.45\end{array}$ & $\begin{array}{r}\text { per } 10 \\
3.50\end{array}$ & $\begin{array}{r}\text { per } 100 \\
25.00\end{array}$ \\
\hline to $4 \mathrm{ft}$. & .50 & 4.00 & 30.00 \\
\hline to $5 \mathrm{ft}$. & .65 & 5.00 & 40.00 \\
\hline to $6 \mathrm{ft}$. & .75 & 5.50 & 45.00 \\
\hline to $8 \mathrm{ft}$ & .85 & 6.00 & 50.00 \\
\hline
\end{tabular}

lemoinei Avalanche. 5'

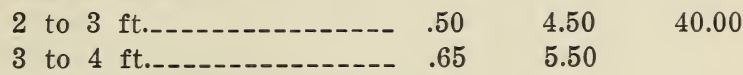

lemoinei Bouquet Blanc. $5^{\prime}$

2 to 3 ft._._-_-_-_-_-_- .65 5.00

lemoinei erectus. $5^{\prime}$

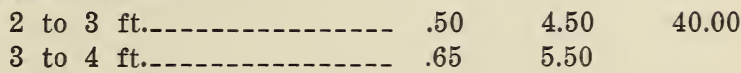

lewisi. Lewis Mockorange. 10'

\begin{tabular}{|c|c|c|}
\hline 2 to $3 \mathrm{ft}$. & .45 & 3.00 \\
\hline ft..-- & .50 & 4.00 \\
\hline 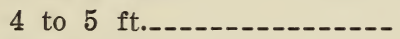 & .65 & 5.00 \\
\hline 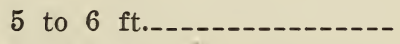 & .75 & 5.50 \\
\hline 6 to $8 \mathrm{ft}$ & .85 & 6.50 \\
\hline
\end{tabular}

nepalensis. Nepal Mockorange. 10'

2 to 3 ft.--_-_-_-_-_-_--- .45

$3.00 \quad 22.00$

3 to 4 ft._-_-_-_-_-_-_- .50

$4.00 \quad 30.00$

4 to 5 ft.-.-_-_-_-_-_- .65

$5.00 \quad 40.00$

5 to $6 \mathrm{ft.}$.

$5.50 \quad 45.00$

6 to $8 \mathrm{ft.}$.

$6.50 \quad 50.00$

nivalis. Snowbank Mockorange. 10'

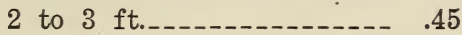

$3.00 \quad 25.00$

3 to $4 \mathrm{ft.}$.

$4.00 \quad 30.00$

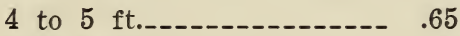

$5.00 \quad 40.00$

5 to $6 \mathrm{ft.}$.

$5.50 \quad 45.00$

6 to $8 \mathrm{ft}$.

$6.50 \quad 50.00$

zeyheri. Zeyher Mockorange. 10'

3 to 4 ft.-_-_-_-_-_-_- .50

$4.00 \quad 30.00$

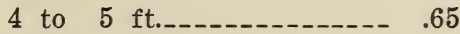

$5.00 \quad 45.00$

5 to 6 ft.-_-_-_-_-_-_-- .75

$6.50 \quad 50.00$

6 to 8 ft.--_-_-_-_-_-_- 1.00

$7.50 \quad 65.00$

8 to $10 \mathrm{ft}$

1.25

virginal. $8^{\prime}$

2 to 3 ft._-_-_-_-_-_ 1.00

3 to $4 \mathrm{ft}$. 
Photinia villosa. $8^{\prime}$

$$
\begin{array}{rr}
\text { each } & \text { per } 10 \\
.75 & 6.50 \\
1.25 & 10.00 \\
1.50 & 12.50
\end{array}
$$

\begin{tabular}{|c|c|}
\hline to $3 \mathrm{ft}$. & .45 \\
\hline to $4 \mathrm{ft}$. & .50 \\
\hline to $5 \mathrm{ft}$. & .60 \\
\hline to $6 \mathrm{ft}$. & .75 \\
\hline to $8 \mathrm{ft}$. & .85 \\
\hline to $8 \mathrm{ft}$. specimens & 3.50 \\
\hline
\end{tabular}$$
3 \text { to } 4 \mathrm{ft}
$$$$
5 \text { to } 6 \mathrm{ft} \text {. }
$$

Physocarpus opulifolius. Ninebark. 10'

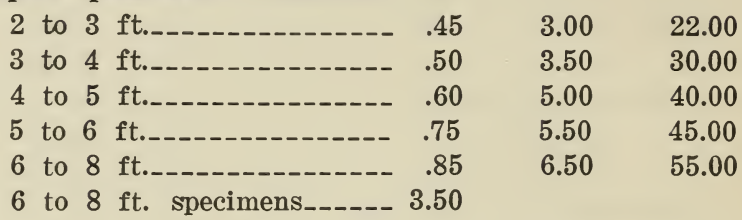

opulifolius aureus. Goldleaf Ninebark. 10'

Potentilla fruticosa. Shrubby Cinquefoil. 4'

$\begin{array}{rrrr}18 \text { to } 24 \text { in.--- } & \\ 2 \text { to } 3 \text { ft.--- } & \end{array}$

Prunus americana. American Plum. 20'

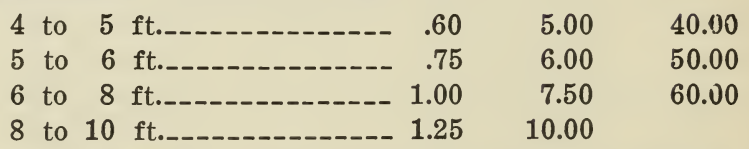

\begin{tabular}{|c|c|c|}
\hline to & ft._-_- & 6.00 \\
\hline to & ft._-n- 1.00 & 7.50 \\
\hline to & ft._-_- & 10.00 \\
\hline to & 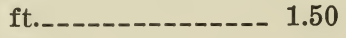 & 12.50 \\
\hline to 10 & -- 1.75 & 15.00 \\
\hline
\end{tabular}

americana Newport. Purple-leaved American Plum. 20' 3 to $4 \mathrm{ft.}$.

besseyi. Bessey Cherry. $8^{\prime}$

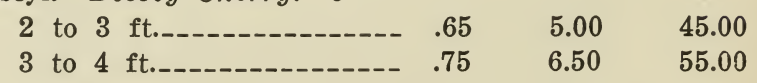

cerasifera pissardi. Purpleleaf Plum. 12'

glandulosa. Flowering Almond. 10'

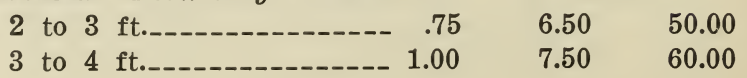




\section{Prunus}

glandulosa sinensis.

Double Pinkflowering Almond. $6^{\prime}$

2 to 3 ft._-_._-ach

per 10

per 100

3 to $4 \mathrm{ft.}$.

5.00

40.00

4 to 5 ft._-_-_-_-_-_-_- 1.25

6.00

50.00

2 to $3 \mathrm{ft}$. own roots_-_._-_ 1.50

10.00

3 to $4 \mathrm{ft}$. own roots

12.50

15.00

\section{glandulosa albiplena.}

Double Whiteflowering Almond. 6'

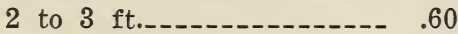

$5.00 \quad 40.00$

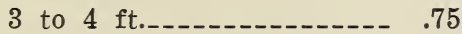

6.00

50.00

4 to 5 ft._-_-_-_-_-_-_- 1.25

10.00

2 to 3 ft. own roots__-_._-_ 1.50

12.50

maacki. Amur Cherry. 12'

5 to 6 ft._._. 6 to 8 ft._-_.

75.00

85.00

martima. Beech Plum. 12'

2 to 3 ft.-_-_-_-_-_-_-_. .65

5.50

50.00

3 to $4 \mathrm{ft.}$.

6.50

55.00

4 to $5 \mathrm{ft}$.

7.50

pennsylvanica. Pin Cherry. 25'

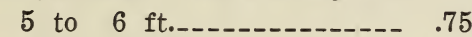

6.00

50.00

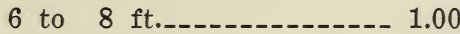

7.50

8 to $10 \mathrm{ft}$.

10.00

60.00

10 to $12 \mathrm{ft}$

spinosa. Blackthorn. 12'

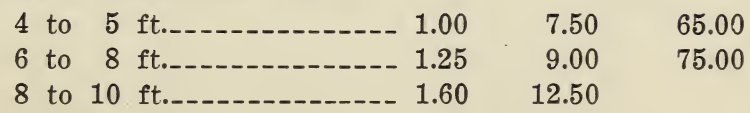

tomentosa. Nanking Cherry. 8'

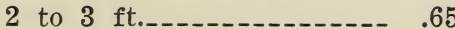

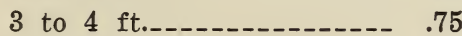

$5.00 \quad 40.00$

4 to $5 \mathrm{ft.}$

$6.50 \quad 50.00$

5 to $6 \mathrm{ft}$

triloba. Doubleflowering Plum. 10'

3 to 4 ft.-_-_-_-_-_-_-_--- 1.25

4 to $5 \mathrm{ft}$. 


\section{Prunus}

\begin{tabular}{|c|c|c|c|}
\hline rginiana. & Chokecherry. $30^{\prime}$ eac & per 10 & \\
\hline 3 to 4 & 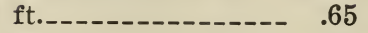 & 5.00 & 45.00 \\
\hline 4 to 5 & ft.--1-- & 6.50 & 50.00 \\
\hline 5 to 6 & ft.-_- 1.00 & 7.50 & $65 . \cup 0$ \\
\hline 6 to $-x-s-1$ & & 10.00 & \\
\hline
\end{tabular}

Pyrus arbutifolia. (See Aronia).

Rhamnus caroliniana. Carolina Buckthorn. 25'

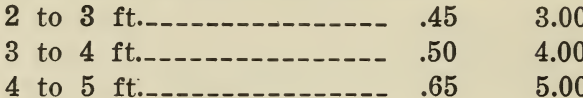

25.00 30.00 45.00

cathartica. Buckthorn. 12'

\begin{tabular}{|c|c|c|c|}
\hline 3 to & ft.--------------- & .45 & 25.00 \\
\hline to & 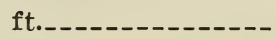 & .55 & 30.00 \\
\hline to & 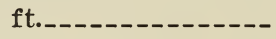 & .65 & 40.00 \\
\hline to 8 & 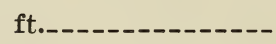 & .90 & 50.00 \\
\hline to 10 & 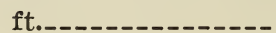 & 1.25 & \\
\hline
\end{tabular}

dahurica. Dahurian Buckthorn. 12'

2 to $3 \mathrm{ft}$.

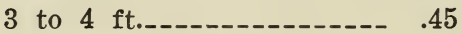

3.50 25.00

4 to $5 \mathrm{ft.}$.

4.50 30.00

5 to $6 \mathrm{ft.} .--$

5.00 40.00

6 to $8 \mathrm{ft}$.

6.50 50.00

frangula. Glossy Buckthorn. 12'

\begin{tabular}{|c|c|c|}
\hline 3 to $4 \mathrm{ft}$. & .45 & 3.50 \\
\hline to $5 \mathrm{ft}$. & .55 & 4.50 \\
\hline to $6 \mathrm{ft}$. & .70 & 5.00 \\
\hline 6 to $8 \mathrm{ft}$ & .90 & 6.50 \\
\hline
\end{tabular}

purshiana. Cascara Buckthorn. 12'

3 to $4 \mathrm{ft.}$.-_-_-_._- .45

4 to $5 \mathrm{ft.}$.

4.00 30.00

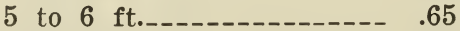

6 to $8 \mathrm{ft}$

6.50 50.00

Rhodotypos kerrioides. Jetbead. $6^{\prime}$

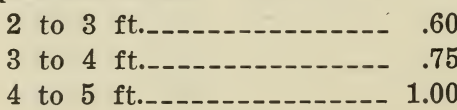

4 to $5 \mathrm{ft}$

Rhus canadensis. Fragrant Sumac. $6^{\prime}$

2 to $3 \mathrm{ft}$.

3 to $4 \mathrm{ft}$. 


\section{Rhus}

copallina. Shining Sumac. 20'

\begin{tabular}{|c|c|c|c|}
\hline 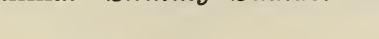 & each & per 10 & per 100 \\
\hline 2 to $3 \mathrm{ft}$. & .50 & 4.50 & 35.00 \\
\hline 3 to $4 \mathrm{ft}$. & .65 & 5.00 & 45.00 \\
\hline to $5 \mathrm{ft}$. & .75 & 6.50 & 50.00 \\
\hline to $6 \mathrm{ft}$. & 1.00 & 7.50 & \\
\hline
\end{tabular}

cotinus. Purple Fringe or Smoketree. 12'

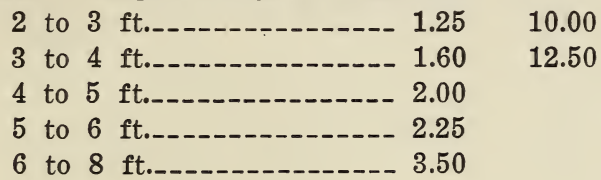

75.00

glabra. Smooth Sumac. 12'

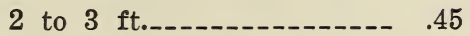

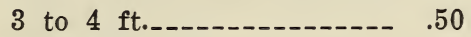

glabra laciniata. Cutleaf Sumac. 5'

2 to $3 \mathrm{ft.}$.

3 to 4 ft.-_-_-_-_-_-_-_- 1.00

javanica. Java Sumac. 18'

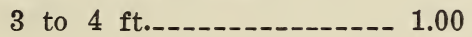

typhina. Staghorn Sumac. 25'

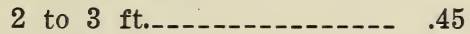

$3.00 \quad 22.00$

3 to $4 \mathrm{ft.}$.

4.00

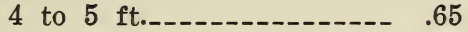

5.00

5 to $6 \mathrm{ft.}$.

5.50

6 to $8 \mathrm{ft.}$.

6.50

30.00

40.00

45.00

55.00

typhina laciniata. Shredded Sumac. 25'

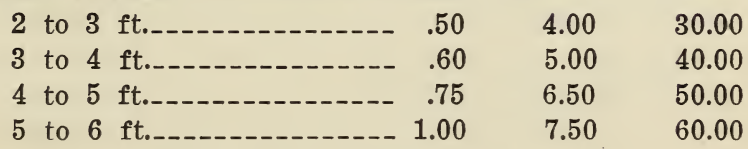

Ribes aureum. Slender Golden Currant. 10'

\begin{tabular}{|c|c|c|}
\hline 2 to $3 \mathrm{ft}$ & .50 & 4.00 \\
\hline to $4 \mathrm{ft}$. & .60 & 4.50 \\
\hline to $5 \mathrm{ft}$. & .65 & 5.50 \\
\hline 5 to $6 \mathrm{ft.}$ & .75 & 7.00 \\
\hline
\end{tabular}

alpinum. Mountain Currant. 4'

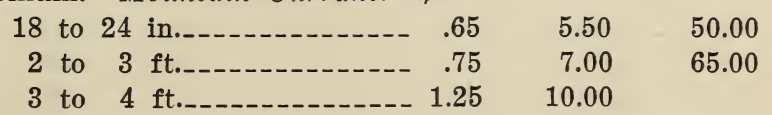




\section{Ribes}

fasciculatum. Winterberry Currant.

$\begin{array}{rrrrr}18 \text { to } 24 \text { in._rer } 10 & \text { per } 100 \\ 2 \text { to } 3 \text { ft._. } & .65 & 5.00 & \\ & .75 & 6.50 & 55.00\end{array}$

gordonianum. Gordon Currant. $8^{\prime}$ 3 to $4 \mathrm{ft.}$

sanguineum. Ruby Winter Currant.

2 to 3 ft._._._. 60

3 to $4 \mathrm{ft}$.

Robinia viscosa. Clammy Locust. 10'

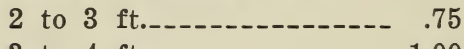

Rosa acicularis. Prickly Rose. 5'

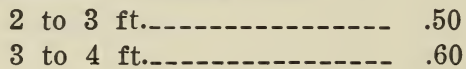

blanda. Meadow Rose. 5'

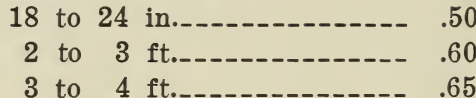

canina. Dogbrier. $8^{\prime}$

$\begin{array}{lllll}2 \text { to } 3 \text { ft._. } & .45 & 4.00 & 30.00 \\ 3 \text { to } 4 \text { ft. } & & \\ 4 \text { to } 5 \text { ft. } & .50 & 4.50 & 40.00 \\ & \end{array}$

foetida. Austrian Copper Rose.

2 to $3 \mathrm{ft}$.

hugonis. Hugonis Rose. ' $6^{\prime}$

2 to $3 \mathrm{ft}$

125.00

humilis. Pasture Rose. 5'

$\begin{array}{rrrrr}18 \text { to } 24 \text { in._. } & \\ 2 \text { to } 3 \text { ft._. } & .50 & 4.00 & 30.00 \\ 3 \text { to } 4 \text { ft. } & .55 & 4.50 & 40.00 \\ & \end{array}$

lucida. Virginia Rose. $6^{\prime}$

18 to 24 in.... 50

2 to 3 ft...............

3 to $4 \mathrm{ft.}$.

multiflora. Japanese Rose.

$\begin{array}{lllll}2 \text { to } 3 \mathrm{ft} . & .50 & 3.50 & 25.00 \\ 3 \text { to } 4 \mathrm{ft} . & .55 & 4.00 & 30.00 \\ 4 \text { to } 5 \mathrm{ft} . & .65 & 5.00 & 40.00\end{array}$


Rosa

nitida. Bristly Rose. 3' each per 10 per 100

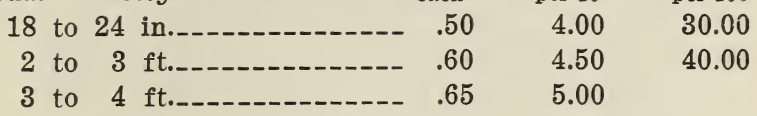

palustris. Swamp Rose. $8^{\prime}$

\begin{tabular}{|c|c|c|c|}
\hline & $24 \mathrm{in}$. & .50 & 4.00 \\
\hline $2 \mathrm{tc}$ & 3 ft... & .55 & 4.50 \\
\hline 3 & 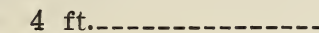 & .60 & 5.00 \\
\hline
\end{tabular}

rubiginosa. Sweetbrier. $6^{\prime}$

\begin{tabular}{|c|c|c|}
\hline 2 to $3 \mathrm{ft}$. & .50 & 4.00 \\
\hline ft..-. & .60 & 4.50 \\
\hline ft. & .65 & 5.00 \\
\hline
\end{tabular}

rubiginosa hybrids. Amy Robsart, Lord Penzance,

Lucy Ashton and Anne of

Geierstein. $6^{\prime}$

2 to $3 \mathrm{ft}$.

rubrifolia. Redleaf Rose. $6^{\prime}$

2 to 3 ft.-_-.--

$5.00 \quad 45.00$

3 to 4 ft..-_-_-_-_-_-_.-. .75

$6.50 \quad 55.00$

4 to $5 \mathrm{ft.}$.

65.00

rugosa. Rugosa Rose. $6^{\prime}$

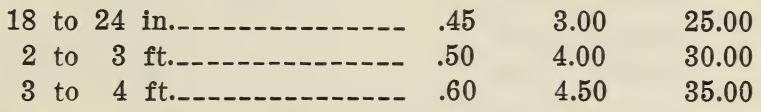

rugosa alba. White Rugosa Rose. $6^{\prime}$

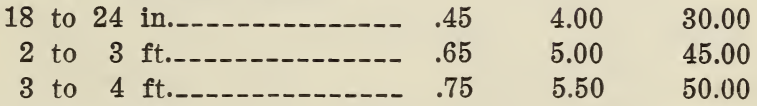

rugosa hybrids.
2 to $3 \mathrm{ft}$.
7.50
3 to $4 \mathrm{ft}$
10.00

Varieties:-Blanche de Coubert, C. F. Meyer C. F. Worth, Agnes Carmen, New Century, Nova Zembla, Mad. Geo. Bruant, Mrs. Anthony Waterer, Belle Poitevine, Sir Thomas Lipton.

setigera. Prairie Rose. $6^{\prime}$

\begin{tabular}{|c|c|c|}
\hline 2 to $3 \mathrm{ft}$. & .45 & 3.00 \\
\hline to $4 \mathrm{ft}$. & .50 & 4.00 \\
\hline ft..-n-n-n- & .60 & 4.50 \\
\hline
\end{tabular}




\section{Rosa}

spinosissima altaica. Altai Rose. 4'

$\begin{array}{rrrrr}18 \text { to } 24 \text { in._-_rer } & \text { each } 10 & \text { per } 100 \\ 2 \text { to } 3 \text { ft._._- } & .60 & 5.00 & 40.00 \\ & & \end{array}$

wichuraiana. Wichurian Rose. 2'

2 year --_-_-

$4.50 \quad 35.00$

3 year -_-

$5.00 \quad 45.00$

4 year -_-_-_-_-_-_-_- $.75 \quad 6.50$

wichuraiana hybrids.

2 year _-_-_-_-_-_-_-_-_ $\quad .75 \quad 6.50$

Jersey Beauty, Sweetheart, Universal Favorite, Manda's Triumph, South Orange Perfection.

\section{Roses}

Hybrid Perpetuals. 2 year No. $1 \quad .90 \quad 6.50$

Alfred Colomb

Anne de Diesbach

Baroness Rothschild

Baron de Bonstettin

Clio

Coq. des Alps

Earl of Dufferin

Eugene Furst

Francois Levet

Gen. Jacqueminot

John Hopper
J. B. Clark

Mrs. John Laing

M. P. Wilder

Magna Charta

Marg. de St. Amande

Margaret Dickson

Paul Neyron

Prince Camille de Rohan

Tom Wood

Ulrich Brunner

Hybrid Teas. 2 year No.

British Queen

Chateau de Clos Vougeot

Etoile de France

Harry Kirk

Jonkheer J. L. Mock

Killarney

Lady Hillingdon

Mrs. McKean
Mad. Abel Chatenay

Mad. Caroline Testout

Marquise De Sinety

Mrs. A. R. Waddell

Ophelia

Pharisaer

Sunburst

White Killarney

American Beauty 1.00

Frau Karl Druschki

Gloire de Chedane-Guinoisseau

Gruss an Teplitz

Mad. Plantier 
Climbing roses.

American Beauty (climbing) - .75

American Pillar _._-_-_-_-_- $\quad .75$

Baltimore Belle -...-_-_-_._. .65

Dr. W. Van Fleet__._._-_.- 1.00

Dorothy Perkins, 2 year_-.- .65

Dorothy Perkins, 3 year_-_._. .75

Excelsa

Gardenia - _._. 1.00

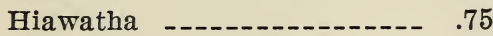

7.50

Paul's Scarlet Climber......- 1.00

Prairie Queen _._._._-_._-_._. .65

7.50

Silver Moon -_-_-_-_-_-_-_ 1.00

White Dorothy Perkins _-_-_ .75

\section{Ramblers:}

\begin{tabular}{|c|c|c|}
\hline Blue & -1-2-1 & .75 \\
\hline Crimson & 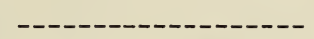 & .75 \\
\hline White - & 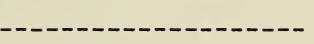 & .75 \\
\hline Yellow & 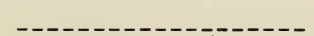 & .75 \\
\hline
\end{tabular}

Baby Rambler _-_-_-_-_- $.90 \quad 7.00$

Erna Teschendorf _-_._-_.- $\quad .90 \quad 7.00$

Ellen Poulsen _-_-_-_-_-_-_ $\quad .90 \quad 7.00$

Persian Yellow -_-_-_-_-_-_-_ $1.00 \quad 7.50$

Rubus deliciosus: Boulder Raspberry. 5'

2 to 3 ft._._._._. 1.00

odoratus. Flowering Raspberry. $6^{\prime}$

2 to 3 ft................... .55

3 to $4 \mathrm{ft.}$

4 to 5 ft._................ .65

pheonicolasius. Wineberry. $8^{\prime}$

2 to 3 ft._._._.

Salix incana. syn. rosmarinifolia.

Rosemary Willow. 20'

$\begin{array}{lrrr}2 \text { to } 3 \mathrm{ft} \text {. shrub form_-_-- } & .45 & 3.00 & 25.00 \\ 3 \text { to } 4 \mathrm{ft} \text {. shrub form_-_-- } & .55 & 4.00 & 30.00 \\ 4 \text { to } 5 \mathrm{ft} \text {. shrub form_-_-- } & .65 & 5.00 & 40.00 \\ 5 \text { to } 6 \mathrm{ft} \text {. shrub form_-_-- } & .75 & 6.00 & \\ 6 \text { to } 8 \mathrm{ft} \text {. shrub form__-_ } 1.25 & 10.00 & \end{array}$


Salix

irrorata. Bluestem Willow. 12'

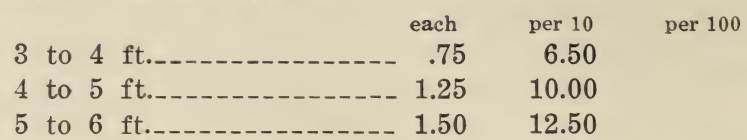

mutabilis. $5^{\prime}$

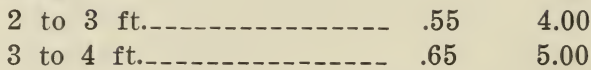

vitellina glauca._-_Blue Russian Willow. 20'

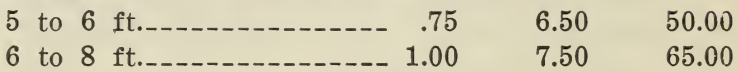

Sambucus canadensis. American Elder. 10'

\begin{tabular}{|c|c|c|}
\hline 2 to $3 \mathrm{ft}$. & .45 & 3.50 \\
\hline 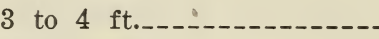 & .50 & 4.00 \\
\hline 5 ft.---- & .65 & 5.00 \\
\hline ft._-n----n & .75 & 6.00 \\
\hline to $8 \mathrm{ft}$. & 1.00 & 7.50 \\
\hline
\end{tabular}

canadensis acutiloba. Cutleaved Elder. 10'

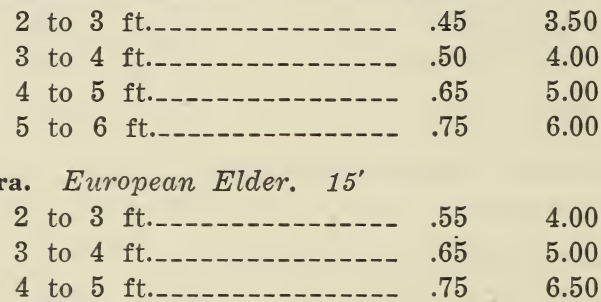

nigra aurea. Golden European Elder. 15'

2 to 3 ft._-_-_-_-_-_--- $.55 \quad 4.00$

30.00

3 to 4 ft._-_-_-_-_-_- $.65 \quad 5.00$

40.09

4 to 5 ft._._.

nigra variegata. Variegated Elder. 10'

3 to 4 ft._-_-_-_-_-_- $.65 \quad 4.50$

4 to 5 ft._._.

racemosa. European Red Elder. 8'

3 to $4 \mathrm{ft.}$.

4 to 5 ft._-_-_-_-_-_-_ 1.00

25.00 30.00 40.00 50.00

5 to 6 ft.-_-_-_-_-_-_-_ 1.25 
Shepherdia argentea. Silver Buffaloberry. 15'

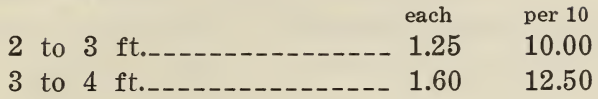

Sophora japonica. Chinese Scholartree. 25'

$$
\begin{aligned}
& 2 \text { to } 3 \text { ft._._._._._._._- } 1.25 \quad 10.00 \\
& 3 \text { to } 4 \text { ft._-_-_-_-_-_-_-_-_ } 1.60 \quad 12.50 \\
& 4 \text { to } 5 \mathrm{ft} \text {. specimens___-_- } 4.50 \\
& 5 \text { to } 6 \mathrm{ft} \text {. specimens____-_ } 5.00 \\
& 6 \text { to } 8 \mathrm{ft} \text {. specimens___._- } 6.50
\end{aligned}
$$

Sorbaria aitchisoni. Kashmir False Spiraea. 8'

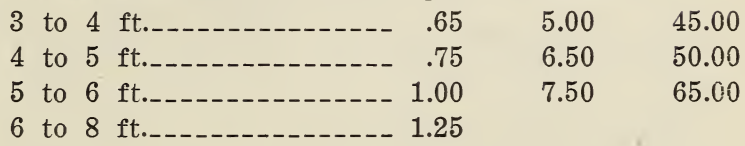

glabrata. $8^{\prime}$

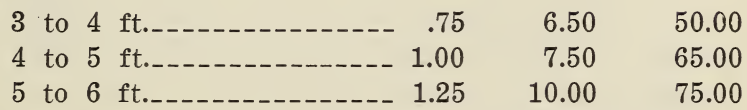

lindleyana. Lindley False Spiraea. 8'

$$
\begin{aligned}
& 2 \text { to } 3 \text { ft._-_._-_-_-_-_. } .55 \quad 4.00 \\
& 3 \text { to } 4 \text { ft._-_-_-_-_-_-_- .65 } 5.00 \\
& 4 \text { to } 5 \text { ft._._-_._._. } .75 \quad 5.50
\end{aligned}
$$

sorbifolia. Ural False Spiraea. 4'

2 to 3 ft.-.- 60

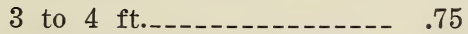

\begin{tabular}{|c|c|c|}
\hline 3 to 4 ft. & .50 & 3.50 \\
\hline to 5 ft. & .65 & 5.00 \\
\hline 5 to $6 \mathrm{ft}$. & .75 & 5.50 \\
\hline
\end{tabular}

4 to 5 ft._._-_-_-_-_-_ 1.00

\begin{tabular}{|c|c|c|c|}
\hline 18 & to 24 in.--- & .50 & 4.00 \\
\hline 24 & in.....- & .65 & 5.00 \\
\hline $2 \frac{1}{2}$ & 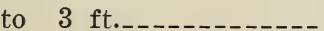 & .75 & 6.00 \\
\hline
\end{tabular}

Spiraea arguta. Garland Spiraea. 6'

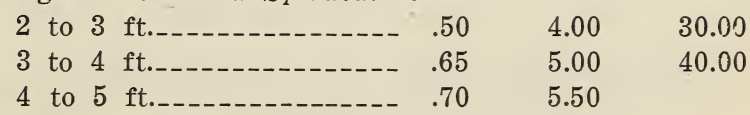

aitchisoni. (See Sorbaria).

billiardi. Billiard Spiraea. $6^{\prime}$

bumalda. Bumalda Spiraea. $3^{\prime}$ 


\section{Spiraea}

bumalda Anthony Waterer.

Anthony Waterer Spiraea. 3' each per 10 per 100 18

24 to 30 in.._-_._-_... .65 .50 30.00 40.00

$21 / 2$ to $3 \mathrm{ft}$

6.50

bumalda walluffi. $\jmath^{\prime}$

$\begin{array}{llll}18 \text { to } 24 \text { in._. } & \\ 24 & \text { to } 30 \text { in._. }\end{array}$

callosa alba. (See japonica ovalifolia).

chamaedryfolia ulmifolia. Elmleaf Spiraea. $6^{\prime}$

2 to $3 \mathrm{ft.}$

douglasi. Douglas Spiraea. $8^{\prime}$

\begin{tabular}{|c|c|c|}
\hline 2 to $3 \mathrm{ft}$ & .45 & 3.00 \\
\hline ft.-_-n- & .50 & 3.50 \\
\hline to $5 \mathrm{ft}$. & .60 & 4.50 \\
\hline
\end{tabular}

fortunei. Fortune Spiraea. 4'

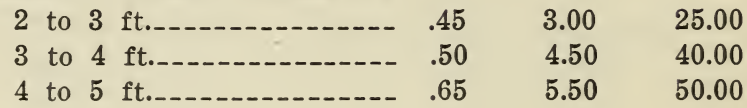

froebeli. Froebel Spiraea. 4'

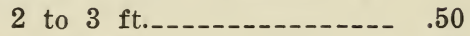

$4.00 \quad 30.00$

3 to 4 ft._.-_- 65

$5.00 \quad 40.00$

japonica ovalifolia. White Papanese Spiraea. 3'

\begin{tabular}{|c|c|c|c|}
\hline & to 24 in.---- & .50 & 4.00 \\
\hline & in.................. & .65 & 5.00 \\
\hline $21 / 2$ & $3 \mathrm{ft}$ & .70 & 5.50 \\
\hline
\end{tabular}

japonica ruberrima. Pink Japanese Spiraea. $5^{\prime}$

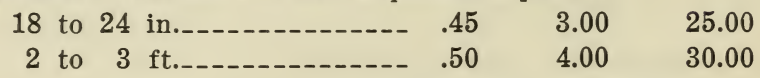

latifolia. Pink Meadow Spirea. 6'

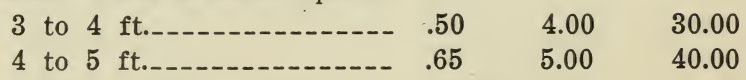

lindleyana. (See Sorbaria).

margaritae. Margarita Spiraea. 5'

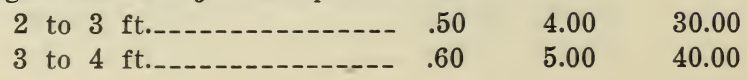




\section{Spiraea}

nipponica rotundifolia. Big Nippon Spiraea. 10'

\begin{tabular}{|c|c|c|c|}
\hline & each & per 10 & per 100 \\
\hline 2 to $3 \mathrm{ft}$ & .50 & 4.00 & 30.00 \\
\hline 3 to $4 \mathrm{ft}$. & .60 & 5.00 & 40.00 \\
\hline 4 to $5 \mathrm{ft}$. & .65 & 5.00 & \\
\hline
\end{tabular}

prunifolia. Bridal Wreath. $8^{\prime}$

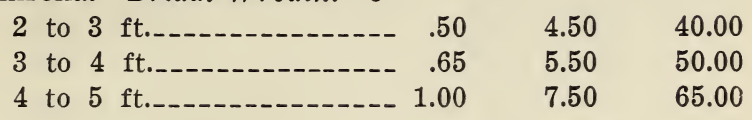

reevesiana. Reeves Spiraea. $8^{\prime}$

\begin{tabular}{|c|c|c|}
\hline 2 to $3 \mathrm{ft}$. & .50 & 4.00 \\
\hline to $4 \mathrm{ft}$. & .60 & 4.50 \\
\hline to $5 \mathrm{ft}$. & .65 & 5.00 \\
\hline to $6 \mathrm{ft}$ & .75 & 6.50 \\
\hline
\end{tabular}

reevesiana fl. pl. Double Reeves Spiraea. $8^{\prime}$

\begin{tabular}{|c|c|c|}
\hline 2 to $3 \mathrm{ft}$. & .50 & 4.00 \\
\hline $4 \mathrm{ft}$. & .65 & 5.00 \\
\hline to $5 \mathrm{ft}$. & .75 & 6.00 \\
\hline
\end{tabular}

salicifolia. Willowleaf Spiraea. 5'

2 to $3 \mathrm{ft.}$

$3.00 \quad 20.00$

3 to $4 \mathrm{ft.} .-\ldots-\ldots$

$3.50 \quad 25.00$

4 to 5 ft._._-_._- .65 $5.00 \quad 40.00$

sorbifolia. (See Sorbaria).

superba. Striped Spiraea. 4'

24 to 30 in............... .65

5.00

syringiflora. Lilac Spiraea. $3^{\prime}$

18 to 24 in.......... .50

35.00

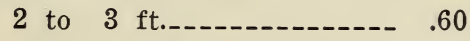

4.50

40.00

thunbergi. Thunberg Spiraea. $5^{\prime}$

18 to 24 in.._._._._._. .45

24 to 30 in.....-...-. .50

3.00

20.00

$21 / 2$ to $3 \mathrm{ft.}$

3.50

25.00

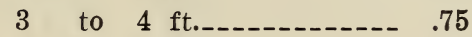

5.00

6.50

40.00

4 to

tomentosa. Hardhack. 4'

\begin{tabular}{|c|c|}
\hline 2 to $3 \mathrm{ft}$. & .50 \\
\hline to $4 \mathrm{ft}$. & .60 \\
\hline
\end{tabular}




\section{Spiraea}

van houttei. Vanhoutte Spiraea. 10'

\begin{tabular}{|c|c|c|c|}
\hline & each & per 10 & per 100 \\
\hline 2 to $3 \mathrm{ft}$. & .45 & 3.00 & 20.00 \\
\hline to $4 \mathrm{ft}$. & .50 & 3.50 & 25.00 \\
\hline to $5 \mathrm{ft}$. & .65 & 5.00 & 40.00 \\
\hline to $6 \mathrm{ft.}$ & .75 & 6.00 & \\
\hline
\end{tabular}

Staphylea bumalda. Bumalda Bladdernut. $8^{\prime}$

$$
\begin{aligned}
& 2 \text { to } 3 \mathrm{ft.} .
\end{aligned}
$$

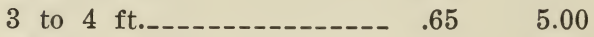

$$
\begin{aligned}
& 4 \text { to } 5 \text { ft._-_-_._- } .75 \quad 6.50
\end{aligned}
$$

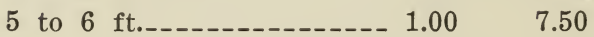

colchica. Colchis Bladdernut. 12'

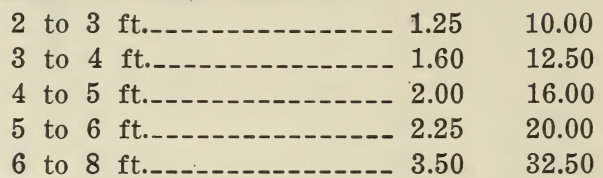

pinnata. European Bladdernut. 12'

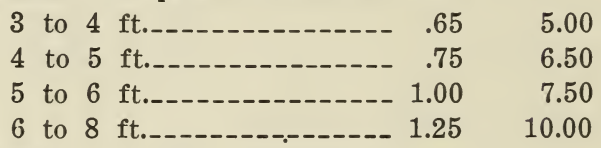

trifolia. American Bladdernut. 12'

$$
\begin{aligned}
& 2 \text { to } 3 \text { ft.-_-_-_-_-_-_- } .50 \quad 4.50
\end{aligned}
$$

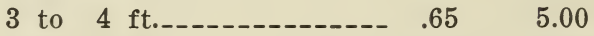

$$
\begin{aligned}
& 4 \text { to } 5 \text { ft._-_-_-_-_-_- } .75 \quad 6.50 \\
& 5 \text { to } 6 \mathrm{ft.} \text {.-_-_-_-_-_--- } 1.00 \quad 7.50 \\
& 6 \text { to } 8 \text { ft._-_-_-_-_-_-_-_ } 1.25 \quad 10.00 \\
& 8 \text { to } 10 \mathrm{ft.} \text {._._._._-_ } 1.60 \quad 12.50
\end{aligned}
$$

\begin{tabular}{|c|c|}
\hline to $3 \mathrm{ft}$. & .50 \\
\hline 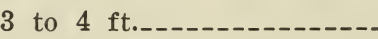 & .65 \\
\hline to $5 \mathrm{ft}$. & .75 \\
\hline
\end{tabular}

Stephanandra flexuosa. Cutleaf Stephanandra. 6'

Stewartia pentagyna. Mountain Stewartia. 15'

$$
\begin{aligned}
& 2 \text { to } 3 \mathrm{ft} . \\
& 3 \text { to } 4 \text { ft.-_-_-_-_-_-_-_- } 3.25 \\
& 4 \text { to } 5 \mathrm{ft.} . \\
& 5 \text { to } 6 \mathrm{ft.} \text {._-_-_.- } 6.50
\end{aligned}
$$

Styrax japonica. Japanese Snowbell. 20'

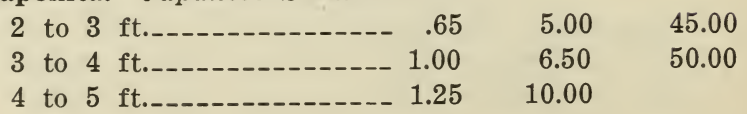


Symphoricarpus mollis. Spreading Snowberry. 6'

$\begin{array}{rrrrr}2 & \text { each } & \text { per } 10 & \text { per } 100 \\ 3 \text { to } 3 \text { ft._. } 4 \text { ft._-_._- } & .45 & 3.50 & 25.00 \\ & & .60 & 4.50 & 35.00\end{array}$

racemosus. Snowberry. $6^{\prime}$

\begin{tabular}{|c|c|c|}
\hline 2 to $3 \mathrm{ft}$. & .45 & 3.50 \\
\hline $4 \mathrm{ft.}$. & .60 & 4.50 \\
\hline 5 ft._- & .75 & 6.50 \\
\hline 5 to $6 \mathrm{ft.}$ & 1.00 & 7.50 \\
\hline
\end{tabular}

vulgaris. Coralberry. $5^{\prime}$

\begin{tabular}{|c|c|c|}
\hline 2 to 3 ft..- & .45 & 3.00 \\
\hline to $4 \mathrm{ft}$. & .50 & 3.50 \\
\hline ft._-_-_-_--_-_--- & .65 & 5.00 \\
\hline
\end{tabular}

Symplocos paniculata. syn. crataegoides.

Asiatic Sweetleaf. 10'

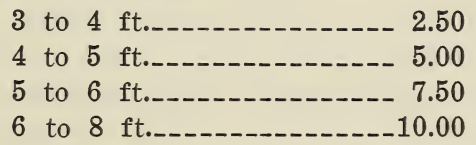

Syringa chinensis. syn. rothomagensis.

Chinese Lilac. 10'

\begin{tabular}{|c|c|c|}
\hline 2 to $3 \mathrm{ft}$. & .60 & 4.50 \\
\hline 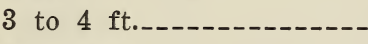 & .75 & 5.50 \\
\hline ft._. & 1.00 & 7.50 \\
\hline
\end{tabular}

chinensis saugeana. Purple Chinese Lilac. 10'

\begin{tabular}{|c|c|c|}
\hline 2 to $3 \mathrm{ft}$. & .60 & 4.50 \\
\hline 4 ft.ı-n-s- & .75 & 5.50 \\
\hline to $5 \mathrm{ft}$. & 1.00 & 7.50 \\
\hline
\end{tabular}

emodi. Himalayan Lilac. $8^{\prime}$

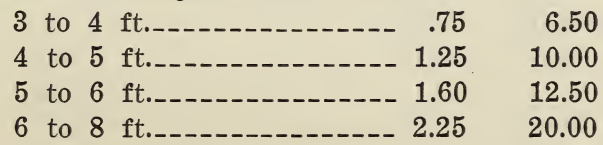

japonica. Japanese Tree Lilac. 20'

\begin{tabular}{|c|c|c|}
\hline 3 to & ft._-_-_-n & 10.00 \\
\hline to & ft._-n- 1.60 & 12.50 \\
\hline to & ft._-_-_- 2.00 & 16.00 \\
\hline to 8 & ft._-_-n- 3.25 & 25.00 \\
\hline 8 to 10 & ft._-_- 4.00 & 30.00 \\
\hline
\end{tabular}




\section{Syringa}

josikaea. Hungarian Lilac. 10'

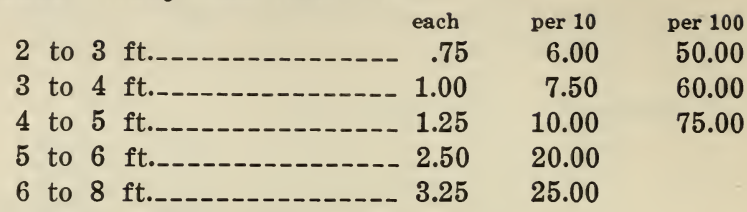

pekinensis. Peking Lilac. $15^{\prime}$

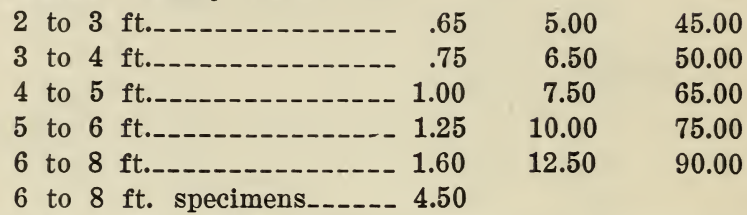

persica. Persian Lilac. 10'

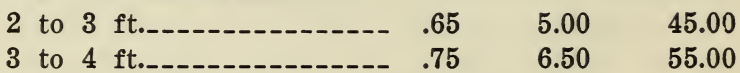

persica alba. White Persian Lilac. 10'

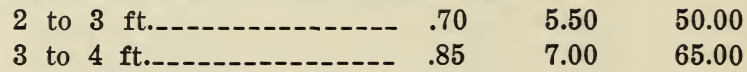
villosa. Late Lilac. $8^{\prime}$

2 to 3 ft.-_-_-_-_-_- $.60 \quad 5.00$

3 to $4 \mathrm{ft.}$._-_-_._- $1.00 \quad 7.00$

40.00

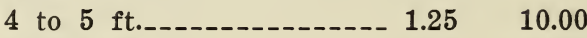
55.00

5 to 6 ft._._-_._- $2.50 \quad 20.00$

vulgaris. Common Purple Lilac. 15'

2 to $3 \mathrm{ft.}$.

$4.00 \quad 30.00$

3 to 4 ft._._._._.

5.00

40.00

4 to $5 \mathrm{ft}$._-_-_-_._- $.75 \quad 6.50$

5 to $6 \mathrm{ft.}$

4 to $5 \mathrm{ft}$. clumps_._-_.-_ 4.00

5 to $6 \mathrm{ft}$. clumps__-_._-- 5.00

vulgaris alba. Common White Lilac. 15'

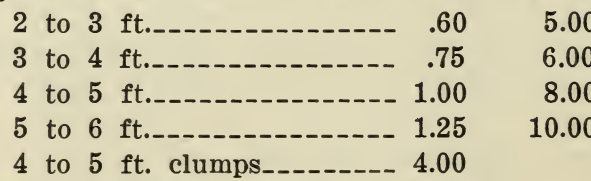

vulgaris. Named Varieties.

\begin{tabular}{|c|c|}
\hline 2 to $3 \mathrm{ft.}$ & 8.00 \\
\hline 3 to $4 \mathrm{ft}$. & 11.00 \\
\hline $5 \mathrm{ft}$. & \\
\hline
\end{tabular}


Syringa

Belle de Nancy-Double Rose.

2-3' 3-4' 4-5'

Chas. Joly-Dark Purplish Red.

$2-3^{\prime} \quad 3-4^{\prime}$

La Tour d'Auvergne-Double Purple.

$2-3^{\prime} \quad 3-4^{\prime} \quad 4-5^{\prime}$

Ludwig Spaeth-Single Red.

$2-3^{\prime} \quad 3-4^{\prime} \quad 4-5^{\prime}$

Mad. Abel Chatenay-Double White.

2-3' 3-4' 4-5'

Mad. Casimer Perier-Double Creamy White.

$2-3^{\prime} \quad 3-4^{\prime} \quad 4-5^{\prime}$

Mad. Lemoine-Large Double White.

$2-3^{\prime} \quad 3-4^{\prime} \quad 4-5^{\prime}$

Marie Le Graye-Single White.

$2-3^{\prime} \quad 3-4^{\prime}$

Pres. Grevy-Double Blue.

2-3' 3-4' 4-5' 5-6'

Princess Alexandra-Single White.

$2-3^{\prime} \quad 3-4^{\prime} \quad 4-5^{\prime}$

We have a limited quantity of the newer varieties of Lemoine's hybrid named lilacs, which we offer as follows. A list of varieties will be forwarded on request.

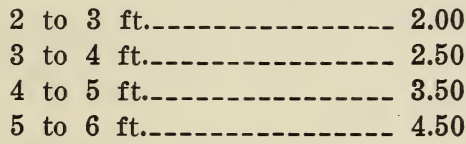

Tamarix africana. African Tamarix. 15'

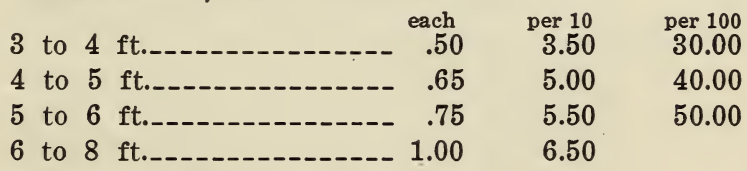

gallica. French Tamarix. 10'

\begin{tabular}{|c|c|c|}
\hline to $4 \mathrm{ft}$. & .50 & 3.50 \\
\hline 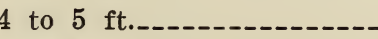 & .65 & 5.00 \\
\hline to $6 \mathrm{ft}$. & .75 & 5.50 \\
\hline
\end{tabular}

gallica indica. India Tamarix. 10'

3 to $4 \mathrm{ft.}$.

$3.50 \quad 30.00$

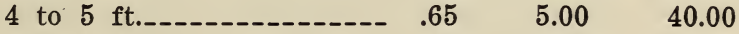

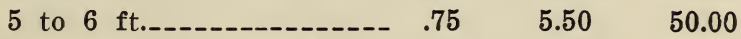

6 to 8 ft._-_-_-_-_.-_ $1.00 \quad 6.50 \quad 55.00$ 
Tamarix.

odessana. Odessa Tamarix. $6^{\prime}$

\begin{tabular}{|c|c|c|c|}
\hline & each & per 10 & per 100 \\
\hline 3 to $4 \mathrm{ft.}$ & .50 & 3.50 & 30.00 \\
\hline 4 to $5 \mathrm{ft}$. & .65 & 5.00 & 40.00 \\
\hline to $6 \mathrm{ft}$. & .75 & 5.50 & 50.00 \\
\hline
\end{tabular}

pentandra. Fivestamen Tamarix. 12'

3 to $4 \mathrm{ft.}$.

tetandra purpurea. Fourstamen Tamarix. 10'

3 to 4 ft._-_-___-___- $.75 \quad 5.00$

Vaccinium corymbosum. Highbush Blueberry.

2 to 3 ft.________B. \& B. $3.00 \quad 25.00$

Viburnum acerfolium. Mapleleaf Viburnum. $5^{\prime}$

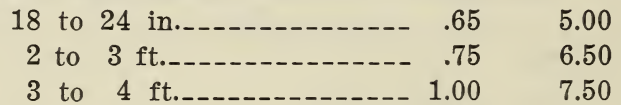

alnifolium. Hobblebush. 15'

2 to 3 ft.-_-_-_-_-_- .55 $4.00 \quad 30.00$

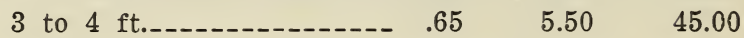

americanum. American Cranberrybush. 10'

2 to 3 ft._-_-_._- $\quad .60 \quad 5.00$

45.00

3 to $4 \mathrm{ft.}$

carlesi. Fragrant Viburnum. 4'

18 to 24 in._-_-_-_B. \& B. $3.00 \quad 25.00$

2 to 3 ft._-_-_-_-_B. \& B. $3.50 \quad 30.00$

cassinoides. Withe Rod. $6^{\prime}$

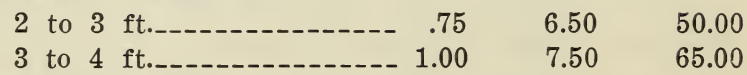

dentatum. Arrowwood. 12'

2 to 3 ft._-_-_-_-_- $.50 \quad 4.00 \quad 30.00$

3 to $4 \mathrm{ft.}$.-_-_- $\quad .60 \quad 5.00 \quad 40.00$

4 to 5 ft.-_-_-_-_-_- $\quad .75 \quad 6.00 \quad 50.00$

5 to 6 ft.-_-_-_-_-_-_-_ $1.00 \quad 7.50 \quad 65.00$

dilatatum. Linden Viburnum. 10'

2 to 3 ft._._-_-_-_-_._- $1.25 \quad 10.00$

3 to 4 ft.-_-_-_-_-_------ $1.60 \quad 12.50$

lantana. Wayfaring Tree. 15

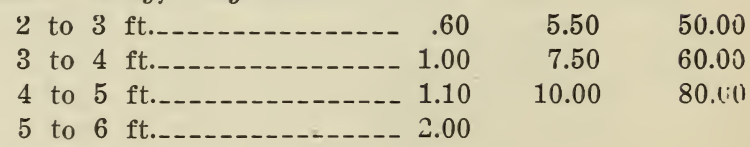




\section{Viburnum}

lentago. Nannyberry. 20'

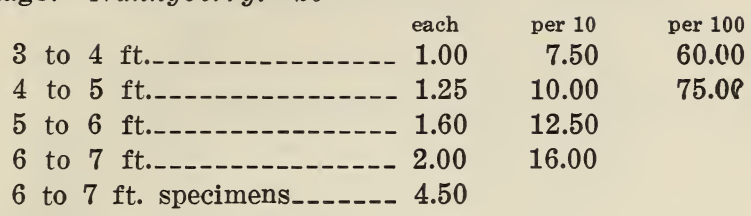

molle. Kentucky Viburnum. 10'

\begin{tabular}{|c|c|c|}
\hline 2 to $3 \mathrm{ft}$. & .50 & 4.00 \\
\hline 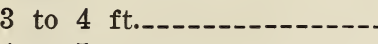 & .60 & 5.00 \\
\hline 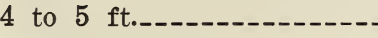 & .75 & 6.00 \\
\hline 5 to 6 ft.-- & 1.00 & 7.50 \\
\hline
\end{tabular}

nudum. Smooth Withe Rod. 8'

$$
\begin{aligned}
& 2 \text { to } 3 \text { ft._-_-_-_-_-_ } 1.00 \quad 7.50
\end{aligned}
$$

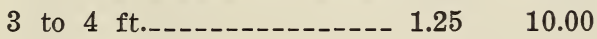

$$
\begin{aligned}
& 4 \text { to } 5 \mathrm{ft} .
\end{aligned}
$$

opulus. High Bush Cranberry. 10'

$$
\begin{aligned}
& 2 \text { to } 3 \text { ft._-_-_-_-_-_-_-_ } .75 \\
& 3 \text { to } 4 \text { ft._._-_-_-_-_._- .85 }
\end{aligned}
$$

$9.00 \quad 80.00$

opulus nanum. Dwarf Cranberry bush. 2'

$$
10 \text { to } 12 \text { in.-_o } 15 \text { in.-_-_-_- } 12 \text { - }
$$

opulus sterile. Common Snowball. 10'

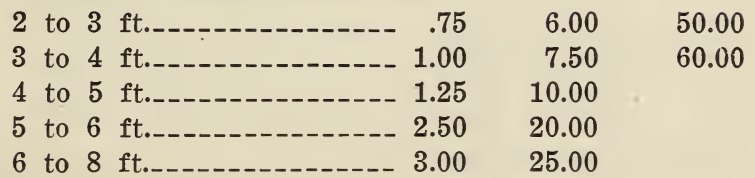

prunifolium. Blackhaw. 12'

$$
3 \text { to } 4 \text { ft.-_- } 5 \text { to } 5 \text { ft._-_- } 1.60 \quad 12.50
$$

pubescens. Downy Viburnum. $6^{\prime}$

$$
2 \text { to } 3 \text { ft.-_-_- } 3 \text { to } 4 \text { ft._-_- } 1.00
$$

rhytidophyllum. Leatherleaf Viburnum. $8^{\prime}$

18 to 24 in.-_-_-_B. \& B. $3.25 \quad 25.00$

2 to 3 ft._-_-_-_B. \& B. $4.00 \quad 32.50$ 


\section{Viburnum}

rufidulum. Southern Blackhaw. 10'

2 to $3 \mathrm{ft.} \quad \begin{array}{lll}\text { each } & \text { per } 10 & \text { per } 100\end{array}$

sargenti. Sargent Cranberrybush. 10'

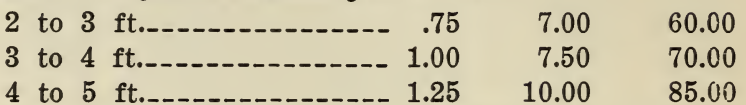

sieboldi. Siebold Viburnum. 10'

$$
\begin{aligned}
& 3 \text { to } 4 \mathrm{ft} .-[-\ldots-0 .-100 \\
& 4 \text { to } 5 \text { ft._-_-_-_._-_._- } 1.60 \quad 12.50 \\
& 5 \text { to } 6 \text { ft._-_._- } 2.25 \quad 20.00 \\
& 6 \text { to } 8 \mathrm{ft} \text {._._. } 25.00
\end{aligned}
$$

tomentosum. Doublefile Viburnum. $8^{\prime}$

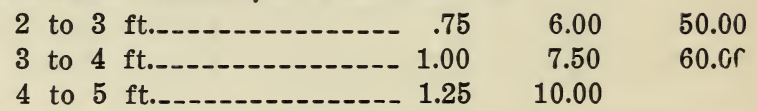

tomentosum plicatum. Japanese Snowball. $8^{\prime}$

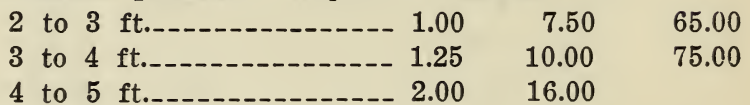

wrighti. Wright Viburnum. $8^{\prime}$
2 to $3 \mathrm{ft.}$.
3 to $4 \mathrm{ft.}$.

Vitex agnus castus. Chaste-tree. 4'
2 to 3 ft..-.-.--
$3.50 \quad 25.00$
3 to $4 \mathrm{ft.}$._._._. $.55 \quad 4.00 \quad 30.00$

agnus castus alba. White Chaste-tree. 4'

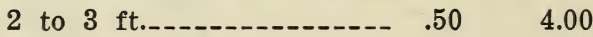
3 to 4 ft..-_-_-_-_-_- $.60 \quad 4.50$

Weigela Abel Carriere. 10'

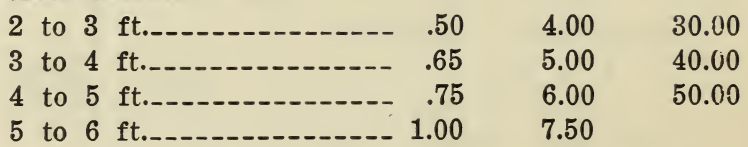

amabilis. Rose Weigela. $8^{\prime}$

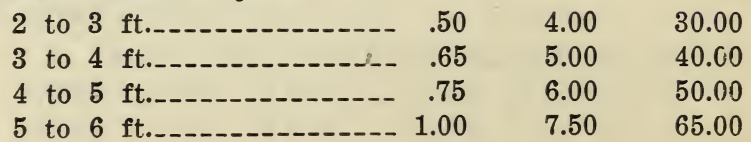




\section{Weigela}

candida. Snow Weigela. $8^{\prime}$

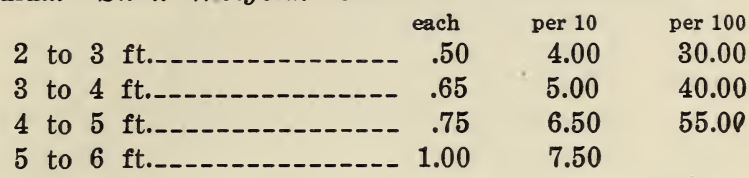

desboisi. Desbois Weigela. $8^{\prime}$

2 to $3 \mathrm{ft.}$

$4.50 \quad 30.00$

3 to $4 \mathrm{ft.}$.

$5.00 \quad 40.10$

4 to 5 ft._._-_-_._- .75

$6.50 \quad 55.00$

5 to $6 \mathrm{ft.}$

Eva Rathke. 5'

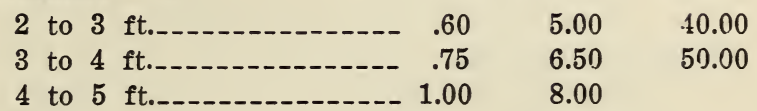

floribunda. Crimson Weigela. $8^{\prime}$

2 to $3 \mathrm{ft.}$

$5.00 \quad 40.00$

3 to $4 \mathrm{ft.}$

$6.50 \quad 50.00$

Gustav Mallot. $8^{\prime}$

\begin{tabular}{|c|c|c|}
\hline to $3 \mathrm{ft}$. & .55 & 4.50 \\
\hline to $4 \mathrm{ft}$. & .65 & 5.00 \\
\hline to $5 \mathrm{ft}$. & .75 & 6.50 \\
\hline to $6 \mathrm{ft}$. & 1.00 & 7.50 \\
\hline to $8 \mathrm{ft}$. heary & 1.60 & 12.50 \\
\hline
\end{tabular}

hortensis rubra. $8^{\prime}$

\begin{tabular}{|c|c|c|c|}
\hline to $3 \mathrm{ft}$. & .55 & 4.50 & 32.00 \\
\hline ft...-. & .65 & 5.00 & 40.00 \\
\hline 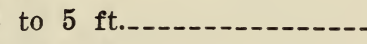 & .75 & 6.50 & 50.00 \\
\hline to $6 \mathrm{ft}$. & 1.00 & 7.50 & 65.00 \\
\hline
\end{tabular}

rosea. Pink Weigela. $8^{\prime}$

2 to $3 \mathrm{ft.}$.

$4.00 \quad 30.00$

3 to 4 ft._-_-_-_-_-_-_. .65

$5.00 \quad 40.00$

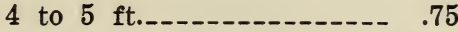

$6.50 \quad 50.00$

5 to $6 \mathrm{ft}$.......... $1.00 \quad 7.50$

rosea nana variegata. Dwarf Variegated Weigela. $5^{\prime}$

\begin{tabular}{|c|c|c|}
\hline to $3 \mathrm{ft}$. & .55 & 4.50 \\
\hline ft.-_- & .65 & 5.50 \\
\hline to $5 \mathrm{ft}$. & 1.00 & 7.50 \\
\hline
\end{tabular}


Weigela

sieboldi argenteomarginata.

Variegated Weigela. 8'

3 to $4 \mathrm{ft}$.

each

per 10

per 100

4 to 5 ft.-._.

5.00

5 to $6 \mathrm{ft}$.

6.50

6 to $8 \mathrm{ft}$.

Vanhoutte. Van Houtte Weigela. $8^{\prime}$

2 to 3 ft._-_._-_-_-_-_. .55

3 to 4 ft.-_-_-_-_-

4 to $5 \mathrm{ft}$

.75

6.50 50.00

Xanthoceras sorbifolia. $10^{\prime}$

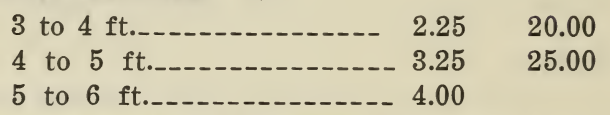

Zanthorhiza apiifolia. Yellowroot. $3^{\prime}$

12 to 15 in. clumps_._._. .45

15 to 18 in. clumps_._._. .50

18 to 24 in. clumps__._-_. .65

Zanthoxylum americanum. Prickly Ash. 15'

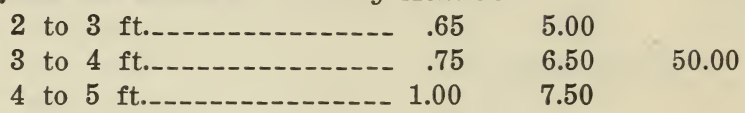

\section{Vines}

Actinidia arguta. Bower Actinidia.
2 year
.75
6.00
50.00

polygama. Silver Vine.

2 year 1.00

Akebia quinata. Fiveleaf Akebia.

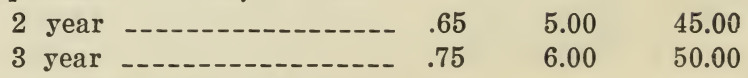

Ampelopsis aconitifolia. Monkshood Vine.

$\begin{array}{lllll}2 & \text { year }-1.50 & & \\ 3 & \text { jear } \\ \end{array}$

heterophylla. Porcelain Ampelopsis.

\begin{tabular}{|c|c|c|c|}
\hline 2 year & .40 & 3.00 & 20.00 \\
\hline year & - & 3.50 & 25.00 \\
\hline year & 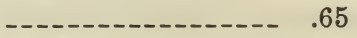 & 5.00 & 40.00 \\
\hline re & ariegata & & \\
\hline year & 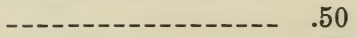 & 4.00 & 30.00 \\
\hline year & 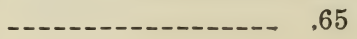 & 5.00 & \\
\hline
\end{tabular}


Ampelopsis

quinquefolia. Virginia Creeper.

$\begin{array}{rrrrr}2 & \text { year } & \text { each } & \text { per } 10 & \text { per } 100 \\ 3 \text { year } & .40 & 3.00 & 20.00 \\ & & .45 & 3.50 & 25.00\end{array}$

quinquefolia engelmanni. Englemann Creeper.

$\begin{array}{lllll}2 & \text { year } \\ 3 & \text { year } & & & \\ 4 & & & \\ 4 & \text { year }\end{array}$

quinquefolia saintpauli. St. Paul Creeper.

2 year _. 6.50

tricuspidata syn. veitchi. Boston Ivy.

$\begin{array}{lllll}2 \text { year } & & & \\ 3 \text { year } & 65 & 500 & 40.00 \\ & & \end{array}$

tricuspidata lowi. Geranium Ivy.

2 rear, from pots _._. $1.10 \quad 10.00 \quad 80.00$

Aristolochia sipho. Dutchman's Pipe.

2 jear

Bignonia grandiflora. Chinese Trumpetcreeper.

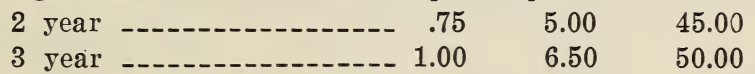

radicans. Trumpetcreeper.

2 year

3 year

speciosa rubra. Painted Trumpetcreeper.

$\begin{array}{llr}2 & \text { year } \\ 3 & \text { year } & \end{array}$

Celastrus articulatus. Japanese Bittersweet.

$\begin{array}{lllll}2 & \text { year } \\ 3 & \text { jear } \\ 4 & \text { year }\end{array}$

scandens. Native Bittersweet.

2 year

3 jear

Clematis apiifolia. October Clematis.

2 year -

coccinea. (See texensis).

hybrids. Large Flowering Clematis.

2 year -..-_ 10.100

Jackmanni, Mad. Ed. Andre, Henryi,

Duchess of Edinburg.

orientalis. Oriental Clematis.

2 year .50 


\section{Clematis}

paniculata. Sweet Autumn Clematis.

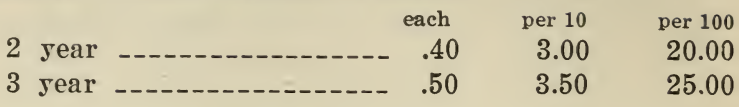

tangutica. Golden Clematis.

2 year --1.-- $75 \quad 5.00$ 45.00

texensis syn. coccinea. Scarlet Clematis.

2 year _-_-_-_-_-_._- $65 \quad 5.00$

virginiana. Virgins-bower.

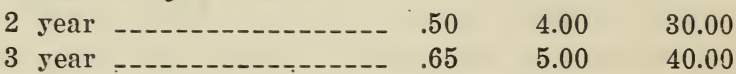

Hedera helix. English Ivy.

2 year, 4 in. pots___._-_ $\quad .60$. $5.00 \quad 40.00$

3 year, 4 in. pots_-__-_-_- $1.00 \quad 7.50 \quad 50.00$

helix gracilis. Small-leaved English Ivy.

2 year, 3 in. pots__._._._. $.60 \quad 5.00$

3 vear, 3 in. pots____-_-_ $1.00 \quad 7.50 \quad 50.00$

Lonicera caprifolium. Sweet Honeysuckle.

$\begin{array}{lllll}2 & \text { year } & & \\ 3 & \text { year } \\ \end{array}$

browni plantieriensis. Orange Honeysuckle.

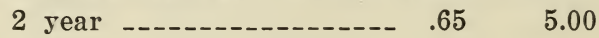

heckrotti. Everblooming Honeysuckle.

2 year -

35.00

henryi. Honeysuckle.

2 year _-_. $1.00 \quad 7.50 \quad 60.00$

hirsuta. Hoary Honeysuckle.

2 year _._._. $1.00 \quad 7.50$

japonica. Japanese Honeysuckle.

$\begin{array}{lllll}2 & \text { year }-1 .-15 & 3.00 & 20.00 \\ 3 \text { year -- } & & \end{array}$

japonica halleana. Hall Japanese Honeysuckle.

2 sear --_-_-_-_-_- $\quad .45 \quad 3.00 \quad 20.00$

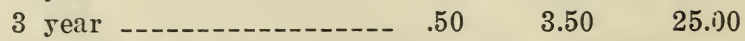

japonica reticulata aurea.

Yellow Japanese Honeysuckle.

2 year --_-_-_-_-_-_-_.- $.45 \quad 3.50 \quad 25.00$

periclymenum belgica. Dutch Woodbine.

$\begin{array}{lllll}2 \text { year }-1.00 & 4.00 & 30.00 \\ 3 \text { year }-1.00 & \end{array}$ 


\section{Lonicera}

prolifera syn. sullivanti. Grape Honeysuckle. each per 10

3 year --_-_-_-_- $.65 \quad 5.50$

per 100

sempervirens. Trumpet Honeysuckle.

2 year - -

verna.

2 year -

Lycium. (See Shrubs).

Periploca graeca. Silk Vine.

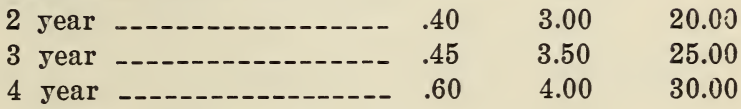

Polygonum auberti. China Fleecevine.

2 year -_-_._. $1.00 \quad 7.50$

65.00

baldschuanicum. Silver Fleecevine.

2 year -_-_-_-_.- $1.00 \quad 7.50$

Pueraria thunbergiana. Kudzu-bean.

2 year -_-_-_-_._.-. 3500

20.00

Schizophragma hydrangeoides.

Japanese Hydrangea-vine.

from pots -_. 10.00

Solanum dulcamara. True Bittersweet.

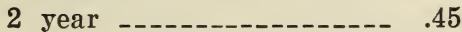

$3.00 \quad 20.00$

Tecoma. (See Bignonia).

Vinca minor. Periwinkle.

8 to 12 in._-_._. $20 \quad 1.50 \quad 10.00$

minor alba. White Periwinkle.

2 year -------------- $\quad .50 \quad 4.00 \quad 35.00$

minor rubra plena. $D b l$. Red Periwinkle.

2 year -

Vitis aestivalis. Summer Grape.

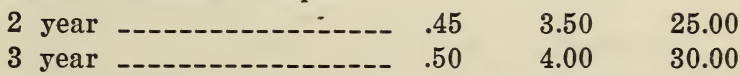

coignetiae. Gloryvine.

2 year -

cordifolia. Frost or Winter Grape.

2 year -

$3.50 \quad 25.00$

3 year -_-_-_-_-_-_-_ $\quad .50 \quad 4.00 \quad 30.00$ 
Vitis

labrusea. Fox Grape.

2 year each

per 10

per 100

3 year

.45

3.50

25.00

vulpina. Riverbank Grape.

2 year

.50

4.00

35.00

3 jea

Wistaria frutescens. American Wistaria.
2 year
4.00
30.00
3 year
5.00
40.00

frutescens magnifica. Yelloweye Wistaria.

$\begin{array}{llll}2 & \text { year } \\ 3 \text { year } \\ \end{array}$

multijuga. Japanese Wistaria.

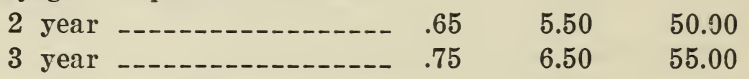

sinensis. Chinese Purple Wistaria.

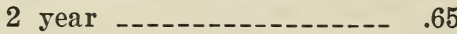

$5.50 \quad 50.110$

3 year -........... .75

$7.00 \quad 65.00$

3 to $4 \mathrm{ft}$. standard______- $1.60 \quad 12.50$

4 to $5 \mathrm{ft}$. standard____-_- $2.50 \quad 20.00$

sinensis alba. Chinese White Wistaria.

$\begin{array}{llrrr}2 & \text { year } & & & \end{array}$

\section{Hardy Perennials}

Young transplanted, field grown stock

Acanthus mollis. Purple Rose, July, $4^{\prime}$..-- $\$ 2.50$ mollis latifolius. Rose, July, 2-3' _-.- 2.50 Achillea ageratum. Yellow, July, 1'_...- 1.50 12.00 filipendulina. Yellow, June, July, 3'_- $1.50 \quad 12.00$ millefolium Cerise Queen. Rose, July, 2' -......... 1.50

ptarmica fl. pl. White, July, 2'---_- 1.50 12.00 ptarmica Boule de Neige. White, June, July, 2' _-_........ $1.50 \quad 12.00$ ptarmica Perry White. June, July, 2' --- $1.50 \quad 12.00$ tomentosa. Yellow, June, $1^{\prime}$ _-_-_-_- $1.50 \quad 12.00$ 
Aconitum autumnale. Blue, July, August, 4' 3.00

fischeri. Blue, September, 3' -.-.-- 3.00 napellus. Light blue, July, Aug., 4'_- 3.00 lycoctonum. Yellow, June, July, 3'_-- 6.00 50.00 Spark's variety. Violet blue, July, Aug. 5'

Actaea alba. White, May, June, 3-4' -.-- 1.50 rubra. Red, May, June, 3-4'_......- 1.50

Aegopodium podagraria variegatum.

Variegated foliage, 1'_-_-_-_-_-_ 1.50

Agrostemma. (See Lychnis).

Ajuga genevensis. Bright blue, May, 6" $6_{--} 1.50$

reptans. Blue, May, 6" _..._._._._ 1.50

Althea rosea. Hollyhock.

Double. Separate colors, July, Aug., 5' 1.50

Double. Chater's strain, separate colors 2.20

Fringed Allegheny. July, August, 5'-- 1.50

12.00

Single. Mixed colors, July, Aug., 5'_-- 1.50

Alyssum argenteum. Yellow, July, Aug., 6"

saxatile compactum. Yellow, May 1'--

saxatile sulphureum. Yellow, May, 1'_ 2.50

Amsonia tabernaemontana. Blue,

May, June, 3'

Anchusa capensis. Blue, all summer, 11/2' -italica. Blue, June, 4' _-_-_-_-_-- 1.50 italica Dropmorei. Blue, June, 4-5' -myosotidiflora. Bright blue, May, 1'--

Anemone hupehensis. Mauve, Aug., Sept. 1' japonica alba. White, Fall, 3' japonica Geante des Blanches.

White, Fall, 3' japonica Lady Ardilaun.

White, Fall, 4' japonica Prince Heinrich.

Deep pink, Fall, 3' japonica Queen Charlotte.

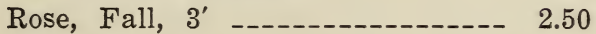

Less than five at double the rate per hundred. 


\section{Anemone}

japonica Rose d'Autumn.

$\begin{array}{crr}\text { Pink, Fall, 3' } & \text { per 10 } & \text { per } 100 \\ \text { onica rubra. Red, Fall, 2' }-1.50 & 22.00 \\ \text { onica Whirlwind. Pure white, Fall, 3' } & 2.50 & 22.00 \\ \end{array}$

pennsylvanica. White, July, 11/2'

pulsatilla. Blue, April, 15" _..._._. 1.80

15.00

pulsatilla rubra. Dark red, April, 12" 1.80

15.00

Anthemis tinctoria. Yellow, July, Aug., 3'_- 1.50

12.00 tinctoria E. C. Buxton.

Lemon yellow, July, Aug. 3'

2.50

22.00

tinctoria kelwayi. Yellow, July, Aug., 3' 1.50

12.00

Aquilegia alpina. Blue, May, June, 1'_-.- 1.50

12.00

caerulea. Blue, May, June, 11/2' -.-- 2.20

18.00

caerulea helenae. Blue, May, June, 2'

15.00

caerulea hybrida. Various, June, 2' -1.50

12.00

canadensis. Scarlet, May, June, 2'_-_- 1.50

12.00

californica. (See formosa truncata.)

chrysantha. Yellow, June, July, 3'---- 1.80

15.00

chrysantha alba. White, June, July, 3' 1.80

15.00

formosa truncata. Various, June, 2' 1.50

12.00

glandulosa. Lilac blue, June, 11/2'

12.00

hybrida. Mrs. Scott Elliott.

Various, June, 2' _._._._._._. 2.20

monstrosa fl. pl. Pink, June, 2'

18.00

20.00

rosea. Long spurred pink, June, 2' _.-- 1.80

15.00

rosea fl. pl. Dbl. Pink, June, 18" -_- 2.20

skinneri. Red and yellow, May 2'_-_- 1.50

12.00

vulgaris. Purple, May, June, 2'_-..-- 1.50

vulgaris nivea. White, May, 2'_-__- 1.50

12.00

vulgaris olympica. Purple, May, June, 2' 1.50

12.00

12.00

15.00

Arabis alpina. White, April, May, 6"_..- 1.80

22.00

Arenaria balearica. White, July, Aug., 3" 2.50

12.00

Arisaema dracontium. Purple, May, 1'_._- 1.50 Armeria cephalotes rubra.

Bright pink, May, June, 6" _._._- 2.20

18.00

12.00

laucheana. Crimson, May, June, 8" -- 1.50

12.00

martima. Pink, May, June, 6" $6^{\prime \prime}$...- 1.50

maritima alba. White, May, June, 6"- 1.50

12.00

mauritanica. Pink, July, August, 8"-- 1.50

12.00

robusta. Crimson, May, June, 6" $6 . . .-1.50$

12.00

Less than five at double the rate per hundred. 
Artemisia abrotanum. Fragrant foliage, 5, $\begin{array}{r}\text { per } 10 \\ 1.50\end{array}$ argentea. Silver foliage, 2' amellus Rud. Goethe.

Lavender blue, Fall, 2' -...-..-_ 3.00

Beauty of Orleans. Bright mauve, Fall, 4' 2.50

Blanchette. Mauve blush, Fall, $4^{\prime}-{ }_{---} 3.00$

Feltham Blue. Blue, Sept., Oct., 3'---ibericus ultramarin. Dark blue, Sept., 3' Joan Vaughan. Dbl. Mauve-blue, Sept., $3^{\prime}$ 
per 10

per 100 arendsi Juno. Purplish pink, July $3^{\prime}-$ arendsi Kreimhilde. Rose, June, July, 2' arendsi Moerheimi. White, July, 5'.arendsi Rose Pearl. Shell pink, July, 3' rosea Queen Alexandra.

Deep pink, July, 3'

3.50

30.00

3.50

30.00

3.50

30.00

3.50

30.00

3.50

30.00

rosea Queen of Holland

Rose pink, July, 3'

3.50

30.00

3.50

30.00

rubella Solferino. Violet pink, July, 3'

3.50

rubella Vesta. Lilac rose, July, $3^{\prime} \ldots$

3.50

30.00

30.00

Astrantia major. Silvery pink, May, 2'_- 2.20

18.00

Aubrietia deltoidea bougainvillei.

Dark blue, Apr., 5" _._._. 2.50

22.00

deltoidea leichtlini. Pink, April, 5"

2.50

22.00

deltoidea purpurea. Purple, April, 5" 2.50

22.00

Baptisia australis. Indigo, June, 4'__... 1.80

15.00

tinctoria. Yellow, June, 3'

15.00

Belamcanda chinensis. Orange, June, 11/2' 1.50

12.00

Bellis perennis alba. White, April, May, 3 "

1.50

12.00

perennis rosea. Pink, April, May, 3" 1.50

12.00

Betonica. (See Stachys.)

Bocconia cordata. Creamy white, Aug., 6'_ 1.50

12.00

Boltonia asteroides. White, Sept., $5^{\prime} \ldots \ldots 1.50$

latisquama. Lavender, August, 5'_._ 1.50

12.00

12.00

Buphthalmum speciosum. Yellow, June, 3' 1.50

12.00

Callirhoe involucrata. Red, all summer, 6" 1.50

12.00

Camassia Quamash. Blue, May, 2' $2^{\prime} \ldots 1.50$

12.00

Campanula alliariaefolia.

White, June, July, 2'_._._. 1.80

carpatica. Blue, July, August, 9" _._ 1.80

15.00

carpatica alba. White, July, Aug., 9" --

1.80

15.00

carpatica Raineri. Dark blue, July, 6"

15.00

grosseki. Blue, all summer, 2'.....

2.50

lactiflora. Light blue, August, 4'....

latifolia. Purplish blue, July, $3^{\prime} \ldots \ldots$

latifolia alba. White, July, 3'_._._. 1.50

latifolia macrantha.

Purplish blue, July, 3' _...... 1.50

12.00

medium. Mixed, June, July, 3'_...- 1.50 
Campanula

medium. Separate colors, June, July, 3' 1.80

medium calycanthema. Separate colors, July, $3^{\prime}$

Carex morrowi. White-edged foliage, $1^{\prime}$-- 2.50

Cassia marilandica. Yellow, July, 3-4'

Catananche caerulea. Blue, June, July, 3' 1.50 caerulea alba. White, June, $3{ }^{\prime}$

Caulophyllum thalictroides. _-_._-_-_-_ 1.50

Centaurea babylonica. Yellow, July, 5'_--- 1.50

dealbata. Red, July, 11/2'_-_._._- 1.80 gymnocarpa. Purple, July, 11/2'------ 1.50 macrocephala. Yellow, July, 3-4' _..- 1.50 montana. Blue, June, July, 2'_-_..-- 1.50 ruthenica. Straw color, July, 4'-_-_- 1.80

Centranthus ruber. Red, all summer, 3'-- 1.50 ruber albus. White, all summer, $3{ }^{\prime}--1.50$

Cephalaria alpina. Yellow, July, 5'_-_-_ 1.50

Cerastium arvense compactum.

White, July, 2" -_._._. 1.50

biebersteini. White, June, 6" -_..-- 1.80

Ceratostigma plumbaginoides. Blue, Fall, 6" 1.80

Chelone glabra. White, or rose tinged,

$$
\text { July, 2' -.-_-_-_-_-_-_-_-_-_-_- } 1.50
$$

lyoni. Deep rose, August, 2' _-_..-- 1.50

Chrysanthemum anemone-flowered -.---- 1.80

Snow Queen-White.

arcticum. White, Fall, 2' 


\section{Chrysanthemum}

hardy button varieties

Baby Marguerite-pure white.

Bronze Button-bronze.

Brown Betty-maroon red.

Diana-pure white.

Golden Climax-jellow.

Irene-Pure white.

Kitty Barno-bronze.

Klondike-bright yellow.

Lillian Doty-pink.

Niza-delicate pink.

Rose Button-rose.

White Doty-white.

hardy large flowering, double, Fall, 4' 1.50

Border Beauty-orange, tipped with gold.

Boston-orange.

Canariense-yellow.

Etna-red.

Farorite-buff.

Golden Queen-jellow.

L'Argentuillais-deep chestnut.

La Danube-pure pink.

Marie Antoinette-pink.

Old Homestead-buff.

Pacific Supreme-white, fading to rose.

Rosea-red.

Ruby King-brown red.

Ruth Cumming-reddish bronze.

Snowclad-white.

Glory of Seren Oaks, Yellow, Sept., 2' 1.80

Normandie. Pink, early Fall, 2'_-.- 1.80

Yellow Normandie. Yellow, early Fall, 2

hardy large flowering, single. Fall, 4' 1.50

\section{Astarte-amber.}

Excelsior-golden yellow.

Lady Smith-bright pink.

Louise-salmon.

Mrs. W. E. Buckingham-salmon pink. 
Chrysanthemum

maximum. White, all summer, 2' $\begin{array}{rr}\text { per } 10 & \text { per } 100 \\ 1.50 & 12.00\end{array}$

maximum Alaska. White, July-Aug., 2' $1.50 \quad 12.00$

maximum King Edward. White,

all summer, 3' _._._._._. 1.50

12.00

maximum Shasta. White, July-Aug., 2' 1.50

12.00

nipponicum. White, Fall, 2'_._._.-.- 2.20

Cimicifuga racemosa. White, July, 5' _-_- 1.50

12.00

Clematis davidiana. Blue, August, $3^{\prime}$ _._._- 2.50

22.00

recta. White, July, $3^{\prime}$ _........... 3.00

25.00

Codonopsis clematidea. White, June, $2^{\prime}$ _..- 1.80

Convallaria majalis. Clumps, White, May, 6" $1.80 \quad 15.00$

Coreopsis grandiflora. Yellow, all summer, $3^{\prime} \quad 1.50$

11.00

lanceolata. Yellow all summer, 2'

11.00

rosea. Rose, August, Sept., 1'_._-_.- 1.50

12.00

verticillata. Yellow, July, Aug., 2'

12.00

Corydalis cheilanthifolia. Creamy white, July, 2' -

30.00

Crucianella stylosa. Crimson pink, July, 8" 1.80

15.00

Delphinium belladonna. Sky blue, all

summer, 4' _-_._. 1.50

12.00

bellamosum. Dark blue, all summer, $4^{\prime} \quad 1.50$

12.00

cashmerianum. Dark blue, July, 1'_-

2.20

chinense. Blue July, 2'_-_._._._.- 1.50

18.00

chinense album. White, July 2'

1.50

elatum. Blue July, 4'

1.50

formosum. Indigo, July, 4' _........ 1.80

12.00

12.00

12.00

formosum coelestinum. Light blue,

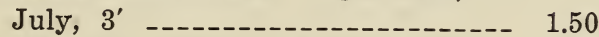

15.00

grandiflorum. Shades of blue, July, 3' 1.50

12.00

12.00

grandiflorum Indigo. Dark blue, July, 4' _._._._._._._._._. 1.80

hybridum Blackmore and Langdon.

Various, July, 4'

25.00

hybridum Gold Medal. Shades of blue,

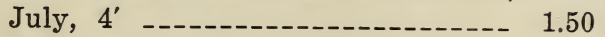

sibirica hybrida. Shades of blue,

July, $3^{\prime}$

Less than five at double the rate per hundred. 
Dianthus allwoodi. Pink, July, 1'___ $\begin{array}{r}\text { per } 10 \\ 1.80\end{array}$

arenarius. White, July, 10"

barbatus. (Single Sweet William).

mixed colors, June, July, 1'_-_-- 1.50

barbatus alba. White, June, July, 1'_-- 1.50

barbatus atrococcineus. Crimson,

June, $1^{\prime}$

12.00

barbatus fl. pl. (Double Sweet William). mixed colors, June, July, $1^{\prime}$-_-_-- 1.50

barbatus Holborn Glory. Mixed, June, $1^{\prime} \quad 1.50$

barbatus Newport Pink. Finẹ pink, June, $1^{\prime}$

barbatus nigricans. Dark velvety red, June, $1^{\prime}$ _._-_-_-_-_-_-_-_-_- 1.50

barbatus rosea. Pink, June, 1' -..---

barbatus Salamoni. Salmon, June, 1' 1.50 12.00 barbatus Sutton's Scarlet. Crimson, June, $1^{\prime}$

caesius. Rose pink, June, July, 9" _-_- 1.50

caryophyllus. Double, mixed, all summer, $9^{\prime \prime}$

Chabaud. Pink, June, July, 12" -...-- 1.80

chinensis heddewigi. Mixed, June, July, 9"

deltoides. Pink, June, 9"

diadematus. Pink, June, 10"

1.80

graniticus. Purple, July, 6"

hardy pinks. Single, mixed, all summer, 9"

latifolius atrococcineus. Crimson, summer, 1'

plumarius. (Scotch Pink) mixed, summer, 8"

plumarius fl. pl. (Double Scotch Pink) mixed, all summer, 9" _._._._._. 1.80

Abbotsf ord. Crimson, all summer, 9"-

Cyclops. Dark rose, June, July, 9"

Delicata. Rose, June, July, 9" -..-

Elizabeth Peters. Pink, June, July, 9" 
Dianthus plumarius

Elsie. Bright rose, June, July, 9" $\quad \begin{array}{r}2.20 \\ 20\end{array}$

per 109

Etoile de Lyon. Crimson, June, $1^{\prime}--3.50$

18.00

Homer. Rosy red, June, July, 9"--

30.00

Her Majesty. Dbl. White, June, July, 9"

2.20

18.00

Souv. de. Sales. Dbl. Pink, June, 9" 1.80

15.00

Variegated Reserve.

White, mottled red, June, July 9" 2.20

15.00

White Reserve. White, June, July, 9" 1.80

18.00

15.00 speciosa. Pink, July, 10"

15.00

superbus. Lilac, June, July, 12" ---- 1.80

15.00

Dicentra eximea. Rose, all summer, 1'_-_- 2.50

18.00

Dictamnus albus. White, June, 2'

albus ruber. Red, June, 2' _......- 3.00

Digitalis ambigua. Yellow, June, July, 3'-- 1.50

ferruginea. Yellow, July, 4-6' -..-- 1.50

12.00

gloxinaeflora. Mixed, June, July, 3'_- 1.50

12.00

lanata. Creamy yellow, June, 3'_...- 1.50

12.00

purpurea. Mixed, June, July, 3'_-..- 1.50

12.00

purpurea maculata. Spotted, June,

July, 18" _._-_._-_._. 1.50

12.00

purpurea monstrosa. Various, June,

July, 3' _..._._._._._. 1.50

purpurea, rose. June, July, 3' _.... 1.50

12.00

12.00

purpurea, white. June, July, $3^{\prime} \ldots \ldots-.-$

1.50

12.00

Doronicum clusi. Yellow, Apr., May, 18" 4.00

30.00

plantagineum excelsum.

Yellow, Apr., May, 5'

4.00

30.00

Echinacea purpurea, Cone Flower. Reddish purple, July, August, 3' _..._..- 1.50

12.00

12.00

Echinops ritro. Deep steel blue, July, 3' 1.50 sphaerocephalus. Pale blue, July, 5'_- 1.50

12.00

Elymus giganteus. Wild-rye, 3-4' _-_._- 3.00

25.00

Epilobium angustifolium. Rose, August, 4' 2.20

Erianthus ravennae. Ravenna Grass, 6' $6^{\prime}-2_{-50}$

Erigeron coulteri. White, July, 15" --_--- 1.50

12.00

glabellus. Violet, June, July, 1'_-..- 1.50

12.00

glaucus. Mixed, June, July, 1' _...- 1.50

12.00

speciosus. Rich purple, June, July, 2' 1.50

12.00

Eryngium planum. Steel Blue, July, Aug., 3' 1.50 
per 10

Erysimum pulchellum. Lemon, May, June, 6" 1.50

per 100

12.00

Eulalia gracillima. Japan Rush, 4-6'_-_-- 1.50

12.00

japonica variegata. $4-6^{\prime}$ _........- 1.80

15.00

zebrina. Zebra Grass, 4-6' _-_-_-_-- 1.80

15.00

Eupatorium ageratoides. White, August, 3' 1.50

12.00

coelestinum. Blue, Sept., Oct., 18"--_- 1.50

12.00

fraseri. White, Aug., Sept., 18"-_-_- 1.50

12.00

purpureum. Purple, Aug., Sept., 5'-- 1.50

12.00

Euphorbia corollata. White, July, Aug., 2' 1.80

15.00

cyparissias. Yellow, May, 2" --_-_-- 2.20

18.00

Festuca glauca. Fescue Grass, June, 10" 1.50

12.00

Fragaria indica. White, May, 6"-_-_-_-_- 1.80

Funkia. (See Hosta).

Gaillardia grandiflora. Yellow and Crimson,

all summer, 2' _-_-_-_-_-_-_-_ 1.50

11.00

grandiflora Bosseleari.

Yellow and crimson, all summer, 2' 1.80

Galega officinalis. Blue, June, July, $3^{\prime}$-.-- 1.50

15.00

12.00

officinalis hartlandi. Bluish White,

July, 3' -

12.00

Galium boreale. White, July, 11/2' _-_.-- 1.80

Gentiana alba. White; August, 2'_-_-_-- 1.80

15.00

andrewsi. Blue, August, 2' _-..- 1.80

15.00

15.00

Geranium ibericum. Mauve blue, May,

June, 2' -_._-_-_-_-_-_-_-_ 1.80

lancastriense. Mauve, May, June, 1'-- 2.20

15.00

18.00

pratense album. White, July, Aug., 2' 1.80

sanguineum. Red, June, July, 2'---- 1.50

12.00

Geum atrosanguineum. Dark red, all sum-

mer, 11/2' -

15.00

Lady Strathedon. Orange,

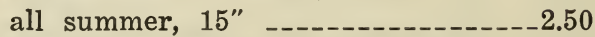

22.00

18.00

Mrs. Bradshaw. Double red, all'summer, 1' 2.20

Gypsophila acutifolia. Pink, July, 2-3'

12.00

paniculata. White, July, Aug., 2-3'_-- 1.50

12.00

paniculata fl. pl. Dbl. white, July,

Aug. 3' --_- 3.00

25.00

repens. Bluish white, all summer, $4^{\prime}$-- 1.50

12.00

repens rosea. Pink, July, Aug., 2-3'_- 1.80

Helenium autumnale superbum. Yellow,

Sept., 5-6'

hoopesi. Orange, June, July, 3'_-_-_ 1.50 
Helenium

Riverton Beauty. Lemon, Aug., Sept., 5' $\begin{array}{rr}\text { per } 10 & \text { per } 100 \\ 2.20 & 18.00\end{array}$

Riverton Gem. Old Gold, Sept., Oct., 4' $2.20 \quad 18.00$

rubrum. Brick red, Sept., 4'_-_-_-- $1.80 \quad 15.00$

Helianthella quinquenervis. Yellow,

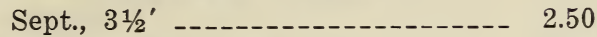

uniflora. Yellow, Sept., 3'_-_-_-_-_ 2.50

Helianthemum croceum. Saffron, June,

$$
\text { July, 9" -_._-_._- } 1.50
$$

12.00

Fire Ball. Red, July, Aug., 12"

15.00

mutabile. Flesh, May, June, 12"--.-- 1.80

15.00

Helianthus atrorubens. Yellow, Fall, 6' $6_{--} 1.50$

12.00

maximiliani. Yellow, Sept., $6^{\prime}$ _-_-_-- 1.50

12.00

mollis grandiflorus. Yellow, Aug.,

Sept., 4' -_. 1.50

12.00

orgyalis. Bright yellow, Oct., 6-8' $8^{\prime} \ldots 1.50$

12.00

rigidus. Yellow, August, 3'_-_-_-_-- 1.50

Soleil d'Or. Dbl. yellow, August, 4' 1.80

Wooley Dod. Deep yellow, Sept., $7^{\prime}{ }_{--} 1.50$

12.00

15.00

12.00

Heliopsis excelsa. Deep yellow, Aug., 3'-- 2.50

pitcheriana. Orange, July, Aug., 3'-- 1.50

18.00

zinniaeflora. Dbl. Yellow, Aug., 4'_-_- 1.80

12.00

15.00

Hemerocallis Apricot. Apricot color,

$$
\text { June, 2' _-_-_-_-_-_-_._-_._. } 1.50
$$

aurantiaca. Orange, June, July, 21/2 -- 2.50

22.00

dumortieri. Orange, June, 2' _-_._-_ 1.50

12.00

florham. Golden yellow, June, 3'_-.- 3.00

25.00

fulva. Bronze, August, 3' _-_._-_ 1.50

12.00

Gold Dust. Indian yellow, June, $2 \frac{1}{1} 2^{\prime}-$

1.50

kwanso. Reddish orange, June, 21/2' -- 1.50

12.00

12.00

luteola. Orange, June, 2' _-.._-_._- 1.80

15.00

middendorffi. Orange, June, 3' -.... 1.50

12.00

minor. Yellow, June, 2'_-_-_-_- 1.50

12.00

Orange Man. Deep orange, June, 2'-- 1.50

12.00

Sovereign. Rich orange, June, 11/2' -- 1.50

12.00

thunbergi. Lemon yellow, June, $2-3^{\prime}$-- 1.50

12.00

Less than five at double the rate per hundred. 
Hepatica acutiloba. Light blue, March, 4" 1.50

Hesperis matronalis. Purple, June, July, 3' 1.50

Heuchera brizoides. Red, June, July, 2' --

Hibiscus Mallow Marvels. Mixed, July and August, 5' _.......... 1.50

Mallow Marvels. Separate colors, Aug., 5'

Mallow Marvels. Giant Red, Aug., 5'_

moscheutos crimson eye. White, red eye, Aug., 5' _..... 1.50

Hieracium aurantiacum. Orange, summer, 6" 1.50

12.00

Hosta caerulea. Blue, July, 11/2'

12.00

lancifolia. Blue, July, 2'_._._._. 1.00

12.00

marginata. White bordered, Aug., 2' --

ovata. Lavender, June, July, 1-2'_.--

sieboldiana. Silvery foliage _......-

sub-cordata grandiflora. White, Aug. 18"

undulata variegata. White foliage, 2'

moserianum. (See Shrubs).

Hyssopus officinalis. Purple, Aug. 18"

Iberis gibraltarica. Delicate lilac, May, 11/2' 2.20

18.00

sempervirens. White, May, June, 8" --

sempervirens Climax. White, May, 6" 2.50

tenoreana. Purplish white, April, 6" 2.50

Incarvillea delavayi. Rosy purple, June,

$$
\text { July, 2' }
$$

18.00

Inula ensifolia. Yellow, July, Aug., 8" -germanica. May, June, 11/2-2'.

Alcazar. Violet, purple falls_._._. 3.00

Aurea. Yellow _-_._._._. 1.80

Blue Bird. Indigo blue _....... 1.50

Canary Bird. Yellow _.......... 1.50 
germanica.

Celeste. Delicate blue _-_._-_-_-_- 1.50

per 100

Florentina, Pale blue -.-.-.-- 1.50

12.00

Florentina alba. White _-_-_-_-_-- 1.50

12.00

Gracchus. Yellow and purple -.---- 1.50

12.00

Her Majesty. Lilac pink _-_-_-_--- 1.50

12.00

Honorabilis. Yellow, brown falls -- 1.50

12.00

King of Iris. Yellow, brown falls -- 3.50

12.00

King Edward. Red violet _-_._-_- 1.50

30.00

Lavender Queen. Lavender _..-_- 1.50

12.00

Lohengrin. Lilac rose -..-_-_-_-_ 1.50

12.00

Loreley. Light yellow, blue falls _- 1.50

12.00

Mad. Chereau. White, tinged blue 1.50

12.00

Mad. Paquitte. Bright rose claret_- 1.50

12.00

Midnight. Dark blue _-_-_-_-_-_ 2.20

12.00

Mithras. Yellow, wine red falls ... 1.80

18.00

Mrs. Allen Gray. Pale rose-mauve - 1.50

15.00

Mrs. H. Darwin. Pure white _...-_ 1.50

12.00

Niebelungen. Fawn yellow _...-- 1.80

12.00

Pallida Dalmatica. Lavender _...-- 2.20

15.00

Pallida speciosa. Light blue _-..-- 1.50

18.00

Parisensis. Dark blue _-_-_-_-_-_ 1.50

12.00

Princess Victoria Louise. Sulphur yel-

low, rich violet falls _-_.--_- 2.20

12.00

Princess of Wales. Pearly white -- 1.80

18.00

15.00

Queen of Gypsies. Yellow standards, maroon falls

Rhein Nixe. White, violet falls _-_- 2.20

Silver King. Silvery white -..--.--

Spectabilis. Purple --.--_-_-_-_-_ 1.50

12.00

Trautlieb. Delicate pink -.---_---- 1.80

12.00

Victorine. White, mottled blue -.-- 1.80

15.00

intermedia hybrids. May $18^{\prime \prime}$

1.50

12.00

Gerda. Creamy yellow, darker falls.

Halfdan. Creamy white.

Ingeborg. Ivory white.

Helge. Light citron.

Walhalla. Light blue, purple falls.

kaempferi. Japanese Iris. July, 2-3' 2.50 18.00 Antelope. Light lavender.

Less than five at double the rate per hundred. 
Iris kaempferi.

Aoigata. Light purple, with darker halo.

Chadai. Clear white, creamy standards.

Exquisite. Blue in light and dark shadings.

Furomon. White, purple shadings.

Gold Bound. White, yellow shadings.

Hannaoi. Gray, yellow blotches and blue veins.

Hinodeuzuru. White, blue shadings.

Idzumigawa. Gray, yellow blotches and blue veins.

Komochiguma. Dark bluish purple.

Kumonoobi. Clear purple, white halo.

Kurokumo. Purple overlaid with dark blue, yellow blotches.

Manadzuru. White, yellow blotches.

Norma. Deep purple.

Onigashima. Brief violet purple.

Purple and Gold.

Royal. Mahogany red.

Shigano-uranami. Red lavender, white halo.

Uchiu. Crimson purple with few white veins.

Warai botei. Lavender blue, light blue halo.

new hybrids.

per 10

Candalabra. Mauve, violet falls _- 1.80

Dorothea. Mauve, soft blue falls -- 1.80

Isolene. Lilac pink, old rose falls_- 2.50

Jeanne d'Arc. White _-_._-_._- 1.80

Nuee d'Orange. Slate gray with

bronze and purple falls _.......- 1.80

Tamerlane. Light blue, darker falls__2.50

pseudacorus. Yellow, June, 3' _-..-- 1.50

pumila alba. Dwarf, White, April, 9" 1.50

pumila caerulea. Dwf., Blue, April, 9" 1.50

pumila violacea. $D w f$., violet, April 9" 1.50

siberica. Purplish blue, June, 3'_-_- 1.20

siberica alba. White, June $3^{\prime}$ _....- 1.20

Stewart. Dwarf Yellow, April 9"_-_ 1.80

verna. Blue, May, June, 6" 6 _._-_. 1.50

versicolor. Blue, June, 2' _-..-_- 1.50

Kniphofia pfitzeri. Coral, Aug., Sept., 4' 2.20 
Lamium maculatum. Lavender, July, Aug., 8" $\begin{array}{r}\text { per } 10 \\ 3.00\end{array}$

Lathyrus latifolius. Pink to Red, July, $6^{\prime}{ }_{--} 1.50$

Lavandula officinalis. (Sweet Lavender). July, 2' (-

Lavatera cashmeriana. Pink, July, $3^{\prime}$-.-- 1.50

Liatris pycnostachya. Purple, Aug., Sept. 4' 1.50

Lilium auratum. (Gold Band Lily). White. with gold band, July, Aug., 3' batemanniae. Salmon red, July $3^{\prime}$-- 3.00 canadense. Yellow to Red, June, July, 3' 1.50 candidum. White, June, 3 '_-_...-.- 4.50 12.00 elegans. Shades Yellow and Red, July, $2^{\prime}$ henryi. Yellow, July, 2' _......... 5.00 pardalinum. Scarlet and Yellow, 2' -- 3.00 philadelphicum. Orange red, June,

25.00

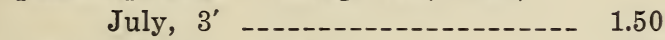
regale. White, Aug., 4' _._._._._. 7.50 superbum. Orange, July, Aug., 5' -..30.00 tigrinum. Orange spotted, Aug., 4' -umbellatum. Scarlet red, July, 2' --

Limonium latifolium. Blue, July, Aug., 2'

Linum narbonnense. Blue, June, July, 2' 1.50 perenne. Blue, June, July, 11/2' -..- 1.50

Lobelia cardinalis. Scarlet, Aug., Sept., 3' 1.80 siphilitica. Blue, September, 3' -.-.- 1.50

Lupinus polyphyllus. Blue, June, July, 3' 2.50 polyphyllus albus. White, June, July, 3' 2.50

Lychnis alpina. Rose color, June, 1'_...- 1.80 chalcedonica. Scarlet, July, 3'_-_.-- 1.50 coronaria. Crimson, June, 2' _.....- 1.50 
Lychnis

per 10

per 100

coronata sieboldi. White, July, 1' _- 1.80

15.00

floscuculi. Red, June, $1 \frac{1 / 2^{\prime}}{} \ldots \ldots$

12.00

flosjovis. Pink, June, $1^{\prime}$ _._._-_-_- 1.50

12.00

haageana. Scarlet, June, July, 1' _-.- 1.50

12.00

viscaria splendens. Red, May, June, 1'

1.50

12.00

viscaria splendens fl.pl. Red, June, 1'

1.50

12.00

Lysimachia clethroides. White, July, Aug., 3'

1.80

15.00

nummularia. Yellow, June, Aug., 4' 1.50

12.00

Lythrum salicaria roseum. Rose, July, 4'

1.50

12.00

virgatum. Deep rose, July, Aug., 11/2'

12.00

Malva alcea. Rosy purple, July, Aug., 3'

1.50

moschata. Rose, July, Aug., 2'_-..--

1.50

12.00

Matricaria parthenoides. White, May, 1'_-

12.00

12.00

Mentha piperita. Peppermint, Purple, 2' 1.50

12.00

Mertensia virginica. Purplish blue, March,

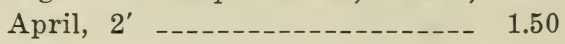

Miscanthus. (See Eulalia).

Mitchella repens. White shaded pink,

March, 4" _._-_._- 1.80

15.00

Monardi didyma. Red, July, Aug., 3' --- 1.50

didyma Cambridge. Scarlet, July, Aug., 3' 1.50

12.00

didyma pink. July, Aug., $3^{\prime}$ _._._- 2.20

18.00

didyma Sunset. Mahogany, July, Aug., 3'

2.20

didyma splendens. Scarlet, July, Aug., 3'

1.50

didyma violacea. Violet, July, Aug., 3' 1.50

18.00

12.00

12.00

Myosotis alpestris. Blue, all summer, 8" - 1.50

12.00

alpestris alba. White, May, June, $8^{\prime \prime}$-- 1.50

12.00

palustris. Blue, April, May 6" _..._ 1.50

12.00

Nepeta hederacea. Blue, May, 2" _...... 1.50

12.00

hederacea variegata. Blue, May $2^{\prime \prime}$-- 1.50

12.00

mussini. Blue, June, July 1' _....-- 2.20

18.00

Oenothera fruticosa youngi. Lemon, June,

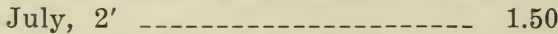

12.00

lamarckiana. Yellow, July, Aug., 4' -- 1.50

12.00

missouriensis. Yellow, July, Aug., 6" 1.80

15.00

speciosa. White, July, Aug., 11/2' _- 1.50

12.00

Pardanthus. (See Belamcanda).

Pachysandra terminalis. White, May, $3^{\prime \prime}$

2 year from pots 
Paeonia officinalis rosea. Rose pink _-.-- 7.50

officinalis rubra. Red _... 7.50 sinensis. Strong plants, 3-5 eyes.

Candidissima. White, creamy center 5.00

Couronne d'Or. White, yellow center 7.50

Delacheii. Crimson _._. 5.00

Duchess de Nemours. Creamy white 7.50 60.00

Edulis. Deep rose _._._._._. 5.00

Felix Crousse. Brilliant red _._.- 10.00 90.00

Festiva alba. White 45.00

Festiva maxima. Finest early white 10.00 80.00

Gen. McMahon. Deep violet red_--- 10.00

Gigantea. Rose pink

Humeii. Deep rose _._._._._-_ 5.00

Jeanne d'Arc. Tender pink, center rosy white

La Tulip. Flesh pink, shading to white

L'Eclatante. Dazzling red _._._-_ 7.50

L'Esperance. Rose pink _..._-_-_- 7.50

L'Indispensible. Shell pink _._._- 7.50

Louis Van Houtte. Deep crimson _- 5.00

Livingstone. Soft pink

Mad. de Galhau. Dark pink _.-- 7.50

Mad. de Verneville. Sulphur white, with some carmine _._._._-_-_ 7.50

Mad. Lebon. Cherry _._._.- 7.50

Marie Lemoine. Creamy white --_ 7.50

Modeste Guerin. Deep rose _..._- 5.00 60.00 60.00 60.00 60.00

Mons. Jules Elie. Pink with darker

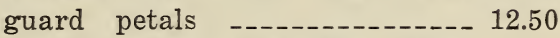

Souv. de l'Exposition Universelle. Brillant cherry with silver reflex _-_- 7.50 60.00

Triumph de Paris. Light pink, yellow center

single. Named colors, red, white, pink 16.00 tenuifolia fl. pl. Scarlet _-_____-_ 10.00

Papaver bracteatum. Blood red, June, 2' -- 1.50 nudicaule. All colors, summer, 8" -..- 1.50 orientale. Orange scarlet, June, 2' -- 1.50 
Papaver

Fire King. Red, June, 2'

Goliath. Fire red, June, 2'__._._- 3.00

Queen Alexandra. Salmon, June, 2' 3.00

Princess Victoria Louise, Salmon, June, 2' -_._- 3.00

Pentstemon barbatus. Scarlet, July $3^{\prime} \ldots 1.50$

12.00

digitalis. White, August, 3' _..._.- 1.80

15.00

grandiflorus. Lilac blue, July, $3^{\prime}$-_.- 2.50

hirsutus. Rosy purple July, Aug., 2 -- $1.50 \quad 12.00$

Phalaris arundinacea variegata. Ribbon grass 1.50

11.00

Phlox amoena. Pink, May, 4" _-_-_-_-_ 1.50

12.00

divaricata. Lavender, May, June, 1' -- 1.50

12.00

maculata. Purplish red, May, June, 4' 1.50

12.00

ovata. Red, May, June, 1' _........- 1.80

15.00 paniculata $2-3$ '

Aloise Louise. Lilac _-_-_-_-_-_-_ 1.50

Antonin Mercie. Lilac, white center-- 1.50

Athis. Salmon pink _-_-_-_-_-_- 1.50

12.00

12.00

B. Compte. Rich French purple.-

2.20

Bridesmaid. White, red eye _-..-- 1.50

12.00

18.00

Caran de Ache. Bright carmine rose 1.50

12.00

12.00

Champs. Elysees. Rich purpish crim-

$$
\text { son }
$$

1.80

15.00

Coquelicot. Orange scarlet _..._... 1.80

Eclaireur. Magenta, white eye._-_-_ 1.50

15.00

Etna. Scarlet _-_-_-_-_-_-_-_- 2.20

Eiffel Tower. A beautiful pink ---- 2.20

Elizabeth Campbell. Salmon pink -- 2.20

Fernand Cortez. Coppery red _-..-- 1.80

Frau Anton Buchner. White _....- 1.50

Frau Von Lassburg. White _.....-. 1.80

G. A. Strohlein. Orange scarlet, red

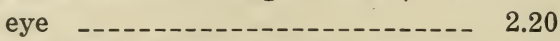

Gefion. Peach blossom pink, rose eye 1.80

Grideur. Pink, crimson center ---- 1.80

Henri Murgher. White, magenta eye 1.80

J. H. Slocum. Red _..._-_._-_ 1.80

Johnson's Favorite. Salmon rose_-_- 1.80

12.00

18.00

18.00

18.00

15.00

12.00

18.00

15.00

15.00

15.00

15.00

15.00

Less than five at double the rate per hundred. 
Phlox paniculata.

La Vague. Silvery rose per 10

per 100

Mad. Benzanson. Crimson _-..---- 1.80

12.00

Maid Marian. Soft lavender _-_-_-_- 3.00

15.00

Mrs. Jenkins. Pure white_._-_-_-- 1.50

Mrs. Ingalls. Shell pink _-_-_-_-- 1.50

Mrs. Milly van Hoboken. Soft pink 2.20

M. P. Langier. Red _-_._._. 1.80

Miss Lingard. White _-_._-_._-_-_- 1.50

Pantheon. Deep salmon rose _-...- 1.50

Peachblossom. Shell pink_-_-_-_-_- 1.50

25.00

12.00

12.00

18.00

15.00

12.00

12.00

Pres. Poincare. White rose eye---- 1.80

Rheinlander. Salmon pink, claret eye 1.80

Richard Wallace. White, crimson eye 1.50

Rynstroom. Bright crimson pink _--- 1.80

12.00

15.00

15.00

12.00

R. P. Struthers. Carmine, claret red

15.00

eye -_-_-_-_-_-_-_-_-_- 1.80

Siebold. Orange scarlet _-_._-_-_- 1.80

Sir Edward Landseer. Bright crimson 1.80

Tapis Blanc. Dwarf, white _-..-_-_ 1.50

Thor. Deep salmon pink__-__-_-_-_ 2.20

W. C. Egan. Soft pink____-_-_- 1.80

White Lady. Pure white _....... 1.50

Widar. Light reddish violet, white eye 1.80

reptans. Lilac, May, 6-12" _..._-_._ 1.50

stellaria. Creeping, May, 4" _..._-_- 1.50

subulata alba. White, April, May, 4" 1.50

subulata lilacina. Light blue, April,

May, 4" -_._- 1.80

15.00

15.00

15.00

12.00

18.00

15.00

12.00

15.00

12.00

12.00

12.00

15.00

subulata moerheimi. Carmine pink,

April, May, 4" _._._._._._. 1.80

15.00

subulata nelsoni. White, April, May, 4" 1.80

subulata rosea. Pink, April, May, 4" -- 1.50

15.00

12.00

subulata The Bride. White, red center,

$$
\text { Apr., May, 4" --_-_-_-_-_-_ } 1.80
$$

15.00

Physalis francheti. Red pods, Oct., 2' -.- 1.50

12.00

Physostegia virginiana. Lilac, August, 3' -- 1.50

12.00

virginiana alba. White, August, $3^{\prime}$-- 1.50

12.00

Platycoden grandiflorum. Blue, summer, 2' 1.50

12.00

grandiflorum album. White, summer, 2' 1.50

12.00

mariesi. Deep blue, summer, $1^{\prime}$-.-- 1.50

12.00

Less than five at double the rate per hundred. 
Plumbago larpentae. (See Ceratostigma).

Polemonium caeruleum. Deep blue, June, July, 11/2' _-_._. 1.50

caeruleum album. White, June, July, $1 \frac{1}{2^{\prime}}$

reptans. Blue, May, June, 6"

richardsoni. Sky blue, May, June, 6" 1.50

Polygonum amplexicaule. Red, Sept., 5' -- 1.80

compactum. White, Aug., Sept., 11/2' 1.50

cuspidatum. White, Aug., Sept., 11/2' 1.50

12.00

Potentilla hybrida fl. pl. Mixed, June,

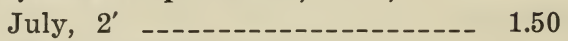
12.00

hyb. Gibson's Scarlet. Red, July, Aug., 2'

hyb. Mons. Rouillard. Crimson, July,

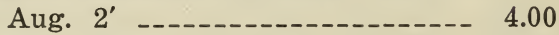
nepalensis. Showy red, May, June, 2' 1.50 12.00 rupestris alba. White, June, July, 2'_- 1.50

Primula acaulis. Yellow, May, 9" cashmeriana. White, May, 8" _._._-_ 1.80 15.00 japonica. Crimson, May 9" _._._-_-- 1.80 15.00 pulverulenta. Yellow, May, 8" -...- 1.80 15.00 veris. Yellow, April, May, 9"_._._._ 1.50

Pulmonaria saccharata. Violet, Apr., May, 8" 3.00 Pyrethrum roseum. Various, May, June, 1' 1.50 roseum James Kelway.

Salmon pink, May, June, 1'_-_-- 3.00

uliginosum. White, September, $5^{\prime}$-_-- 1.50

12.00

Ranunculus acris fl. pl. Dbl. Buttercup, June, $1^{\prime}$

Rosemarinus officinalis. Light blue, April, 4" 1.80 15.00

Rudbeckia Autumn Glory. Yellow, Aug.,

Sept., 6'

hirta. Yellow, Aug., Sept., 3'

12.00

laciniata. (Golden Glow) Yellow, Aug., 6'

1.50 nitida. Single yellow, Aug., Sept., 6' -speciosa. Orange yellow, July, Aug., 2' 1.50 12.00 11.00 12.00 subtomentosa. Lemon yellow, August,

Sept. 
Ruta graveolens. Yellow, all summer, 21/2' 2.50

Salvia azurea grandiflora. Blue, Aug., 6' 61.50 turkestanica. White, tinted pink, Aug., 2' 1.80 uliginosa. Blue, August, 2' _..._-_. 1.50

Sanguinaria canadensis. White, April, 8" -- 1.50

Saponaria ocymoides. Pink, summer, 9"_-- 1.50 ocymoides alba _..._._.

Saxifraga cordifolia. Rosy purple, April, May 1' _._._._. 3.00

25.00

crassifolia. Rosy pink, April, 1' _..- 3.00

25.00 grandiflora. Pink, April, 1' _-..-.--

lingulata rosea. Pink, April, 1' _..- 3.00

25.00

lingulata leichtlini. Rose, Apr., 1' _... 3.00

25.00 purpurea. Rosy purple, April, 1' _... 3.00

25.00

25.00

Scabiosa caucasica. Lavender, all summer, 1' 2.50 japonica. Lavender, Aug., Sept., 18" 2.20

18.00

Sedum acre. Yellow, June, July, 4" _..... 1.50

album. White, July, 4" -._-_-_-_- 1.50

12.00

ewersi. Pink, Aug., Sept., 6" _...-_- 1.50

kamtschaticum. Yellow, July, 6" _..- 1.50

12.00

maximowiczi. Yellow, July, Aug., 1' 1.50

sexangulare. Yellow, June, July, 6" -- 1.50

12.00

12.00

sieboldi. Pink, July, August, 1' _..- 1.80 spectabile. Pink, Aug., Sept., 11/2' -- 1.50

12.00

15.00

spectabile Brilliant. Crimson, Sept., 11/2' 1.50

12.00

stolonif erum. Crimson, July, Aug., 6" 1.50

12.00

12.00

stolonif erum coccineum. Crimson, Aug., 6" -...- 1.50

12.00

Sempervivum arachnoideum. Red, June, 4" 2.20

arenarium. Yellow, July, 6" _..._._ 2.20

18.00

tectorum violaceum. Violet red, June, 4" 2.20

18.00

18.00

18.00

Senecio clivorum. Yellow, Aug., Sept., 18" 2.20

12.00

Sidalcea candida. White, July, Aug., 3' -- 1.50

18.00

Rose Queen. Rose pink, July, Aug., 4' 2.20

Silene orientalis. Pink, July, 2' _..._-_- 1.50

12.00 schafta. Bright pink, July, 6" -..- $1.50 \quad 12.00$

Less than five at double the rate per hundred. 
per $10 \quad$ per 100

Silphium perfoliatum. Yellow, July, 6'

Smilacina racemosa. White, April, 2-3' -- 1.50

12.00

Solidago canadensis. Yellow, Fall, 4-5'

rigida. Yellow, Fall, 3-4' -

12.00

shorti. Yellow, Fall, 4' -_-_-_-_-_ 2.50

22.00

Spirea aruncus. White, June, July, 3-5' -- 1.80

15.00

chinensis. Silvery pink, June, July, 2' 1.80

eximea. Pink, June, July, 2' _-_-_- 3.50

15.00

filipendula. Single, White, June,

July, 1' _........... 1.80

filipendula fl. pl. White, June, July, 1' 2.20

lobata. Pink, July, 4' -._._-_._-_- 2.20

palmata. Rosy crimson, June, July, 2' 1.80

ulmaria fl. pl. White, June, 3-4'_-_--- 1.80

venuta magnifica. Deep pink, July, $3^{\prime}--3.00$

30.00

15.00

18.00

18.00

15.00

15.00

25.00

Stachys lanata. Purple, June, July, 11/2' -- 1.50

12.00

grandiflora superba. Rose, July, 2' -- 1.50

12.00

Statice. (See Limonium).

Stellaria holostea. White, May, June, 11/2' 1.50

12.00

Stenanthium robustum. White, August, 3' 2.50

Stokesia laevis. Lavender, Aug., Sept., 1' 1.50

12.00

laevis alba. White, Aug., Sept, $1^{\prime}$-_-- 1.80

15.00

Teucrium chamaedrys. Rose, August, 1' -- 1.50

12.00

Thalictrum adiantifolium. Yellow, June, 9" 1.80 aquilegifolium. White, June, 3' _..- 1.80

15.00

15.00

aquilegifolium purpureum. Purple,

June, 3'

baicalens. Yellow, June, 4' _...... 1.80

dipterocarpum. Lilac, June, 4' -.- 2.50

glaucum. Golden-yellow, June, 2' -- 2.20

Thermopsis caroliniana. Yellow, June, 6' 1.50

mollis. Yellow, June, July, 2-3' -.- 1.50

15.00

22.00

18.00

12.00

12.00

Thymus serpyllum. White, June, 4" --- 1.50

12.00

serpyllum citriodorus. Purple, June,

July, 3-5"

serpyllum coccineus. Scarlet, June, 4" 1.50

12.00

serpyllum lanuginosus. Rosy purple,

June, July, 5" _._._. 1.50

12.00

vulgaris. Lilac, June, July 2' _..._ 1.50

12.00

Less than five at double the rate per hundrea. 
per 10

Tiarella cordifolia. Creamy white, June, $8^{\prime \prime} 1.50$

Trillium grandiflorum. White, May, 1'_---- 1.50

Tritoma. (See Kniphofia).

Trollius asiaticus. Rich orange July, Aug., 2' _...-..-. 4.00

35.00

europeus. Citron yellow, July, Aug., 1' 4.00

35.00

Tunica saxifraga. Light pink, June, July, 6" 1.50

12.00

Valeriana officinalis. Rose, June, July, 5' 1.80

15.00 officinalis alba. White, all summer, 5' 1.80

15.00

Verbascum olympicum. Yellow, July, Aug., 5' 1.80

15.00

Veronica alpestris. Pale blue, May, June, 3' 1.50 elegantissima. Blue, July, Aug., 2' -.-- 1.50 incana. Pale blue, July, Sept., 11/2' -- 1.50

longifolia subsessilis. Blue, Aug.,

Sept., 2' _-

15.00

12.00

pectinata rosea. Pink, May, June, 6" -- 1.50 pulchella. Blue, May, 1'_-_._-_._-_ 1.50

12.00

rupestris. Blue, June, 6" _-_._._- 1.50

12.00

spicata. Blue, July, Aug., 4' _.....-- 1.50

12.00

spuria. Blue, June, 3'

teucrium prostrata. Blue, June, 1'-- 1.50

12.00

12.00

virginica. Pale blue, August, 4' -...- 1.50

12.00

12.00

Viola alba. White, May, 6"

cornuta Admiration. Purple, all

summer, $6^{\prime \prime}$

cornuta alba, type. White, all summer, $6^{\prime \prime}$

cornuta atropurpurea, type. Purple, 6" 1.50

cornuta Blue Perfection. Blue, all summer, 6 "

cornuta G. Wermig. Violet, all summer, 6" 6 _. 1.50

12.00

cornuta Lutea Splendens. Yellow, all summer, 6"

cornuta Mauve Queen. Mauve, all summer, 6" 
Viola

gracilis. Deep violet, summer, $1^{\prime}$-.-- $\begin{array}{r}\text { per } 10 \\ 1.80\end{array}$

per 100

odorata. Blue, April, May, 6"-_-_- 1.50

15.00

odorata Gov. Herrick. Blue, May, 6" --

odorata Princess of Wales. Violet, May, 6"

2.20

12.00

wellsiana. Various, all summer, $6^{\prime \prime}$----

2.20

18.00

2.20

18.00

18.00

Yucca filamentosa. White, June, July, 7'

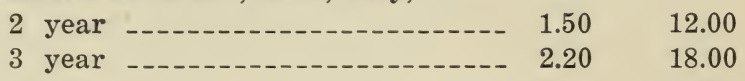

Less than five at double the rate per hundred.

\section{Hardy Ferns}

Adiantum pedatum. Maiden Hair Fern .25 $\quad 180$

per 100

$\begin{array}{rrr}.25 & 1.80 & 12.00\end{array}$

Asplenium Felix Faemina. Lady Fern. $\quad .25$. $1.80 \quad 12.00$

Dennstedtia punctilobula. Hay-scented

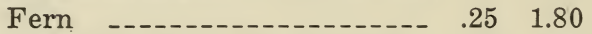

12.00

$\begin{array}{lllll}\text { Dryopteris spinulosum. Wood Fern }- \text { - } & .25 & 1.80 & 12.00\end{array}$

Dryopteris thelypteris. Shield Fern -- $.25 \quad 1.80 \quad 12.00$

Onoclea sensibilis. Sensitive Fern --_- $\quad .25 \quad 1.80 \quad 12.00$

$\begin{array}{lllll}\text { Onoclea Struthiopteris. Ostrich Fern } & .25 & 1.80 & 12.00\end{array}$

Osmunda cinnamonea. Cinnamon

Fern - -

regalis. Royal Fern__-____-_. $.25 \quad 1.80 \quad 12.00$

Polystichum acrostichoides. Christmas

Fern 

1

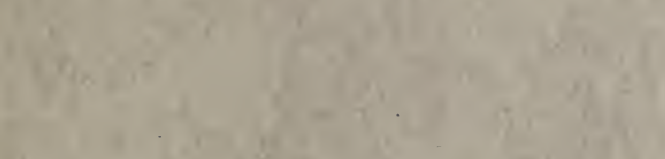

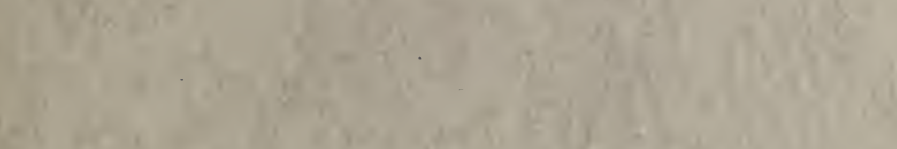

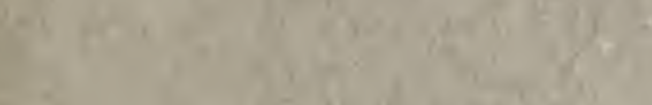

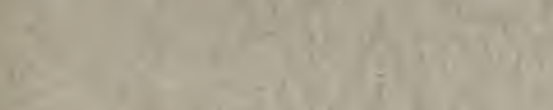

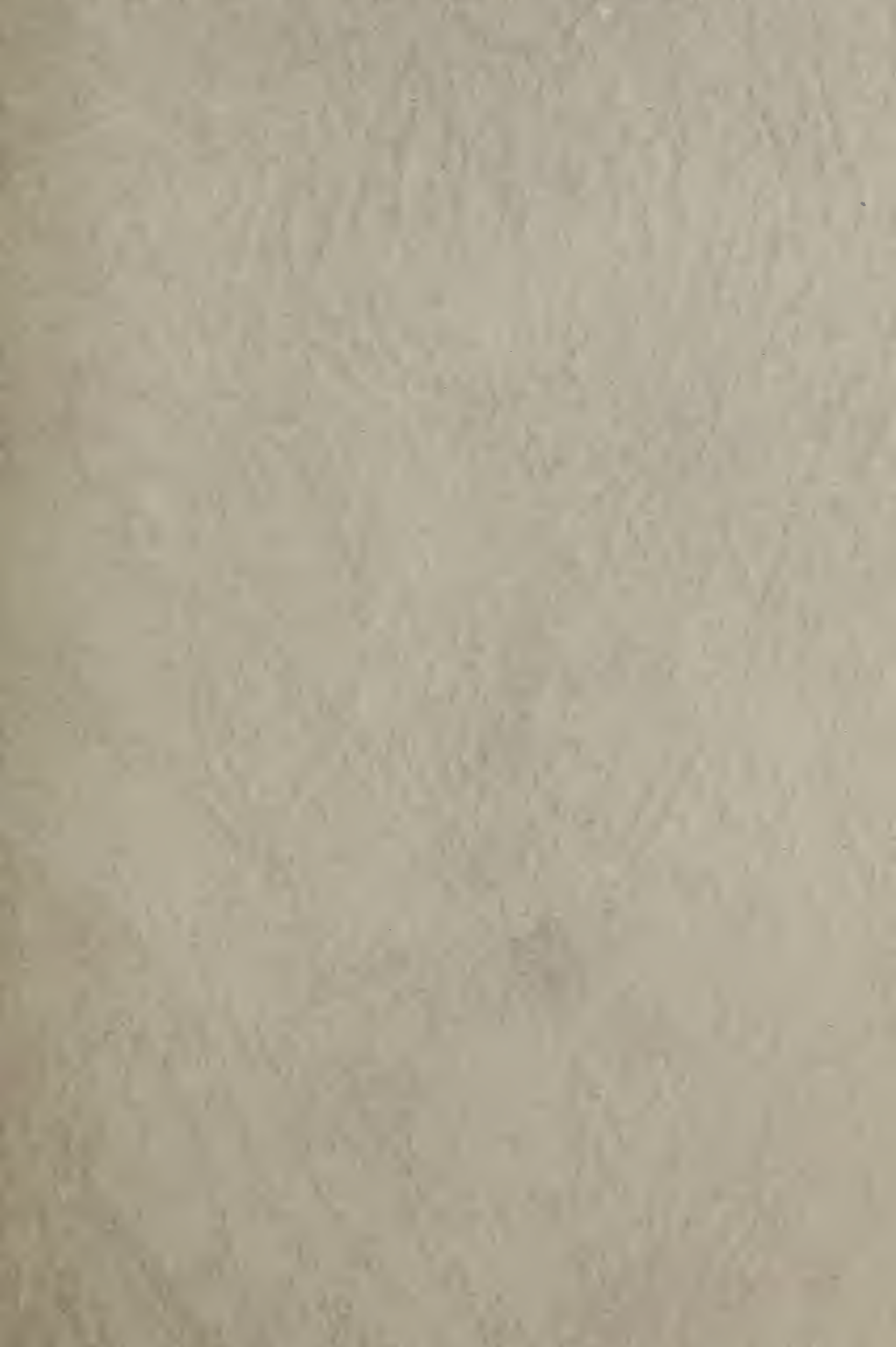


